\title{
عتبات النص فى رواية "أبيشج " كلأديب الإسرائيلى "دافيد شيتس" \\ دراسة تحليلية ذقدية
}

إيمان أيمن 
741 
قدف دراسة عتبات النص إلى فهم عناصر النص الداخلى بكل ما يحمله، من شخصيات

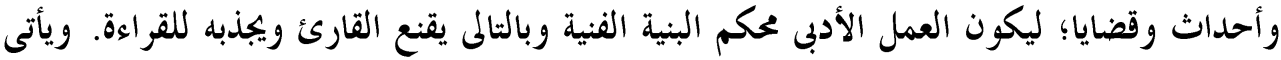
ضمن عتبات النصوص: العنوان، الغلاف، الإهداء، المدخل. ويتضمن هذا البحث عتبات النص فى رواية "أبيشج"، من خلال الدراسة التحليلية النقدية

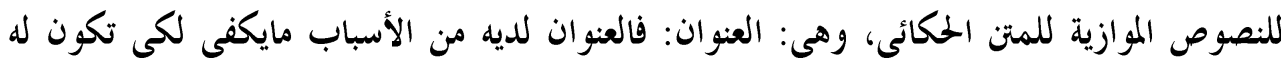

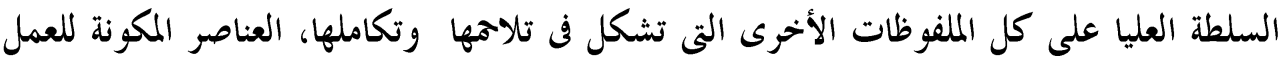

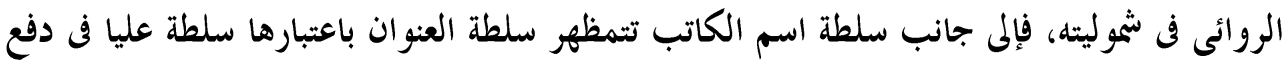

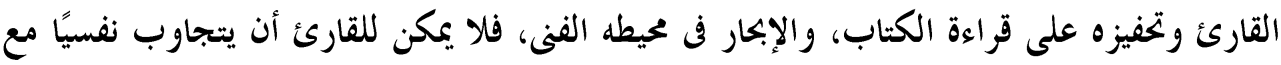
أى عمل أدلى بدون إلقاء نظرة أولية على عنوانه؛ فهو يفضى إلى الى النص كما أنى أن النص يفضى إليه.

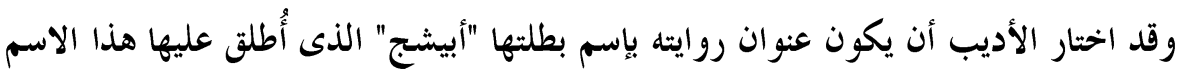

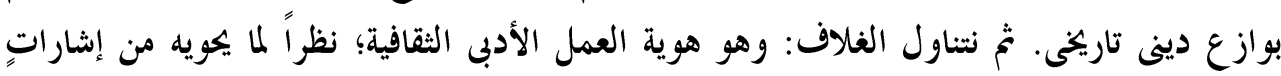

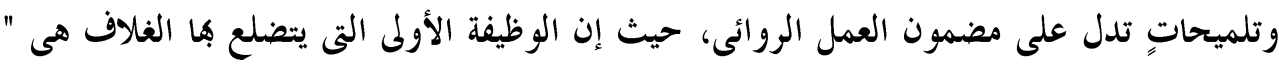

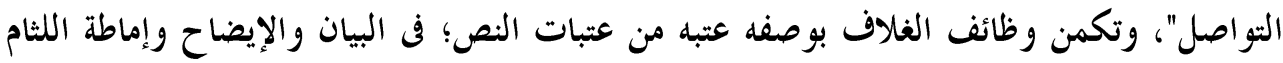

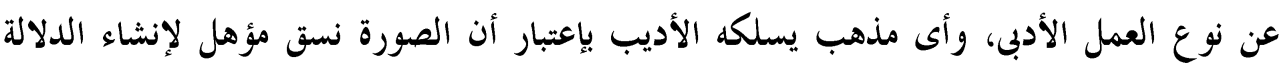

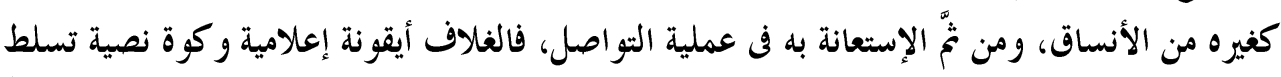

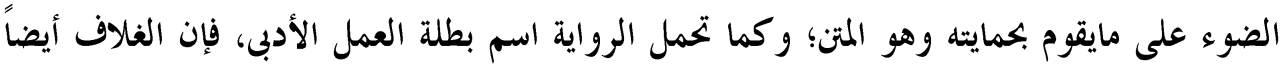

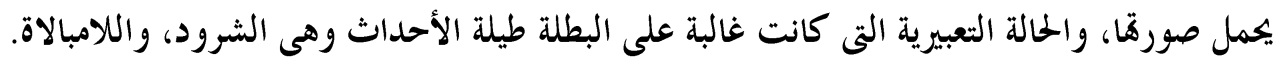

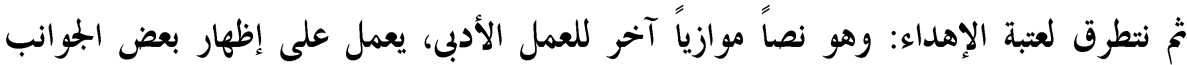

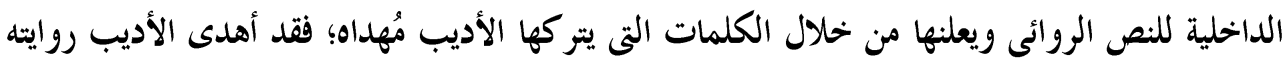

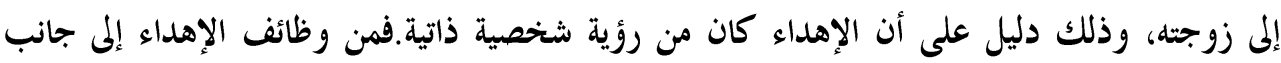

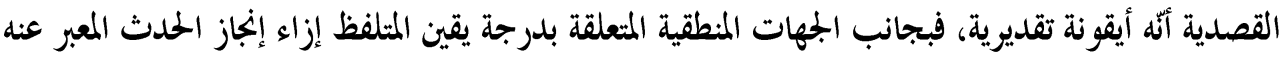

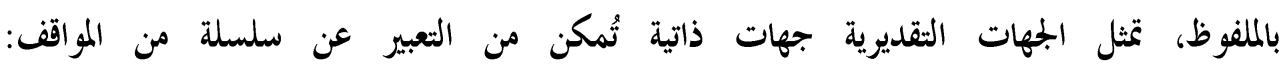
ابتهاج،سخط، أسف...بوسائل متنوعة، وخاصة تلك الوسائل النغمية، والمعجمية، والصرفية، والتركيبية. ويأتى المدخل: ضمن المتعاليات النصية؛ ذلك أن المدخل هو البوابة الرئيسة للعمل الداخلى لذلك يتحرى الأديب اختياره قبل صدور عمله. 


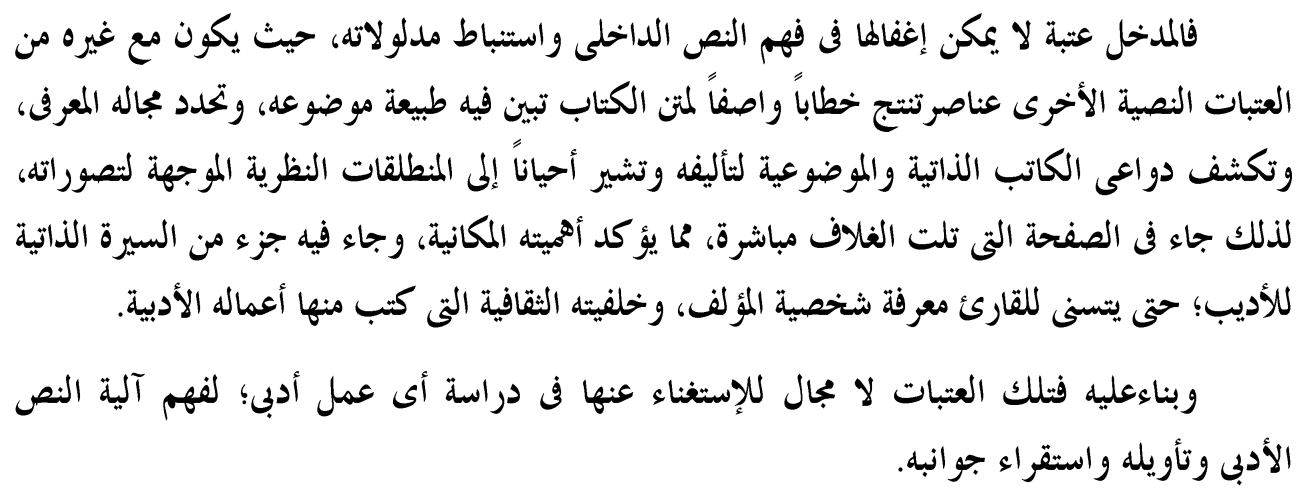

\section{Abstract}

This is Analytical and Critical Study about " The thresholds in David schütz's Novel Abishag", because the study of thresholds has become a necessity, especially in the modern Hebrew novel. The thresholds were represented in title, alerts appendices, margins, conclusion, introduction, cover, dedication. The study persents the relationship between thresholds and characters, and how much it useful to understand the literary content; cause it's a very important part of the narrative structure. The many of writers and critics the modern century are moving their hidden thoughts through the thresholds of texts.The discussions of this study come to discuss the function of the thresholds of lexical meaning texts, the title for example is giving basic information about the novel; specifically in this novel cause it's named "Abishag" the main hero in the novel, and the acts are based on her confessions. The cover is symbol has became a special version for each artistic the cover contains adesigner who designs the cover,and the cover here succeeded in his job and was in harmony with the narrative passages,expressed a true expression. The dedication thresholds, it indicates an appreciation from the dedicator to his audience and the sincerity of feelings towards the other.Finally, the introduction, it's function and the instruction,the notices, the margins,the openings, and it's relation to the novels under discussions. The introduction here came in the page that follows the cover directly indicates the spatial importance, it's an important threshold of the reader, cause it's a special interpretation through which the extrapolation of the internal narrative text, and came at the top of the portal name of the writer, and then the title of the novel, then came the settlement by mentioning part of the biography of the writer. And I hope, I was successful in achieving this study in a simple and clear way,cause the work in the field of semiology requires a lot of precision. 


\section{مقدمة}

عتبات النص هى الإرهصات الأولى التى تمهد لنا الدخول إلى عالم النص الداخلى بطريقة

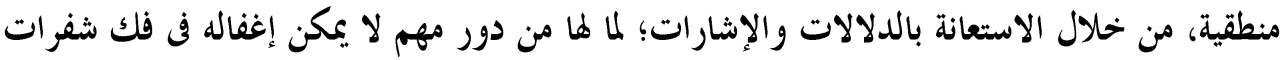

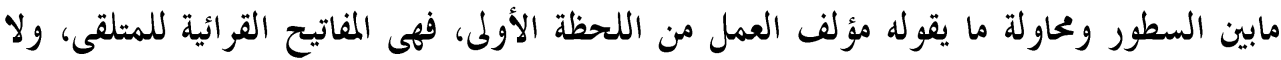

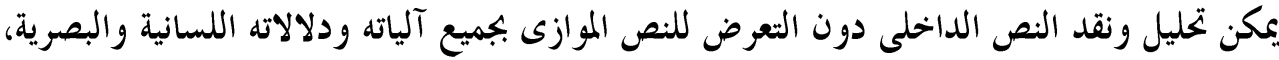

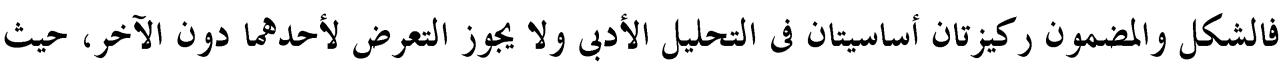

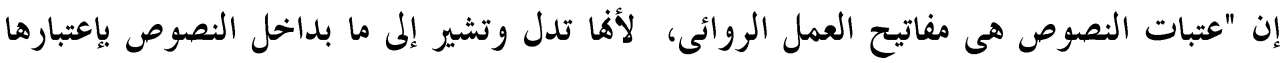

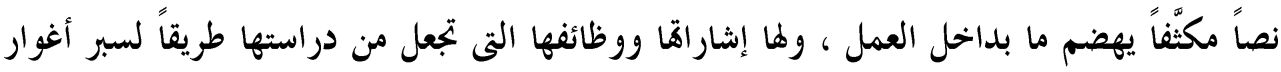

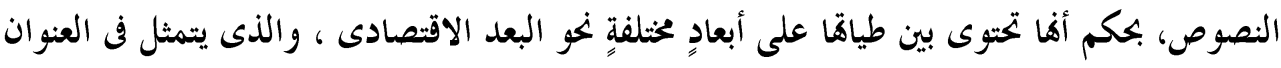

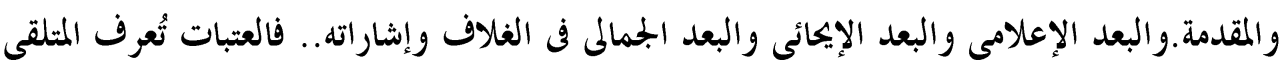

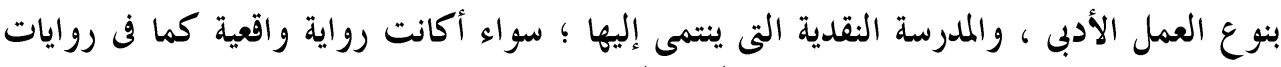

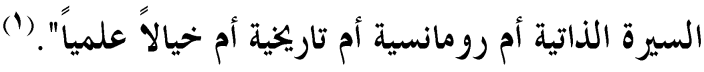
أولاً: تعريف عتبات النص: لغةً واصطلاحاً: إن التعريف اللغوى والإصطلاحى يعطى الكلمة مفهوماً أوسع، " فالمعنى اللغوى هو المعنى

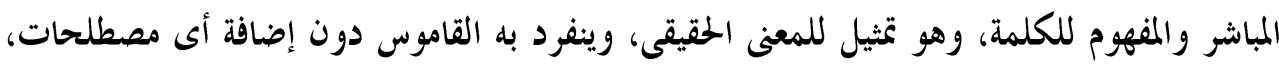

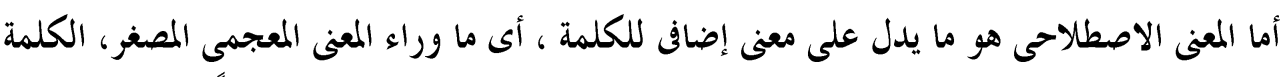

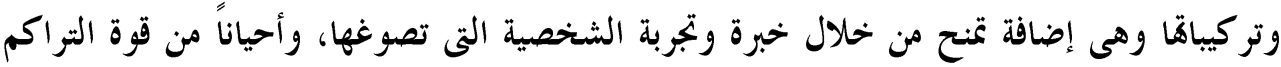

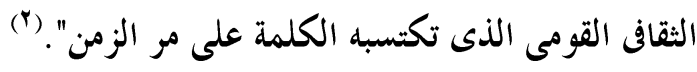

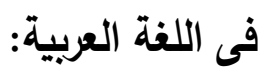

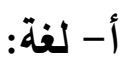

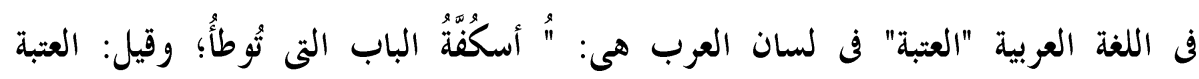

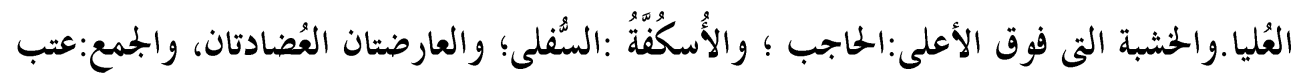

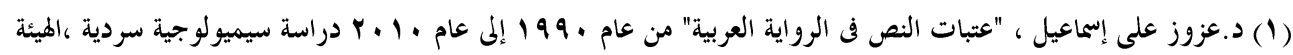

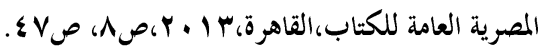

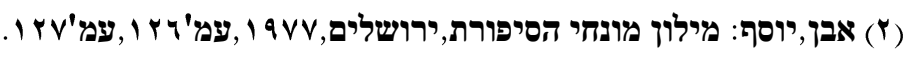


وعتبات.والعتبُ: الدَّرج وعتَّب عتبة:عتب الدَّرج:مر اقيها إذا كانت من خشب ؛ وكلٌّ مرقاةٍ منها

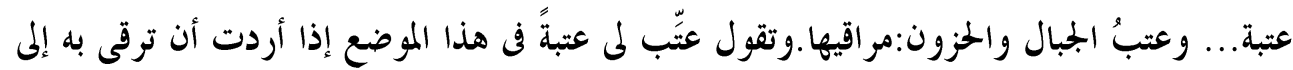

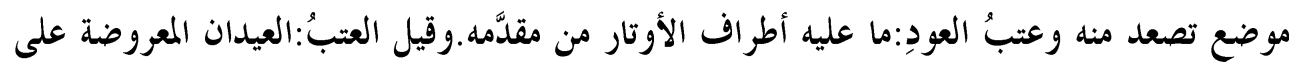

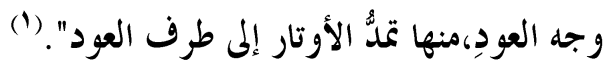

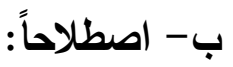

" العتبة فى النَّص هى الفاصل بين شيئين شنَّان مابينهما؛ بين الحارج بثقافاته المتنوعة والداخل

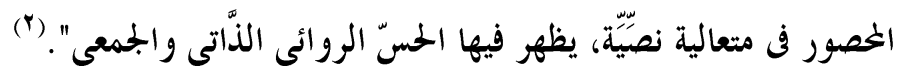

"وقد سميت عتبات النص هِذا المصطلح نسبة إلى عتبة البيت، فهى الأساس والركيزة التى يقوم

عليها النص". "(")

يتضح من ذلك أن تلك العتبات لم يتم وضعها بشكل اعتباطى، وإنما هى نصوص موازية للنص

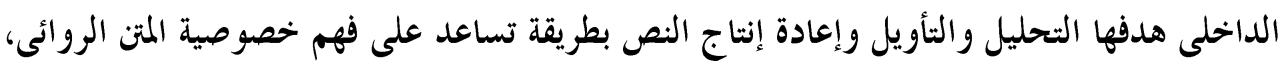

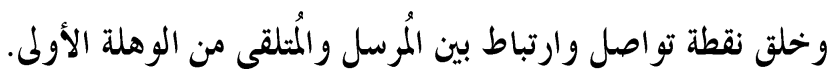

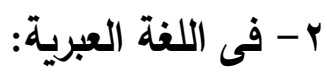
أ - لغة - ما

عتبات النص يقابلها فى اللغة العبرية المعنى الحرفى " ספים של הטקסט ".

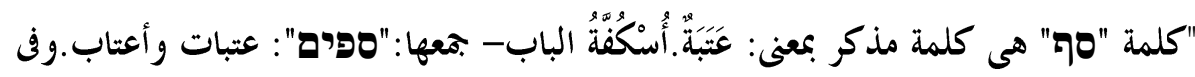

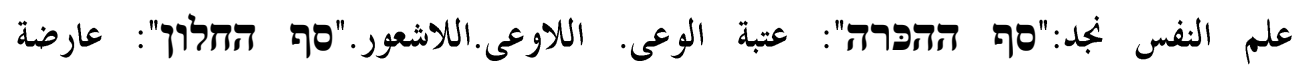
الثُبَّك. "ولاو אמות הספים": إهتزّت أركان الباب. كما نجد أن كلمة "عتبة" لها أكثر من معنى

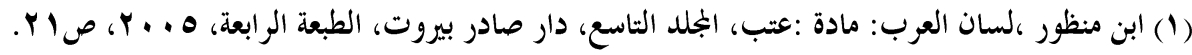

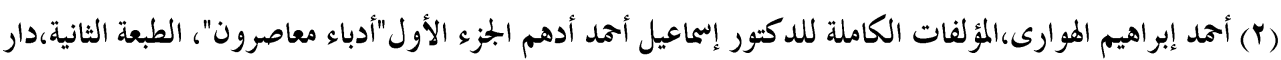

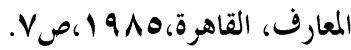

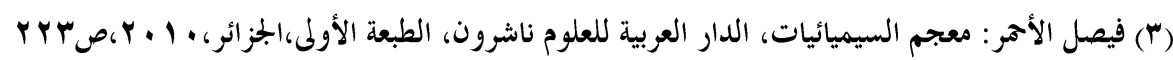




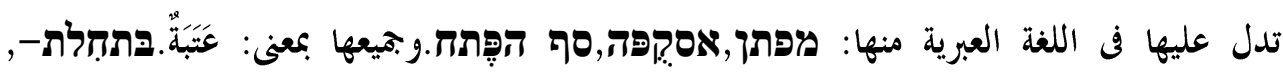

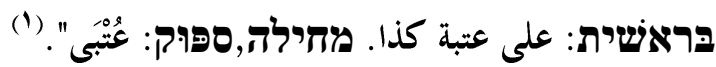

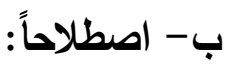

عتبات النص يقابلها في قاموس المصطلحات الأدبية العبرية لفظة " משפט

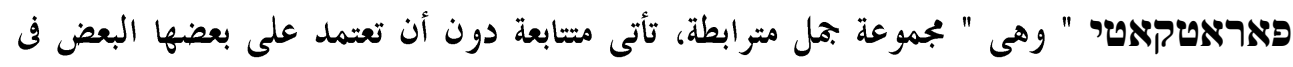

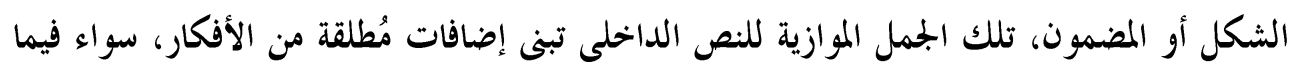

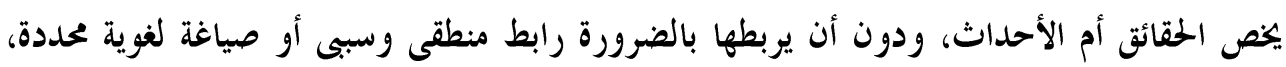

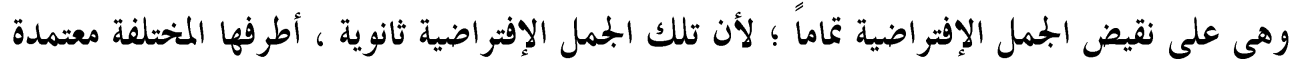

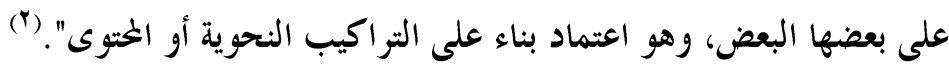

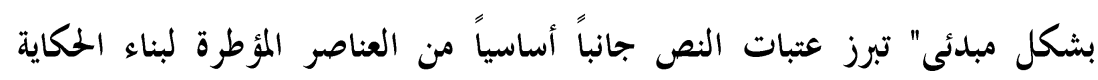

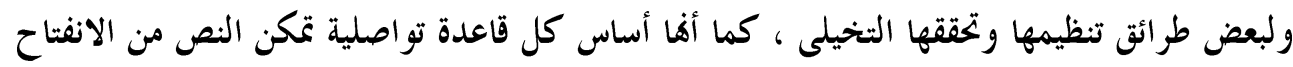

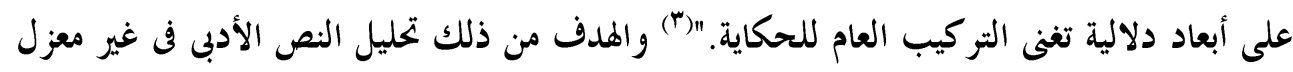
عن ظروفه الحارجية ، لأفا آليات الفهم والتحليل بالأبعاد المختلفة. ثانياً: دور عتبات النص فى بناء الثخصيات: ليس هناك شك أن العلاقة بين عتبات النص والشخصيات هى علاقة وطيدة؛ فعتبات النص هى الثى

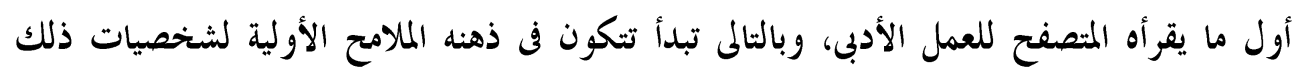
العمل، حيث إن تلك العتبات هى علامات استباطية تجعل القارئ على معرفة بطبيعة العمل الأدبى قبل العال

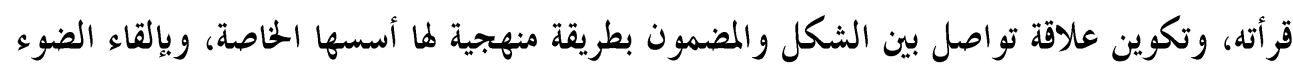

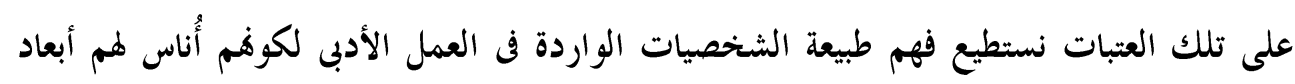
نفسية مختلفة.

(1) שגיב ,דוד: מילון שגיב ערבי- עברי.עברי-ערבי, הוצאת שוקן, ירושלים, תל-אביב,

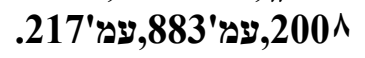

(5) אבן,יוסף: מילון מונחי הסיפורת,ירושלים,1977,עמ'141.

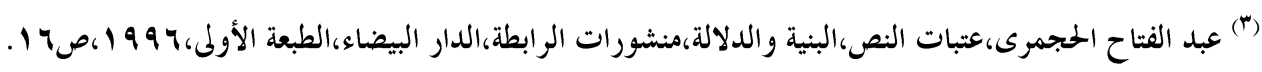


ولا شك أن تلك العتبات تلعب دوراً مهماً في بناء الشخصيات الروائية، ذلك " أن هدف دراسة عتبات النص هو معرفة حياة الإنسان وفكره و إنطباعاته في مجتمع من الجتيمعات من خلاءلال

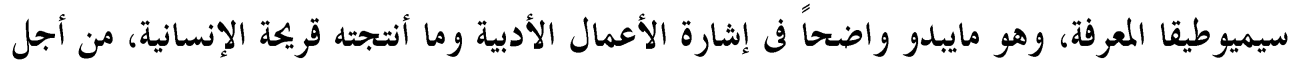

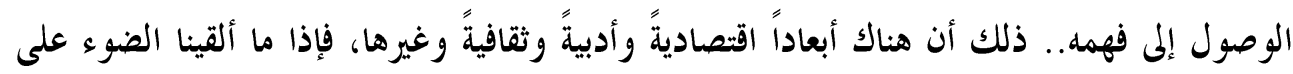

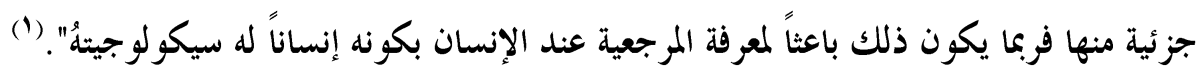
العنصر الأول: عنوان العمل الأدبى:

"لم تحظ عناوين الأعمال الأدبية العبرية إلا بالقدر اليسير من اهتمام الدراسات العربية التى

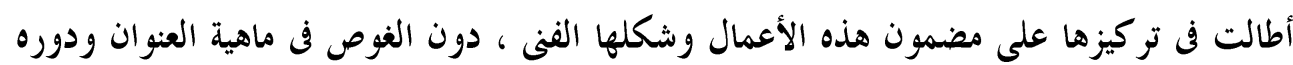

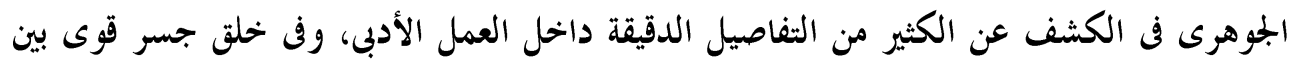

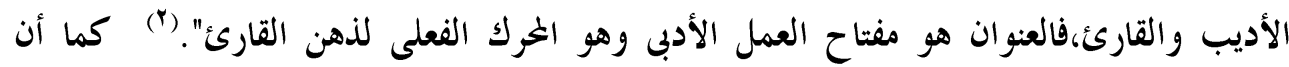

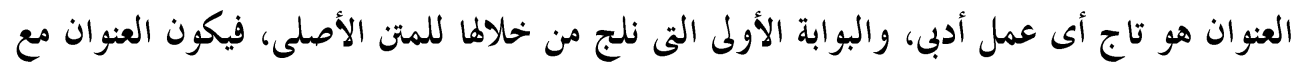

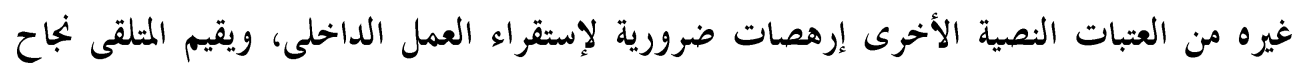

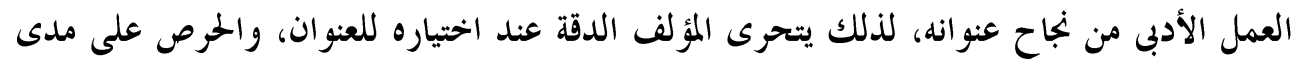

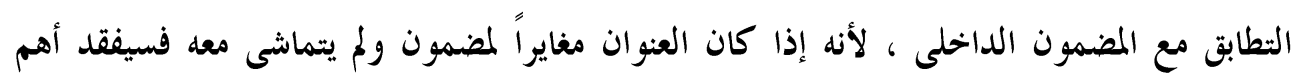
وظائفه على الإطلاق وهى التعيين والتفسير.

"فالعنوان هو الذى يظهر جليًا على رأس العمل الأدبى ، وهو الذى يُظهر ملامح شخصية

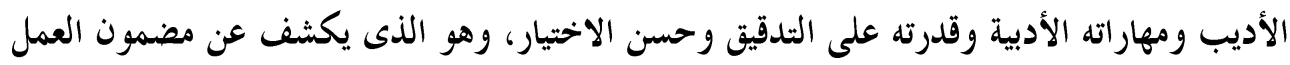

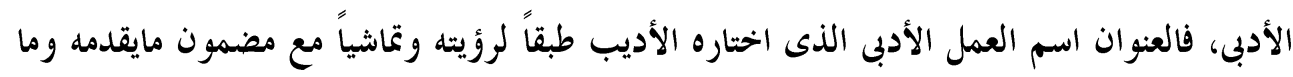

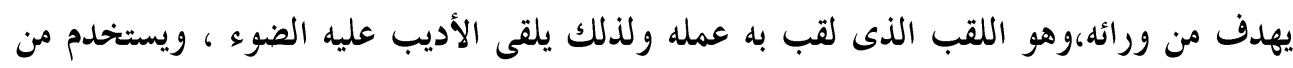

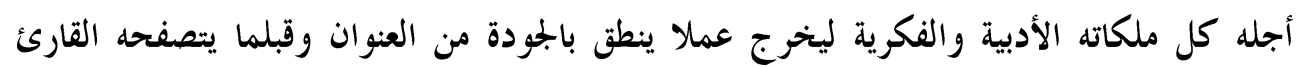

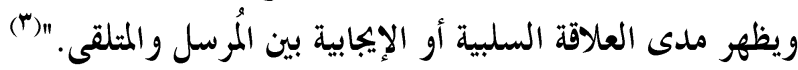

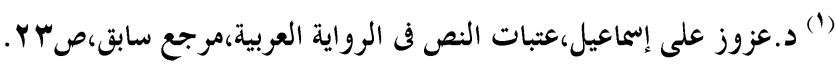

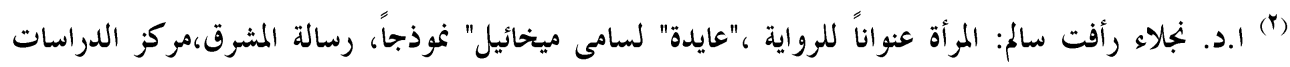

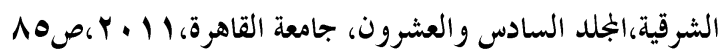

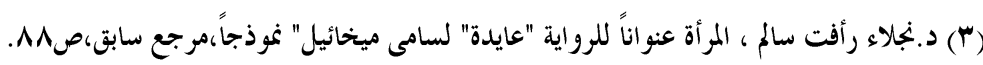


يحمل العنوان سمة الإغراء، وهى سمة مهمة من سمات العتبات النصية، وليس لزاماً على المؤلف اختيار عنوان عمله قبل الشروع فى كتابته، بل من أجل الدقة والتمحيص الختار مجُل الأدباء اختيار

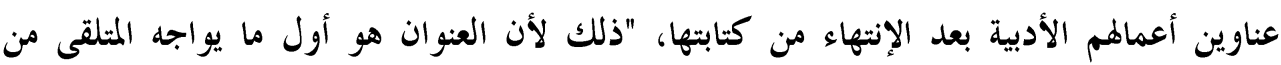

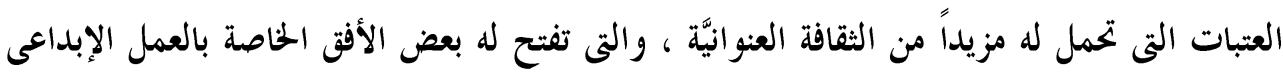

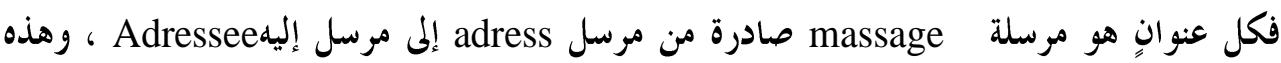

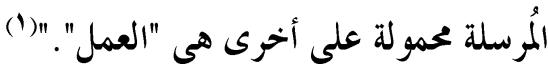

فى رواية " אבישג -أبيشج " للأديب الإسرائيلى " דווד שיץ - داثيد شيتس"، حمل

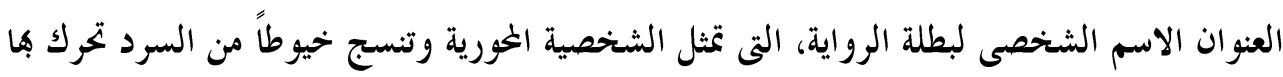

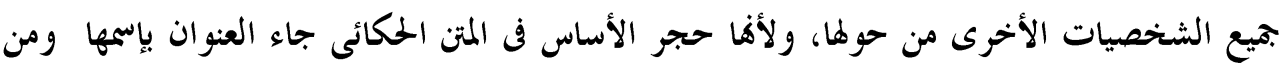

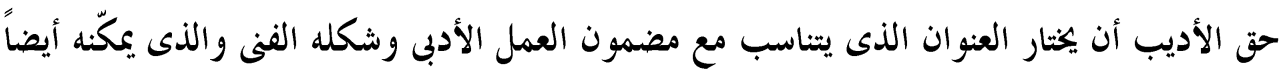

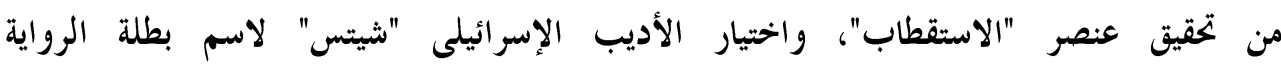

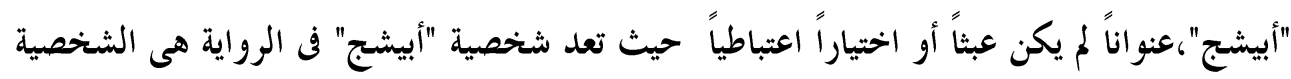

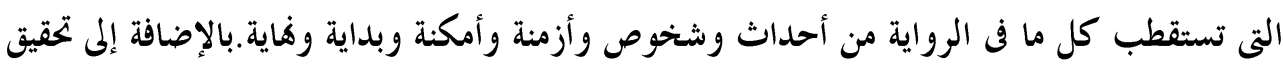
عنصر مهم من عناصر سيميائية العنوان، وهو عنصر الجذب واستقطاب القراء، فمن وظائف العنوان

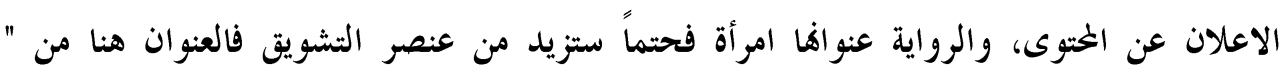

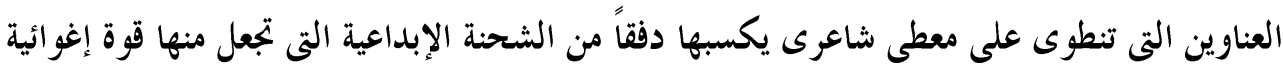
الجذب المثلقى، وجذبه للتجاوب معها، وبذلك يكتسب العنوان دلالات عميقة، تبعده عن التقريرية

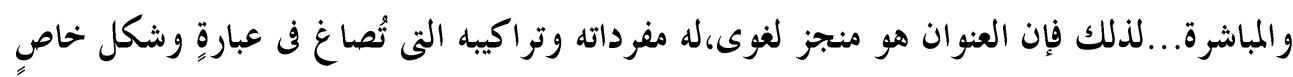

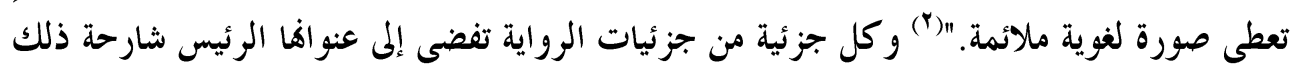

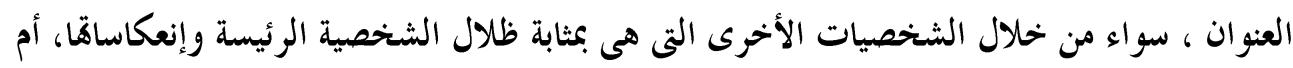

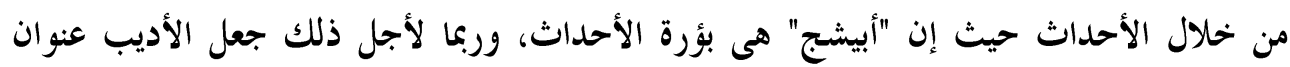

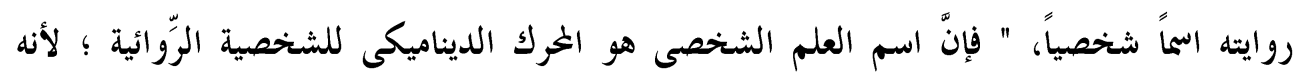

(1) د.محمد فكرى الجزار، العنوان وسميوطيقا الإتصال الأدب،، الميئة المصرية العامة للكتاب،القاهرة، 999 (19، 19.

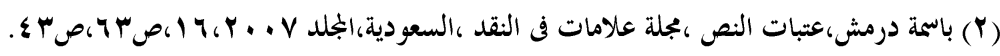




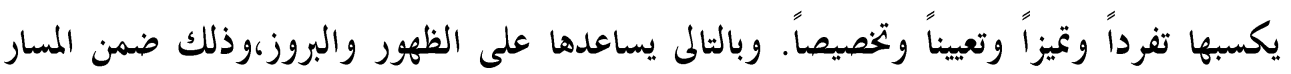

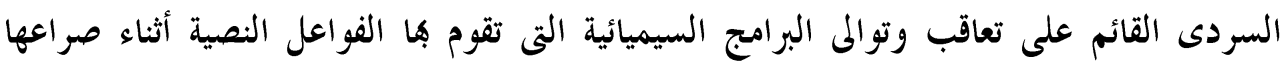

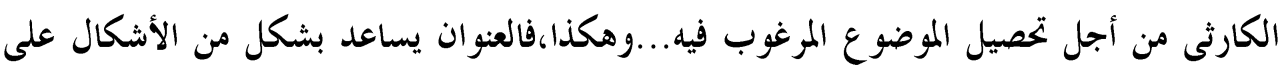

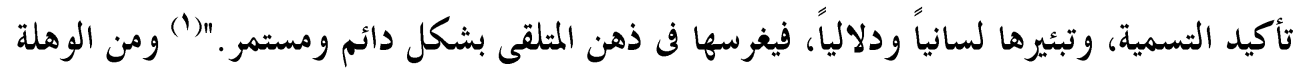

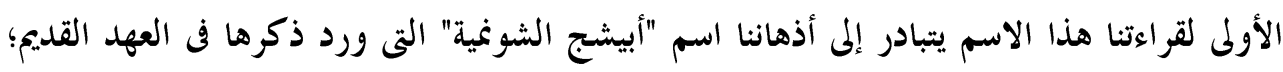

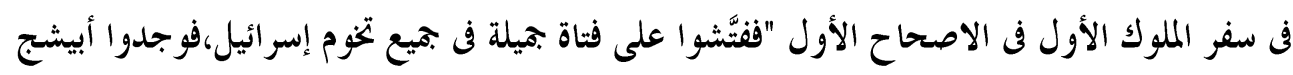

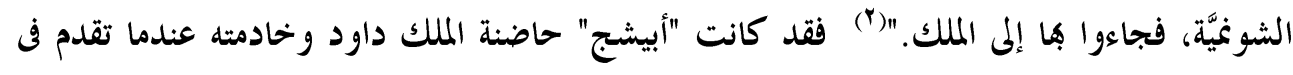

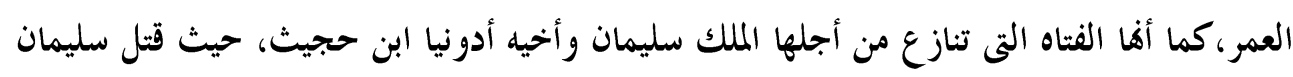

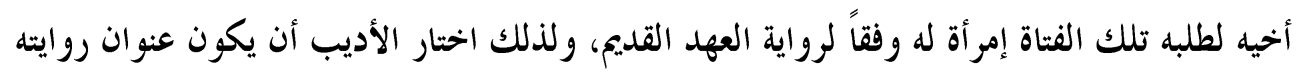

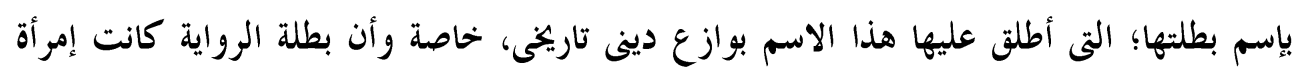

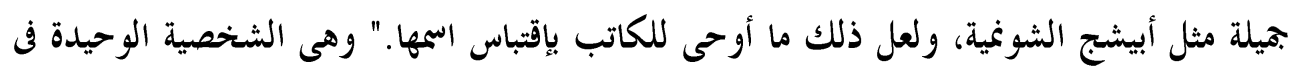

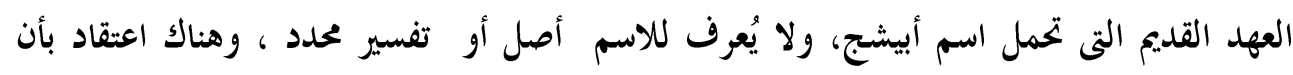

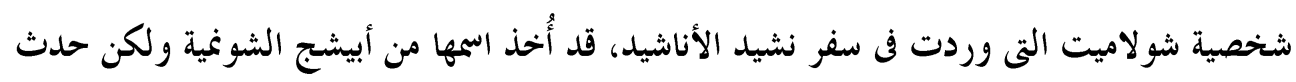

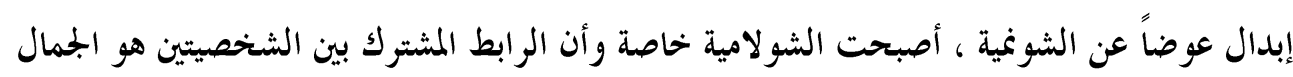

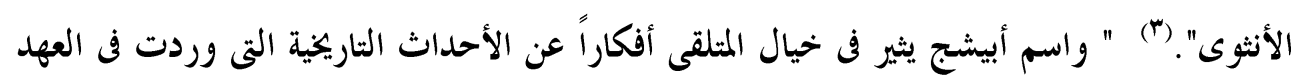

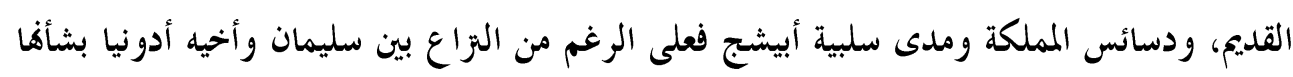

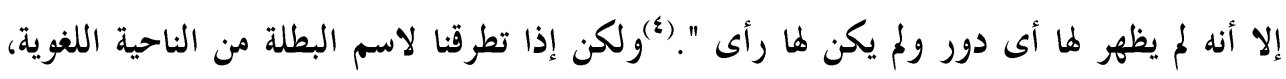

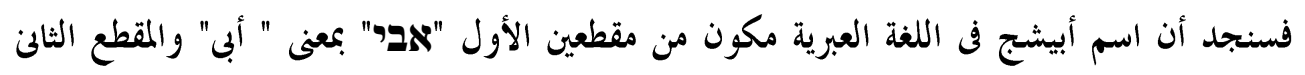

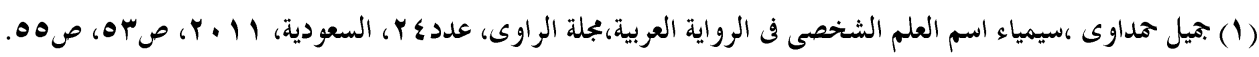

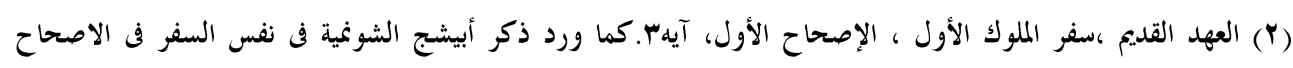

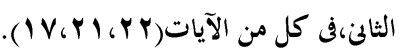
(") http://www.daat.ac.il/encyclopedia/value.asp?id1=3257

(צ) חדשות בן עזר,מכתב עיתי לילי הינש,מאת סופר נידה גיליון מסי גזו,תל אביב,כרך תעצוגות

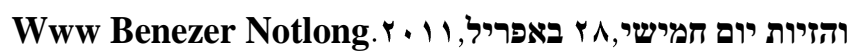
IV4 


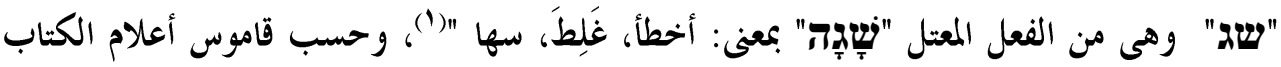

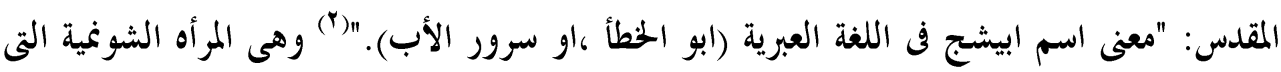

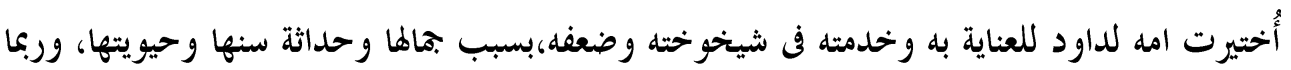
كان التفسير اللغوى هو الأقرب للصواب، حيث يرى النقاد أن"اسم الشخصية يعبر عن سلو كها". (") العنصر الثانى:غلاف العمل الأدبى:

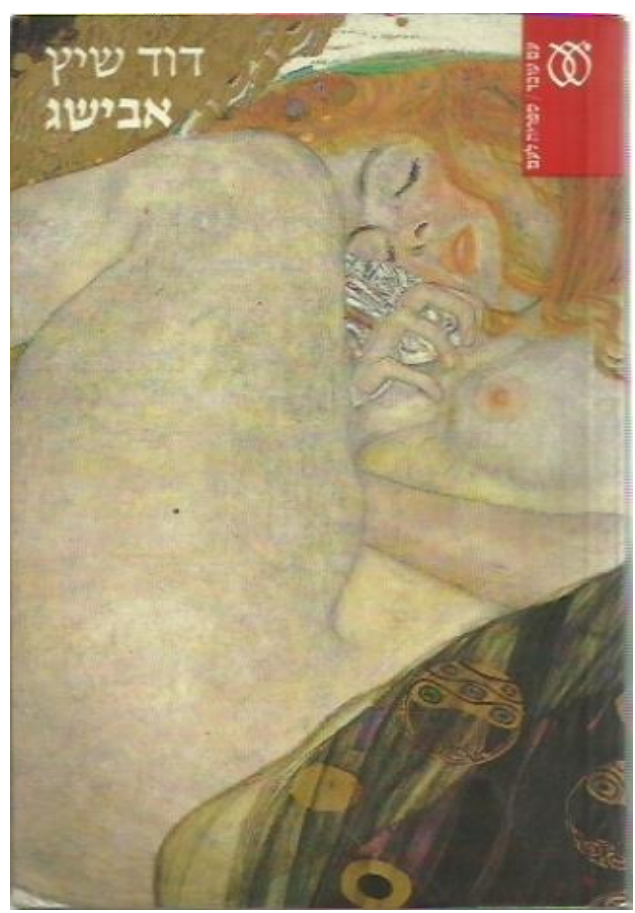

الغلاف هو ثلان أهم عتبة نصية حيث يحقق تواصل بصرى مع المتلقى، ويعدالغلاف من أهم

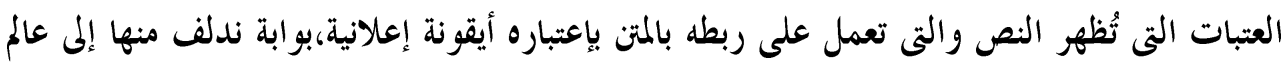

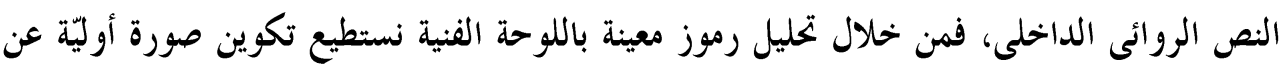

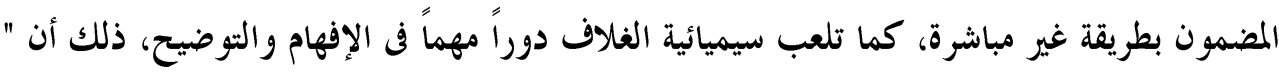

(1) שגיב ,דוד: מילון שגיב,ערבי-עברי, עברי-ערבי,עמ'ץ • 1. (Y) مكرم شرقى ،جُمان من فضة (قاموس اعلام الكتاب المقدس)، مكتبة الأخوة، القاهرة، ب +. Y، صع.

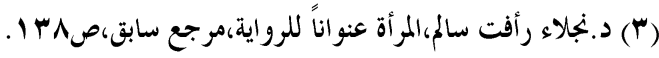


السيميائية هى الترابط الذى يبحث فى منظومة من العلامات، ووراء كل الظواهر البشرية التى تخيطها

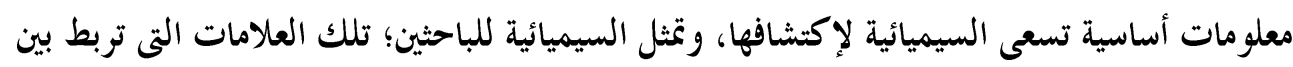

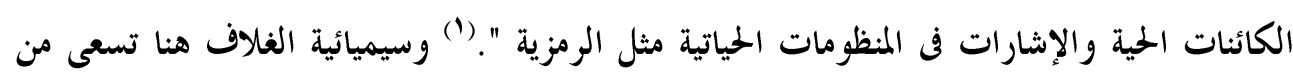

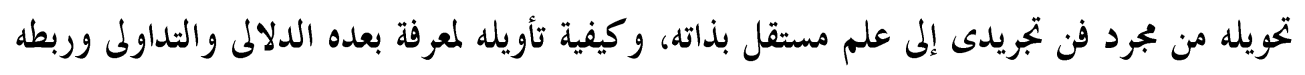

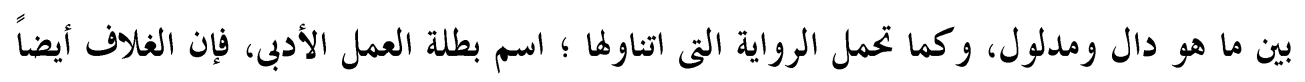

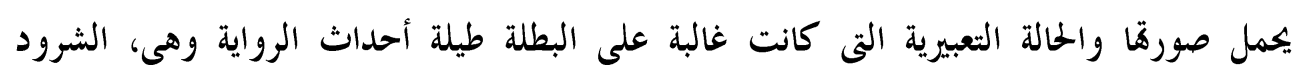

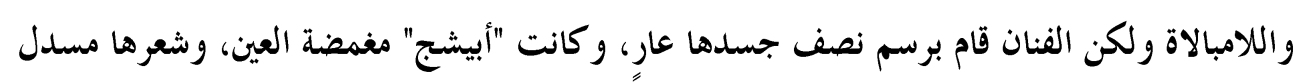

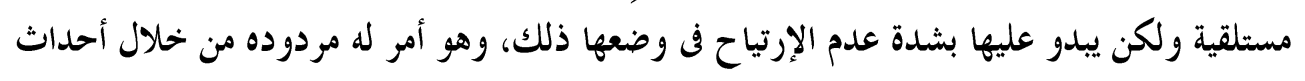

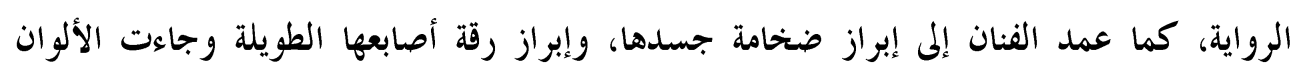

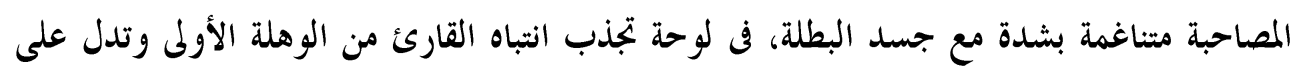

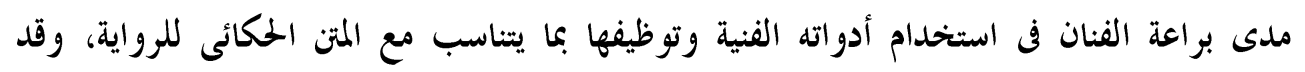

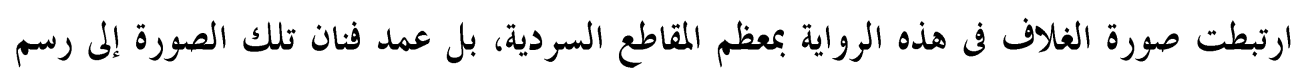

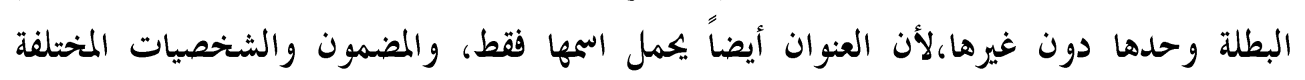

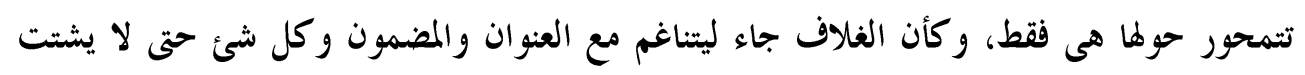
ذهن القارئ، ويجعله فى حيرة من أمره عند قراءته للعمل الأدبى، وتكتمل أركان العمل العاء الأدبى شكلاً ومضموناً، فوظيفة العمل الفنى تكمن فى كونه علامة توصيلية، حيث إن"التغييرات التى تحدث فئ في البيئة

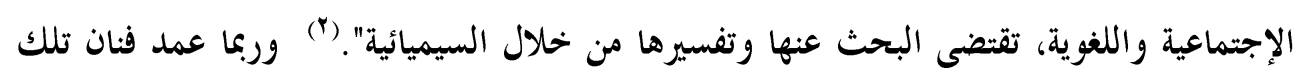

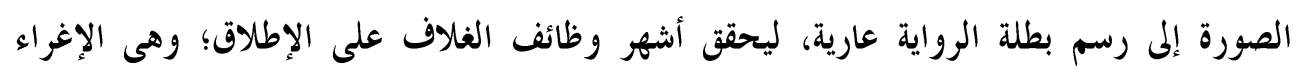

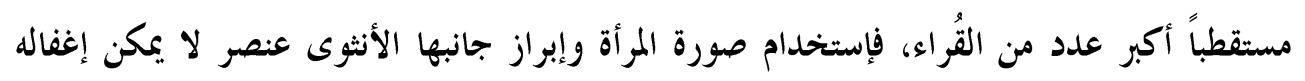

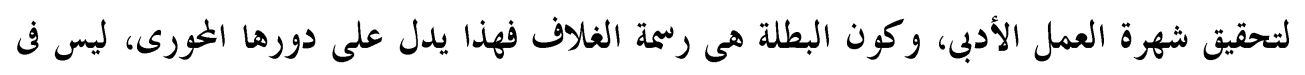

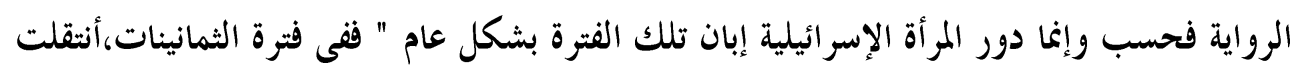

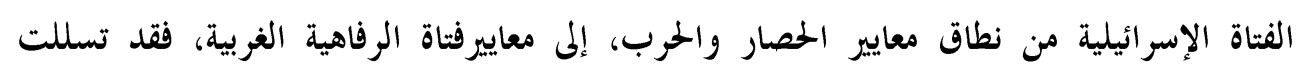

(1) וייפרייך : מושגי יסוד בסמאנטיקה ובסמיוטיקה, הספרות ג, גליון צ-ץ, ץV ו ו, עמ'ץ ו\&.

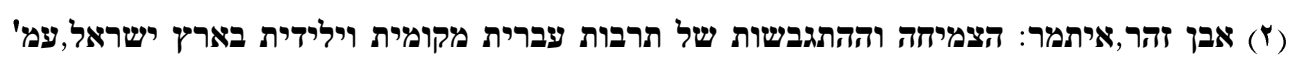


السياسة إلى كل موضع واستولت على معاقل لم يسمح لها من قبل بأن تكون موطئ قدم، ومن

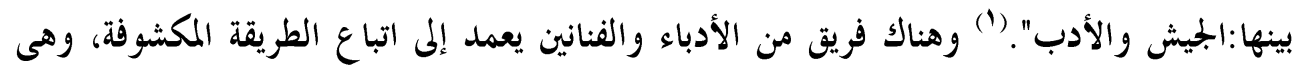

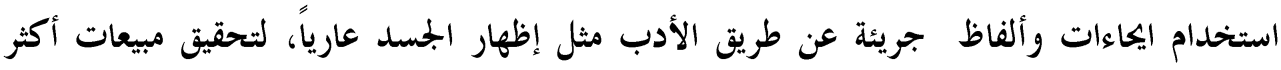

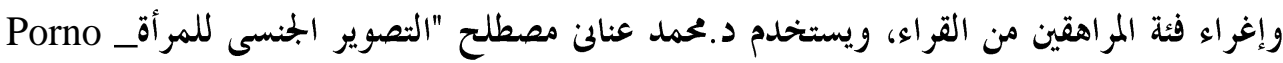

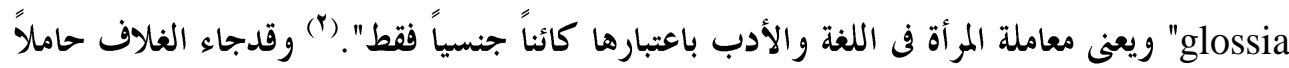
لشخصية بطلة الرواية،بنصف جسدها العارى وهى نائمة في وضع غير مريح، و كأن جسدها لم يأخذ وضعه الطبيعى فى الجلسة، فالبطلة منكمشة على ذاهّا مغمضة العينين، صورقا تنم عن كونها غير نائمة

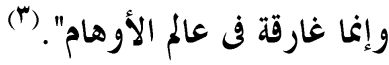

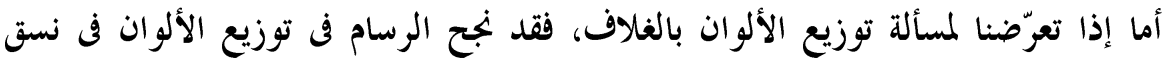

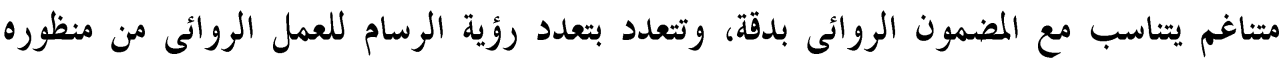

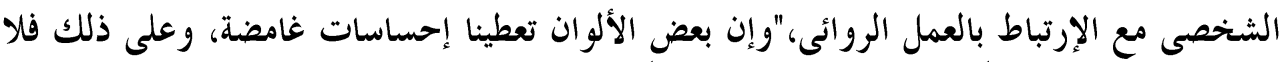

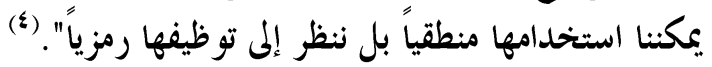

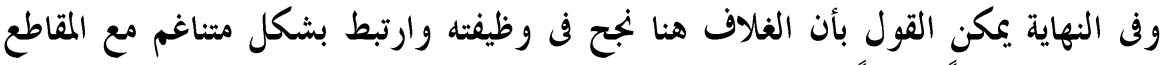

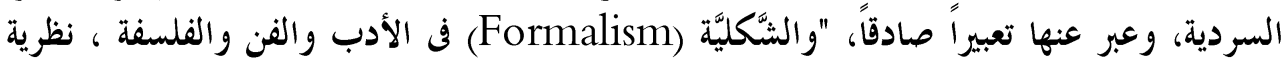

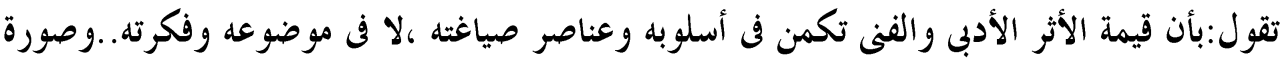

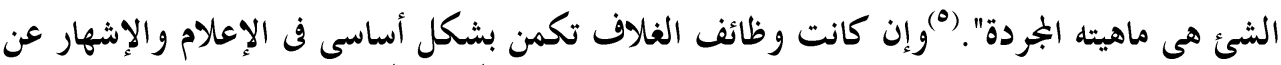

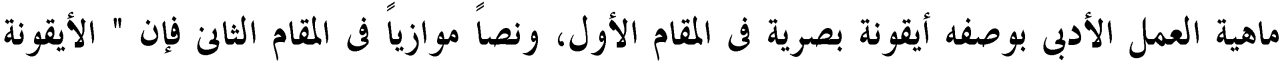

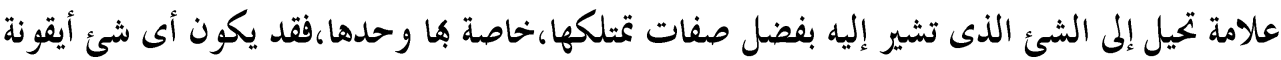

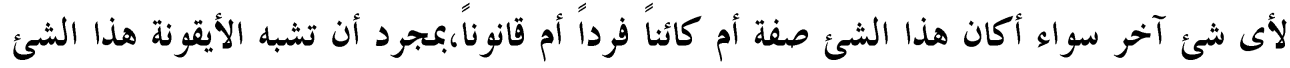

(1) אורן,יוסף,הקול הנשי בסיפורת הישראלית,"יחד",ת"א, ו.. ץ,עמ'יז. (T) د.بحمد عنانممعجم المصطلحات الأدبيةالحديثة، الشركة المصرية العالمية للنشر- لونجمان ،الطعة الثالثة، القاهرة،

$$
\text { VOD, T... T }
$$

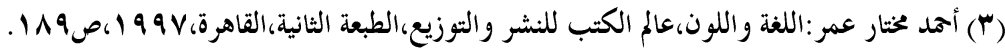

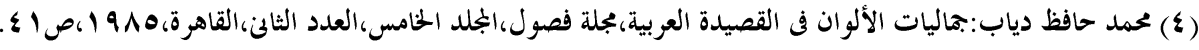
(•) د.راميل يعقوب،د.بسام بركة،د.مى شيخاني : قاموس المصطلحات اللغوية والأدبية،عرب،،انجليزى،ورنسى، الطبعة

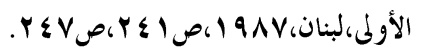


وتستخدم علامةً له". (") وبناء على ذلك فالغلاف لا غنى عنه فى تحليل الخطاب الروائى، لأنه ترجمة للعمل الروائى الداخلى ووسيلة اتصال بينه وبين المتلقى.

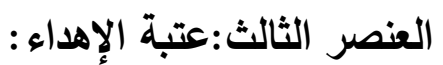
" إن الإهداء هو تقدير من الكاتب وعرفان يحمله للآخرين،سواء أكانوا أشخاصاً أم مجموعات

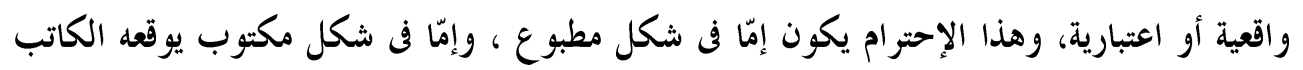
(؟) بخط يده في النسخة المهداة. بناء على ذلك فإن الإهداء هو عتبة من العتبات النصية التى لا يمكن إغفالها، أو تجاوزها

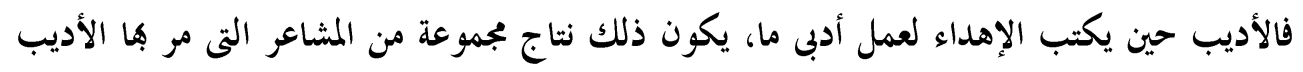

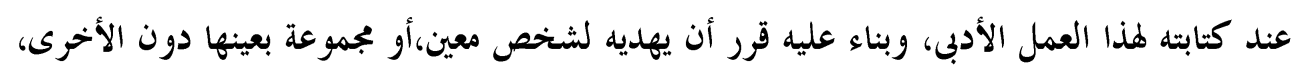

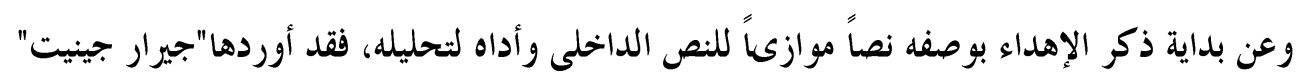

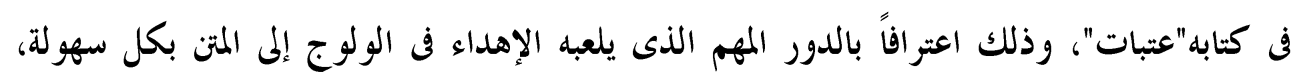

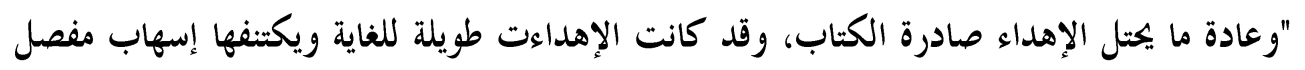

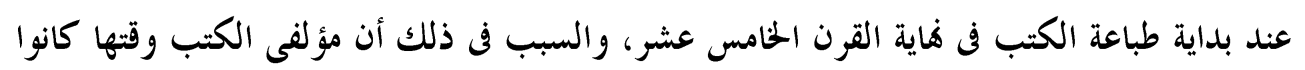

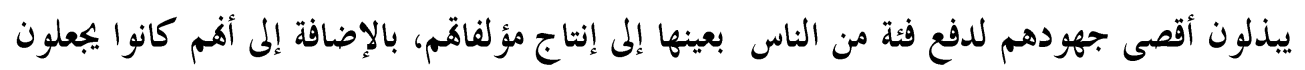

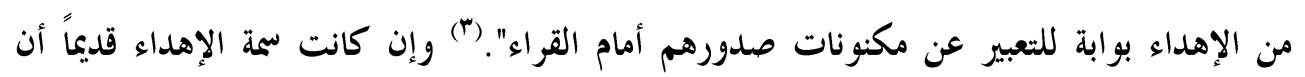

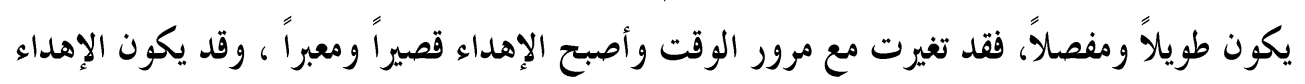

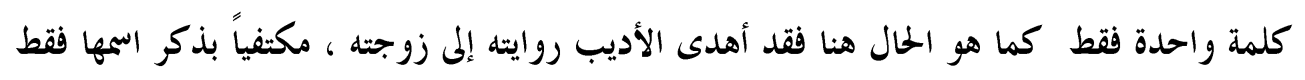

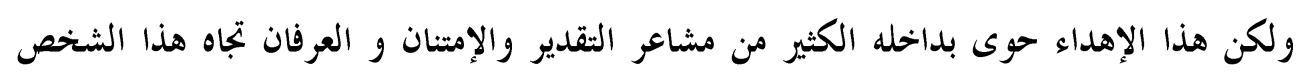

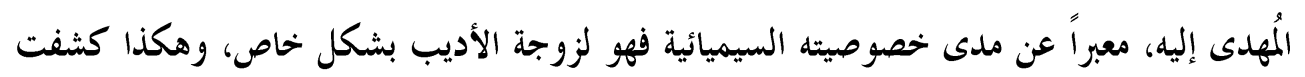

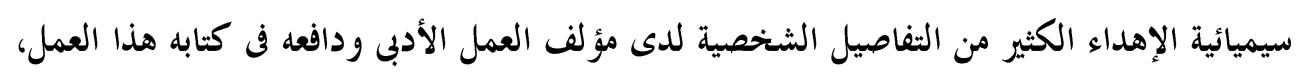

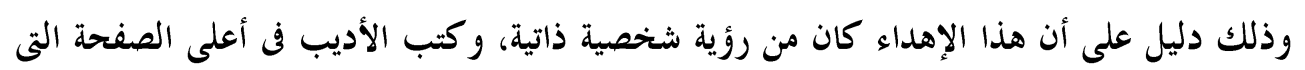

(1) سيزا اقسم،ونصر أبو زيد،أنظمة العلامات في اللغة والأدب والثقافة، مرجع سابق،ص آس.

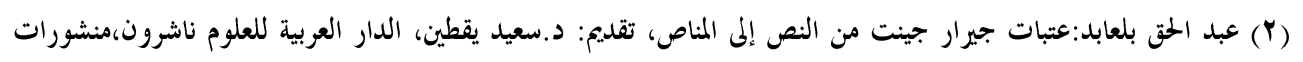
الاختلاف، الجزائر، م. . . r.

(3) Www.Shmoop.Com/Literature Glossary/Dedication. 
سبقت البداية مباشرة "לחמוטל"_" إلى حوطال"، وعادة مايكون الإهداء في الصفحة الثانية هذذه

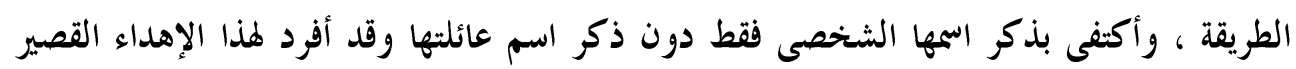

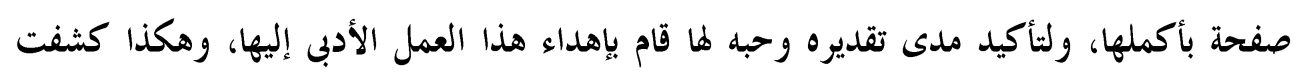

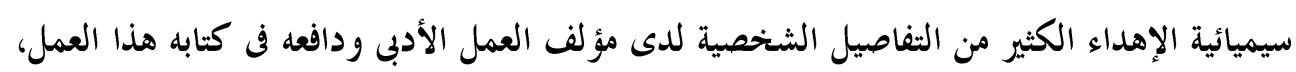

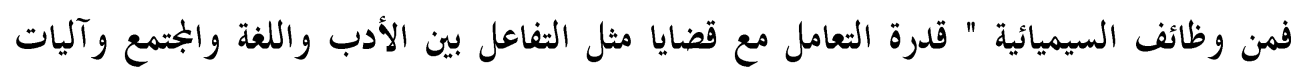

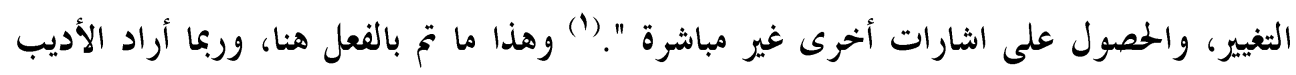

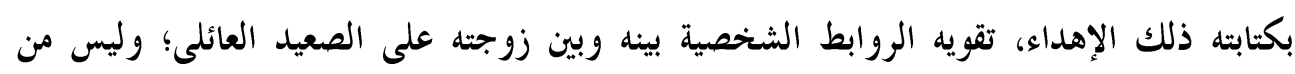

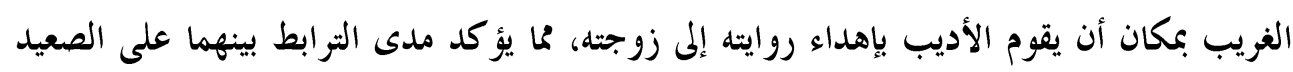

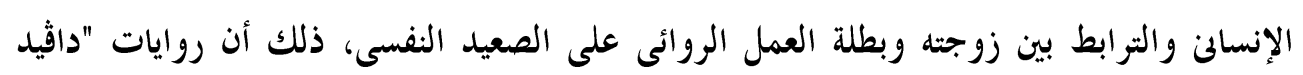

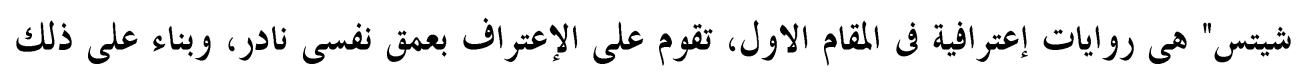

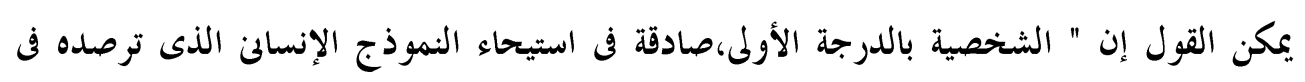

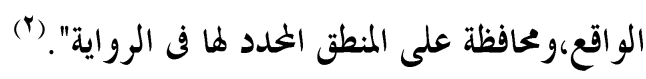

هكذا نجح الأديب في استجداء عنصر الإثارة من خلال هذا الإهداء، فُقبل القارئ على إقتناء

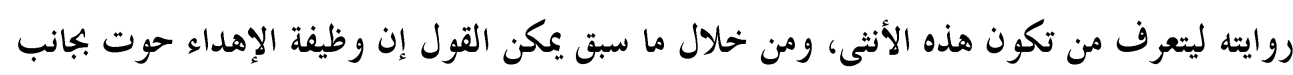
كوفا إشارة للتواصل ومحاولة فهم النص، وظيفة خصوصية من قبل الأديب لأحد أفراد أسرته، محاولاً

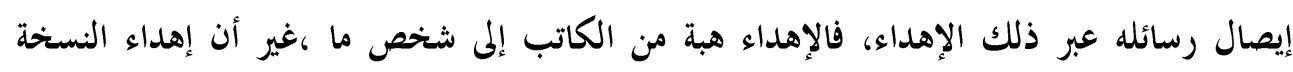

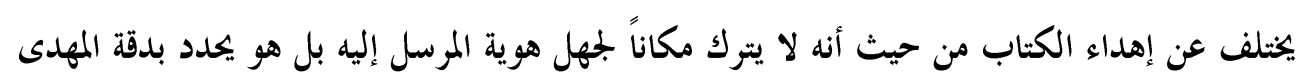

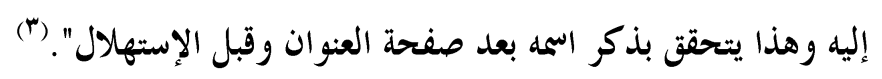
أما عن وجود علاقة بين إهداء الكاتب الرواية لزوجته والرواية نفسها، فيوجد بين بطلة

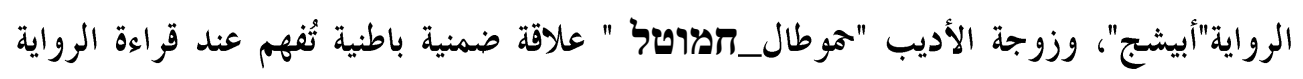

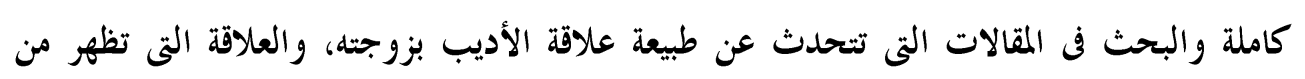

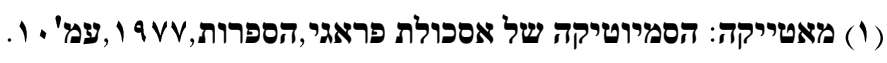

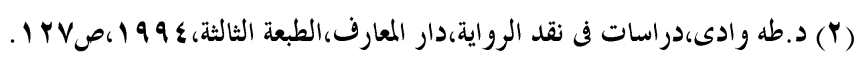

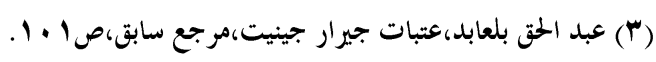


خلال تحليلى للمقالات التى كُتبت عن الأديب، ومن خحلال قراءة المتن الروائى هى حب الأنثى بوجه

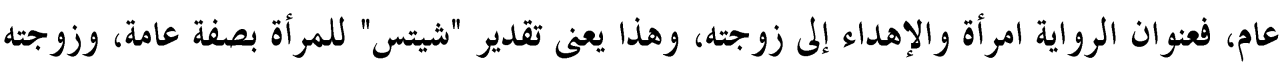
بصفة خاصة.

والإرتباط هنا بين المتن والإهداء يكمن في الأنثى سواء أكانت تلك الأنثى زوجته أم أى إنسانة

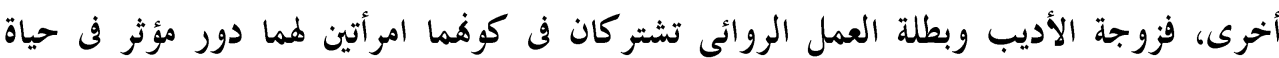

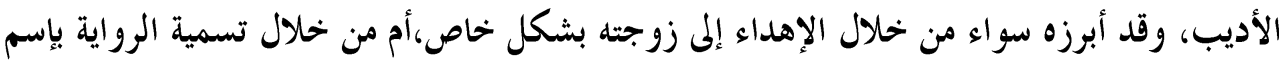

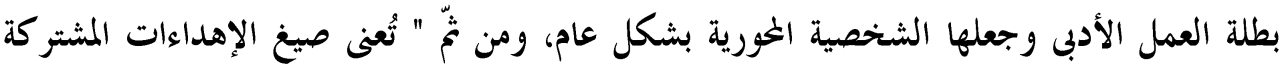

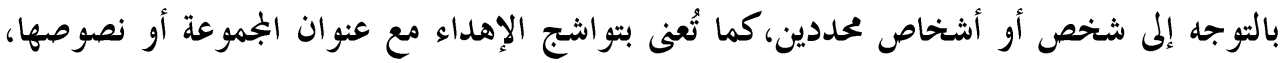

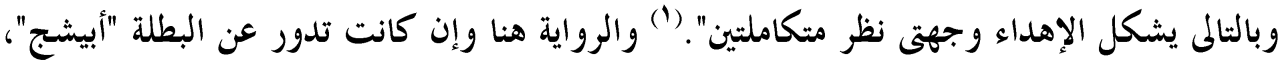
ولكنها ثُروى بواسطة الراوى الذى يقص حكايتها المعقدة، وهذا دليل قوى على أن الرواية تدخلت

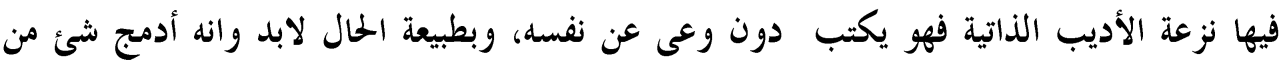
حياته الخاصة والأسرية في هذه الرواية، فجعل زوجته تتشارك البطلة في شخصيتها بما يحب ويكره وهذا ما يفسر إهدائه الرواية لها،وقد أكدت المقاطع السردية على مدى عمق المشاعر التى يكنّها البطل(الأديب)،للبطلة(زوجة الأديب) وهذا يعكس وجهة نظر الأديب في كتابته الإهداء وتوظيفه إياه

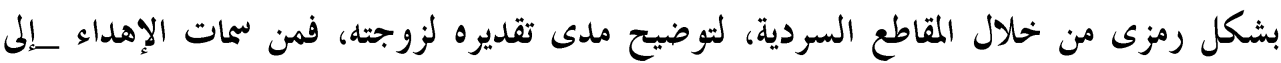
جانب القصدية_أنه أيقونه تقديرية، فنجد أنه "بجانب الجهات المنطقية المتعلقة بدرجة يقدئ مدين المتلفظ إزاء

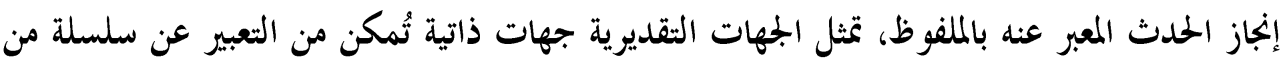
المواقف:ابتهاج، سخط، أسف. بوسائل متنوعة، وخاصة وسائل نغمية، و ومعجمية، وصرفية

(ن) وتر كيبية"

وإن كان الأديب قد دفعته تلك المشاعر من التقدير والوفاء إلى كتابة ذلك الإهداء إلى زوجته فعند البحث عن تلك الزوجة والإطلاع على وجهة نظرها في شخصية الأديب، نجد عند سؤ الها في

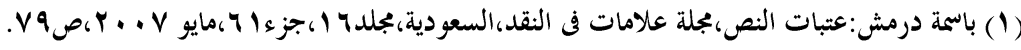

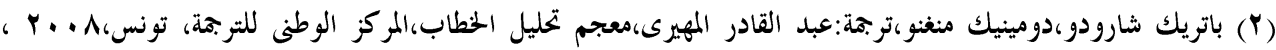


أحد المقالات عن ماهية الحياة الزوجية مع " دايثد شيتس" تقول مموطال : " كانت الحياة مع دايثد رائعة ومعقدة، ليس من اليسير أن تعيش مع شخص له ماضى صعب، وسيزة ذاتية قاسية، أثرا في

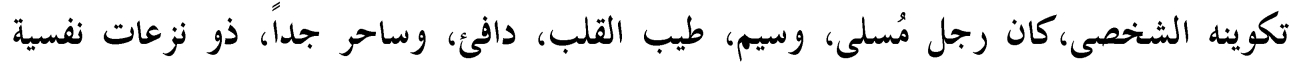

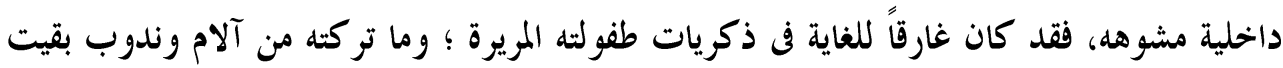

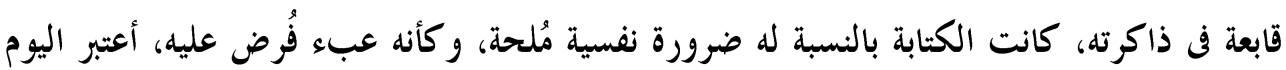

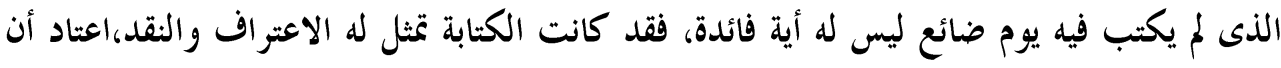

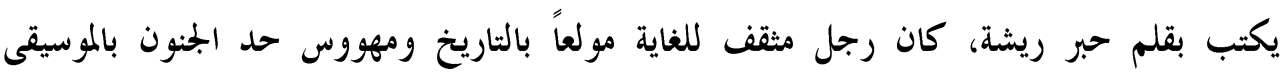

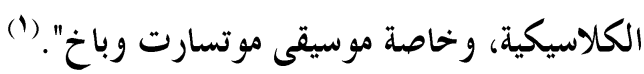
فالإهداء عتبة غاية فى الأهية، لابد من تحليلها والوقوف عليها فهى ليست حشواً زائداً كما يظن البعض، وأهمية الإهداء تكمن فى كونه أداة لإضاءة النص الداخلى وفهم آلياته ودلالثه، من خلال

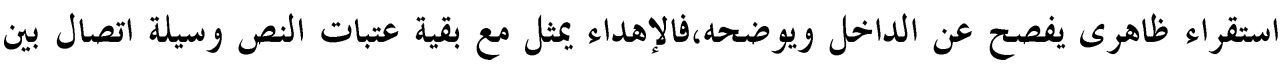
الشكل الروائى ومضمونه وربطهما ببعضهما فى سياق أيدولوجى، ليتمكن القارئ من فهم أبعاد العمل

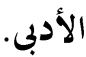

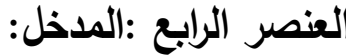

جاء مدخل الرواية في الصفحة التى تلت الغلاف مباشرة مما يدل على أهميته المكانية، فهو عتبة

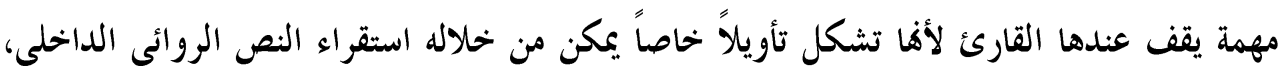

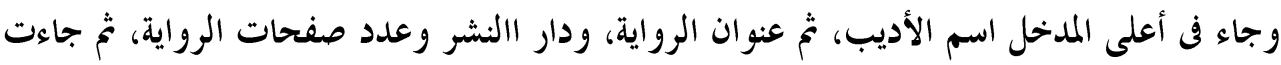

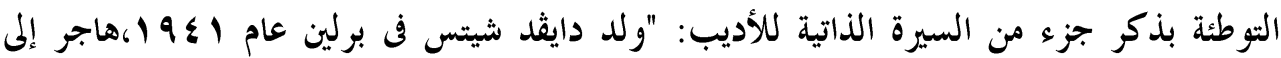

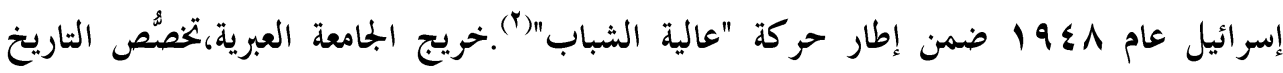

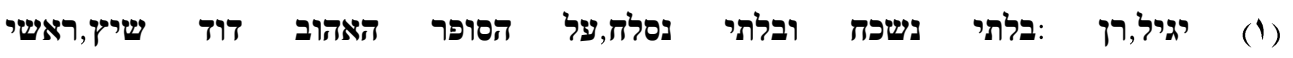

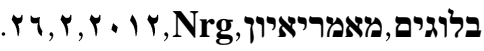

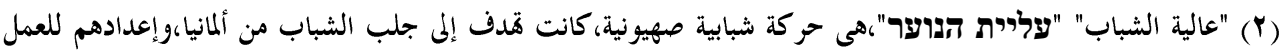

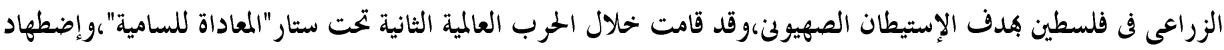
هتلر لليهود في ألمانيا. 
والفلسفة.يعمل فى هيئة الأفلام السينمائية الإسرائيلية.نشر حتى الآن أربعة كتب: "العشب والرمال"، "الفرصة الأخيرة" ،"سأنتظر للأبد"، "سوسنة بيضاء وسوسنة حمراء" "(1).

فقد جاء التعريف بالأديب مقتضب جداً، وكون المدخل جاء بتعريف الكاتب فذلك له عدة

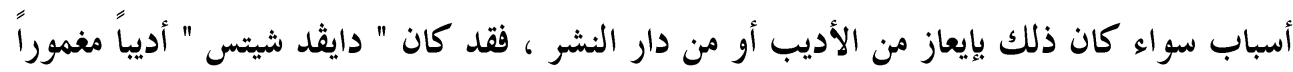

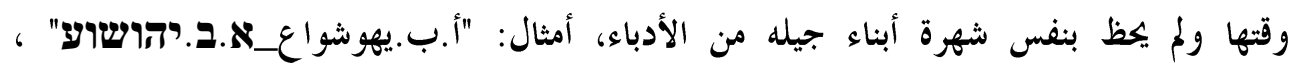

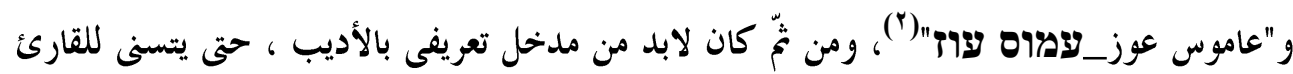

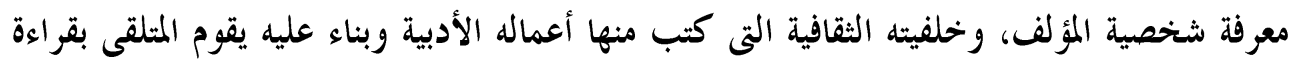

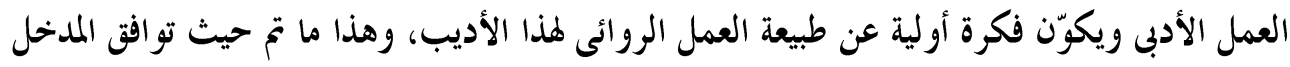

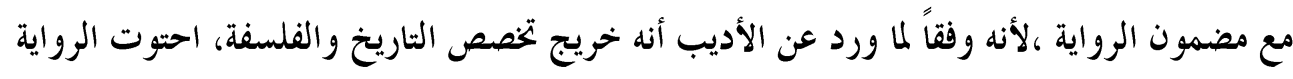

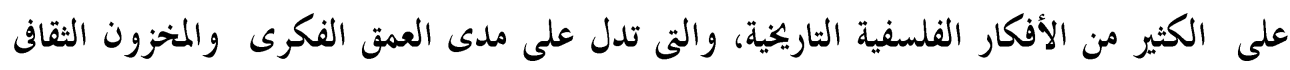
لمؤ لفها .

وربما أراد الأديب أن يخلّد جزء من سيرته فى أعماله الأدبية كافة، فقد كتبت سيرته الذاتية فى

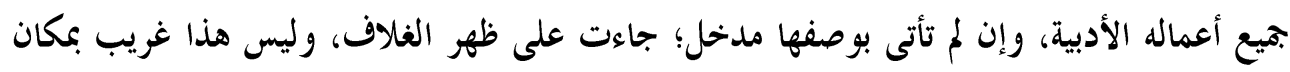

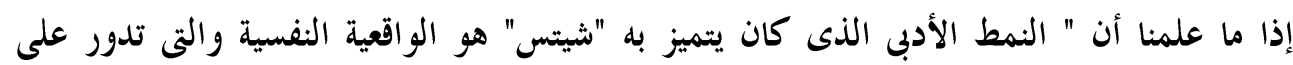

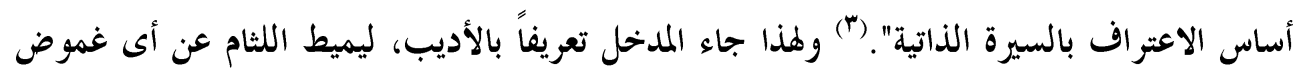
من الممكن أن يكتف العمل الروائى أومؤلفه.

(1) שיץ, דוד ,אבישג,עמ'ו.

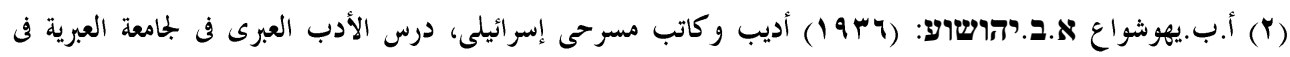

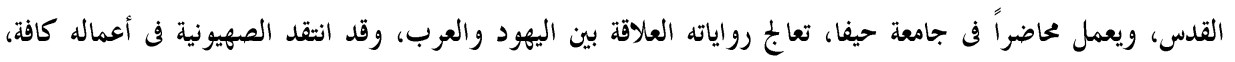
وحظى بشهرة واسعة في الأوساط الأدبية.

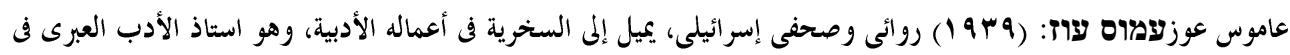
جامعة بن جوريون بئر سبع، وهو أديب ذائع الصيت فـ إسرائيل.

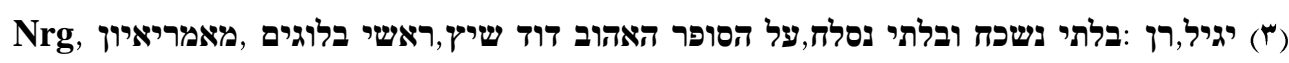
.YY,Y,Y,IY, 


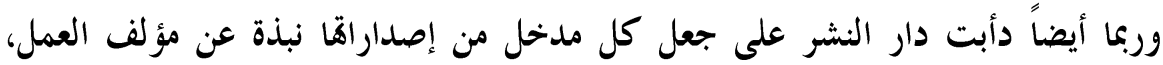

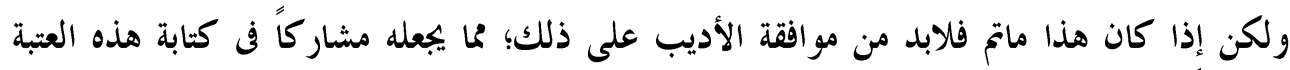
و ومسؤلاً عنها.

بوضع هذا التعريف كمدخل للرواية،عوّل على مضموفا بطريقة تجعله مدخلاً صحيحاً للرواية

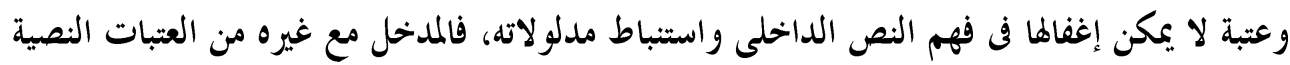

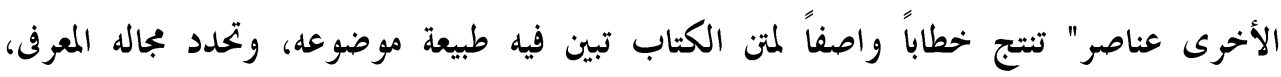

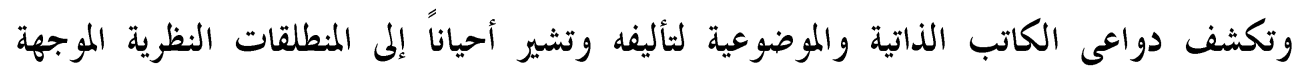

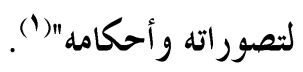

وربما أراد الأديب أن يعرّف القارئ؛ بماهية العمل الأدبى دون مقدمة أى يدخل فى معرض

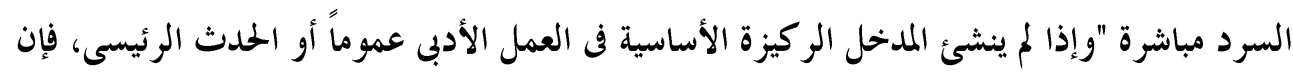

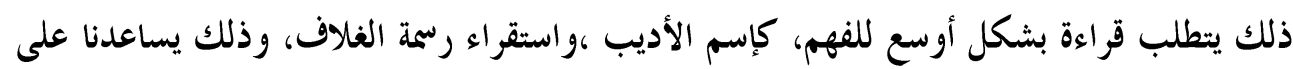

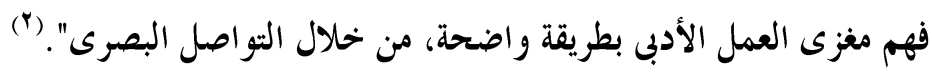

مما سبق يمكن القول إن عتبات النص هى مفاتيح العمل الروائى، وبوابتنا التى ندلف منها إلى الى

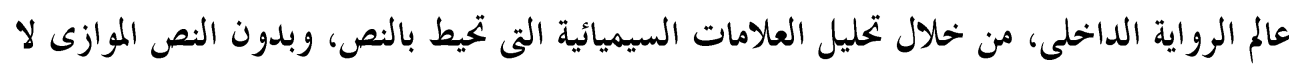

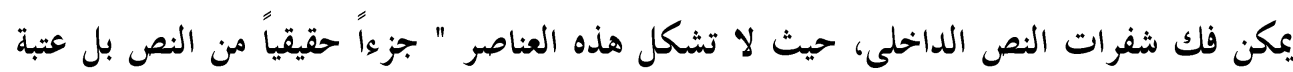

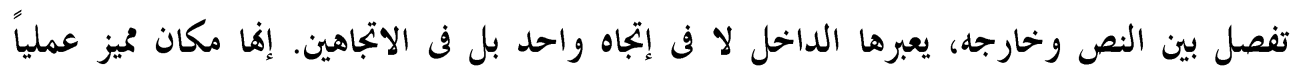

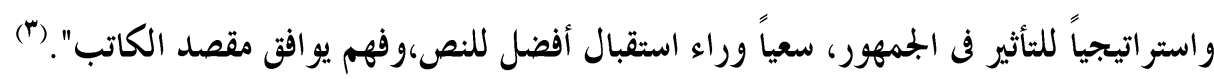
مما يؤكد على أهمية تلك العتبات فى الرواية هنا ،إشارة الأديب لها في أكثر من موضع دليل منه

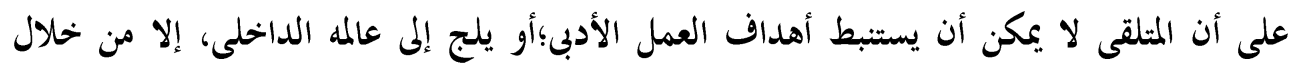
استقراء عتباته، سواء كان ذلك بعمد أم دون عمد ولكنه وقف على تلك العتبات بطريقة رمزية،

(1) يوسف الإدريس،عتبات النص، بحث ف التراث العربي والخطاب النقدى المعاصو، منشورات مقاربات،الطعة

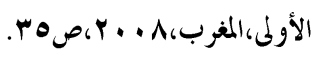

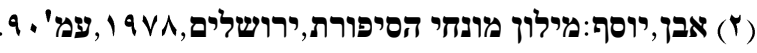

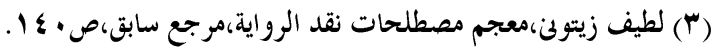


فنجده يقول على لسان البطلة :" ואבישגם פשארת במטבח בחברת אמה,עצסה לחזק

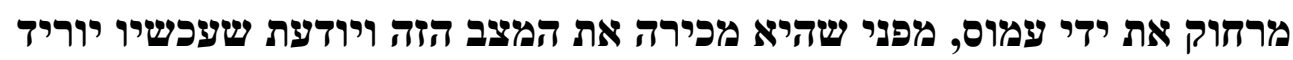

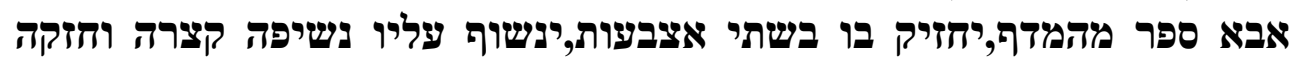

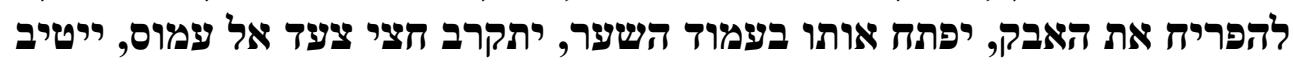

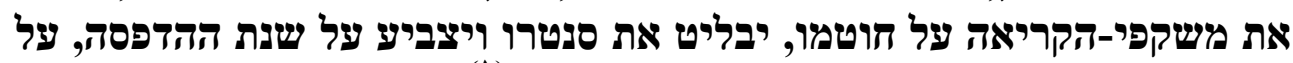

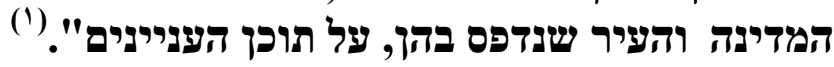

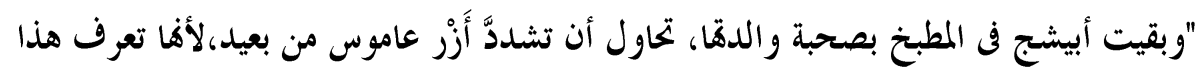

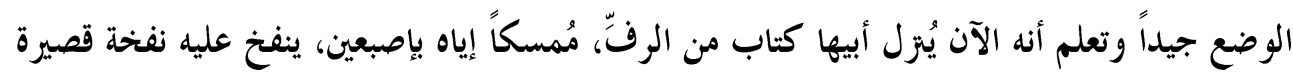

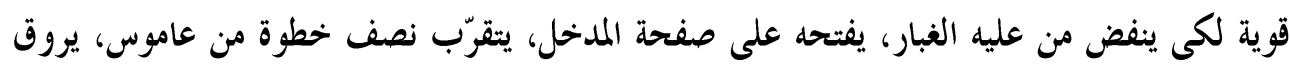

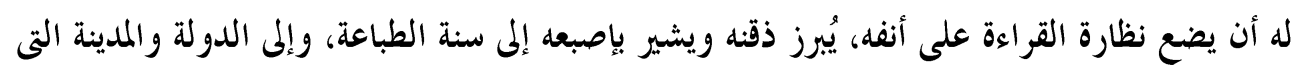
طُبعَت فيها، وإلى الفهرس".

يتضح من الفقرة السابقة مدى حرص والد البطلة، على معرفة عتبات النص قبل الدخول

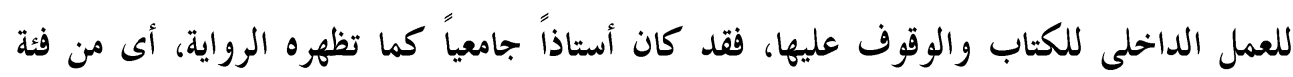
المثقفين، كما نجد في موضع آخر من الرواية: "אבא, אמרה לו. הוא נעצע לה

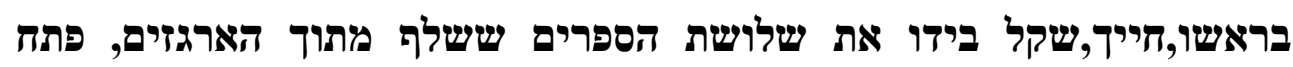

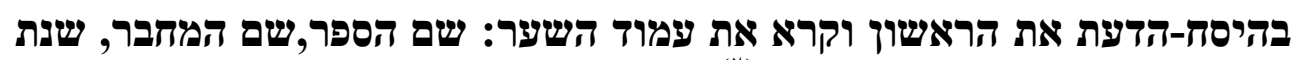

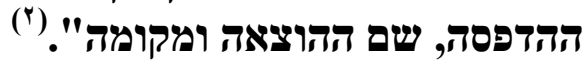
"قالت له، أبى. جاوبها برأسه، ابتسم، حاملاً فى يده ثلاثة كتب والتى سحبها من داخل

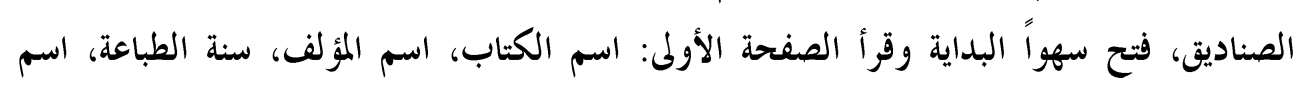

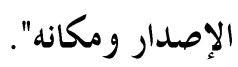

تؤكد الفقرة السابقة مع غيرها من الفقرات على أهمية عتبات النص سواء بالنسبة لأى نص

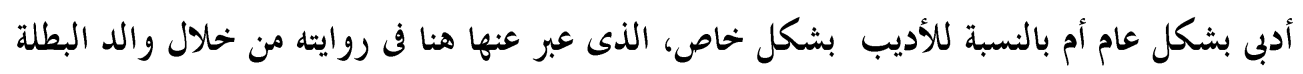

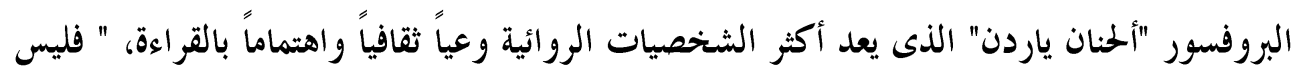

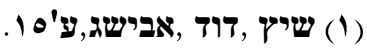

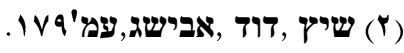


غريبا أن يهتم النقاد والباحثون السيميائيون بموضوع العتبات النصية، مادامت أبحاثهم تسعى إلى تحليل

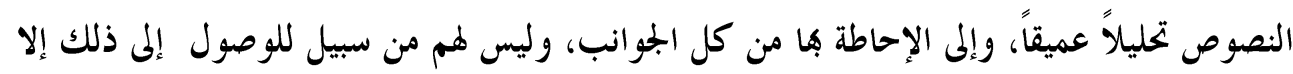

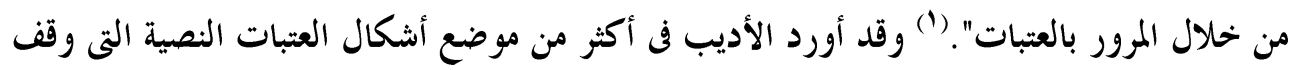

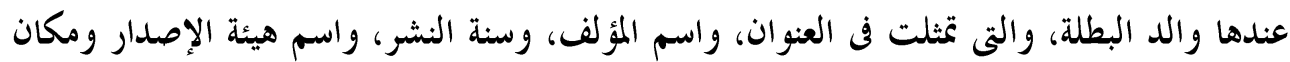

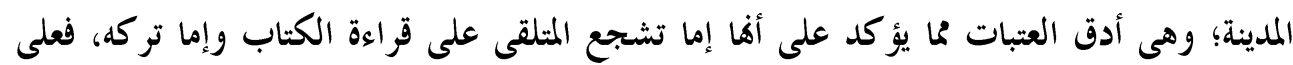

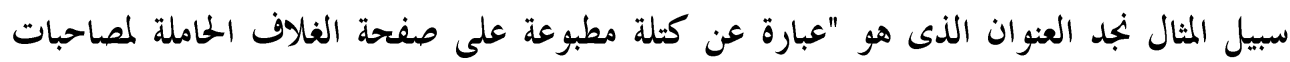

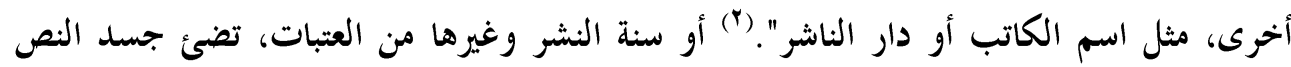
الداخلى، وتمكن القارئ من التعرف إلى فكر المؤلف واتجاهاته الثقافية، والسياسية، والتاريخية،

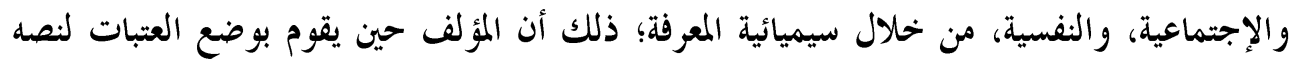

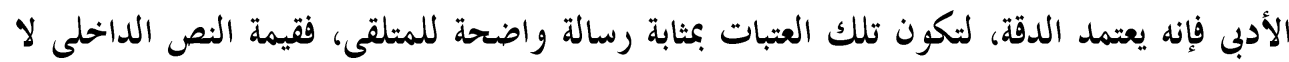

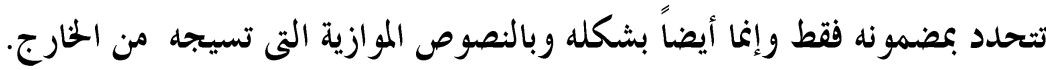

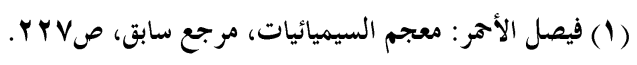

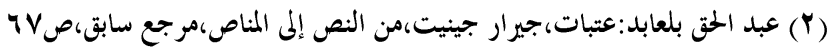


$\checkmark \wedge \Lambda$ 


\title{
التز اث الثعبي في المجموعة القصصبية "ديل و بازديل" ل بجلال آل أحمد
}

Folklore in Collection of stories" Did o Bazdid " for Jalal Al Ahmad

\author{
شيماء صادق علي صادق \\ مدرس مساعد بقسم اللغات الشرقية
}


79. 


\section{الملخص}

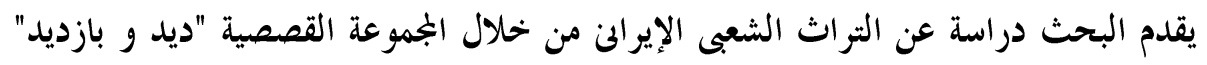

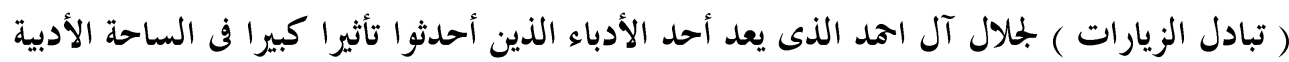

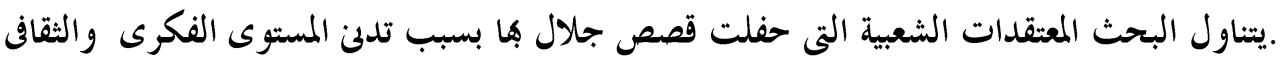
داخل الجتمع الإيرابن إبان الحرب العالمية الثانية ، وقد وظف جلال المال تلك المعتقدات بهدف السخرية

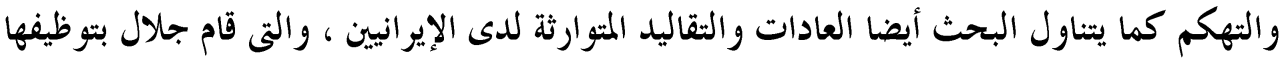
بهدف الحفاظ على الهوية الإيرانية ، ونقد العادات والتقاليد البالية التى تعوق حركة التقدئ، لتعدم داخل

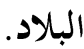

\section{Abstract:}

The research represents a study about Iranian folklore through a collection of stories "Did o Bazdid" (Exchange of visits) for Jalal Al Ahmad which is considered one of the writers whom influenced the literary stage greatly. This research deal with the popular beliefs which the stories of Jalal has been full of it because of the low intellectual and educational level inside the Iranian society during WWII, and Jalal has used these beliefs to mock it and be sarcastic about it, and this research also deals with the tradition passed by generation to another for Iranian people, which Jalal has used to maintain the Iranian identity, and he criticized the old tradition that might hinder the development inside the country. 


\section{أولاًا : تعريف التراث :

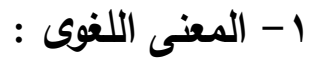

"التراث فى اللغة مشتق من مادة ورث ـ وتدل مادة " ورث" في معاجم اللغة العربية على المال

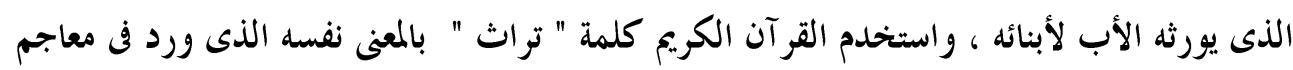

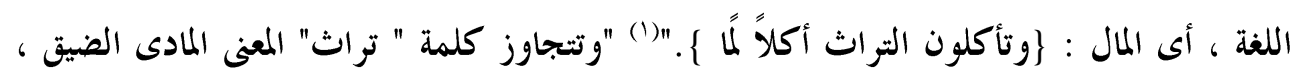

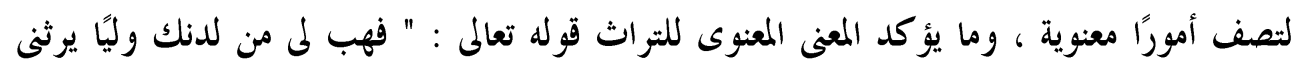

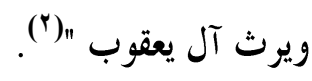

r - المعنى الاصطلاحى :

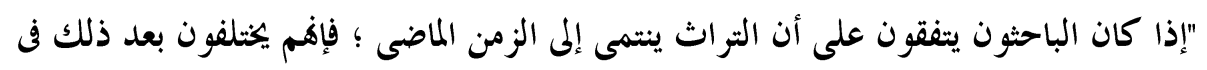

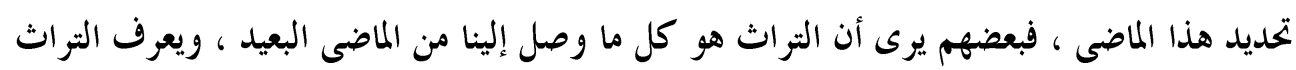

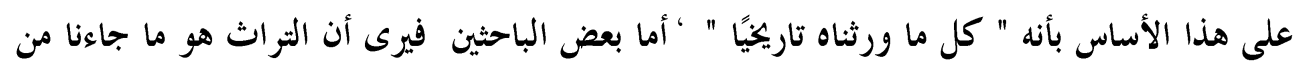

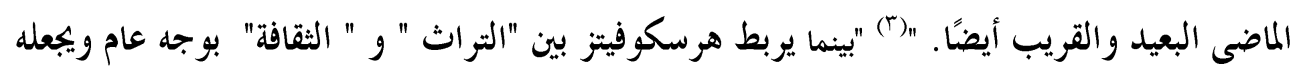

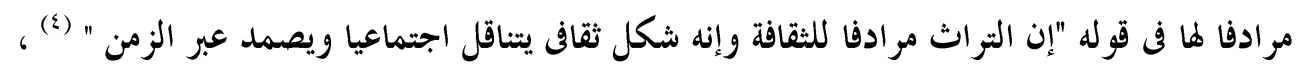

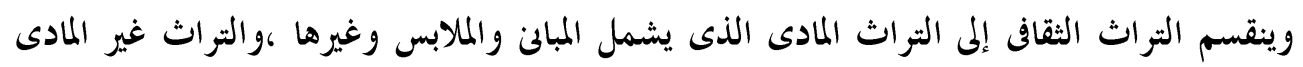

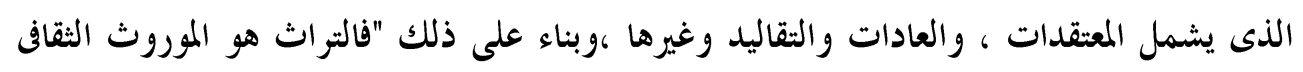
والاجتماعى والمادى ، المكتوب والشفوى، الرسمى والشعبى، اللغوى وغير اللغوى، الذى وصل ولمعل إلينا

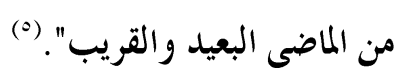

(1) محمد رياض وتار : توظيف التراث ف الرواية العربية المعاصرة ، الطبعة الأولى ، منشورات اتحاد الكتاب العرب ، دمشق ،

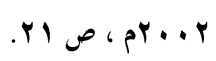

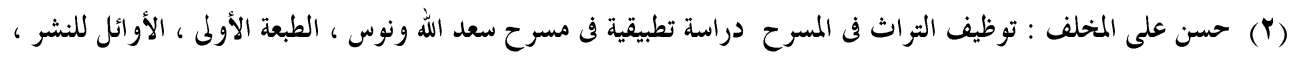

$$
\text { r. r... }
$$

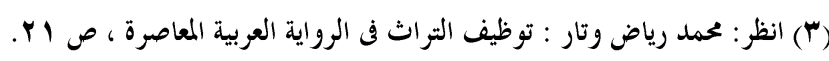

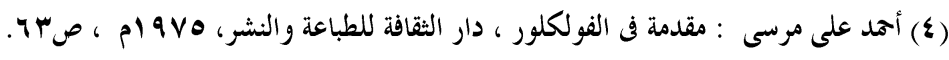

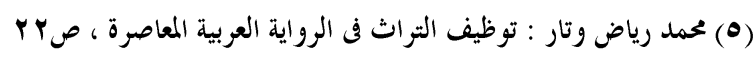




\section{ثانيًا: مفهوم التراث الثعبى :}

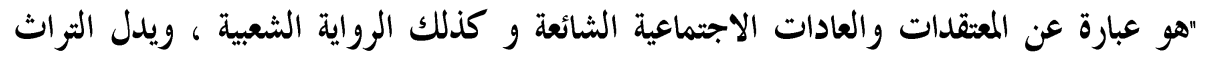

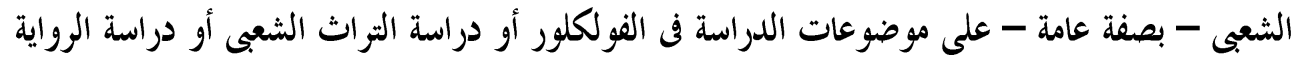

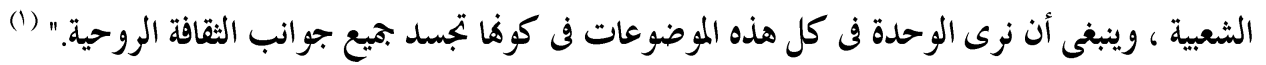
"اجتهد علماء الفولكلور الغربيون والعرب في تصنيف مواد التراث الشعبى، ومن تلك الجهود تقسيم Dorson

$$
\begin{aligned}
& \text { 1- الأدب الشعبى . } \\
& \text { r- الحياة الثعبية أو الثقافة المادية. } \\
& \text { ب- ب- العادات الاجتماعية والمعتقدات الشعبية . } \\
& \text { ع - فنون الأداء. }
\end{aligned}
$$

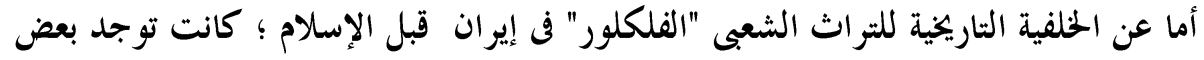

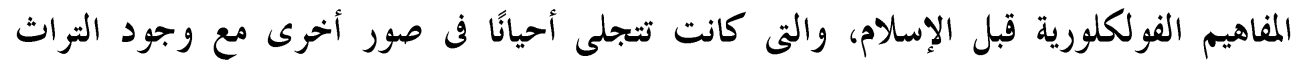

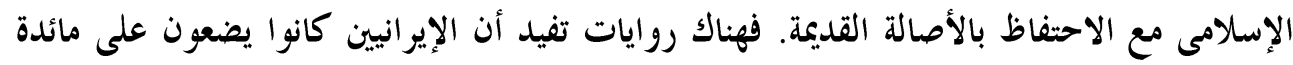

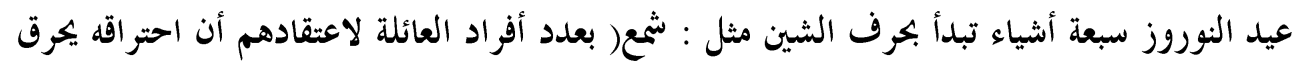

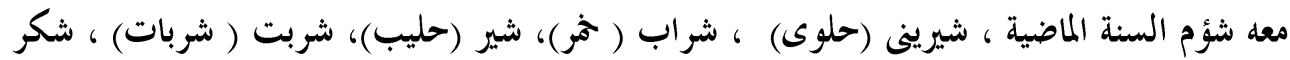

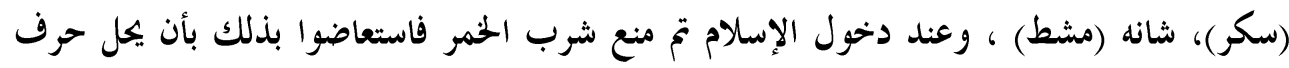

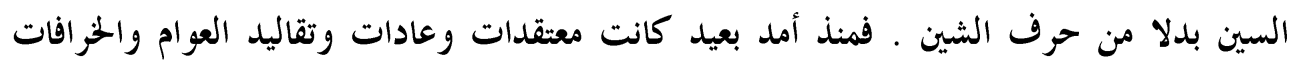

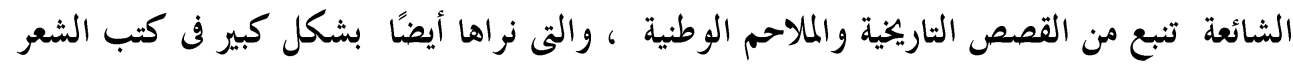

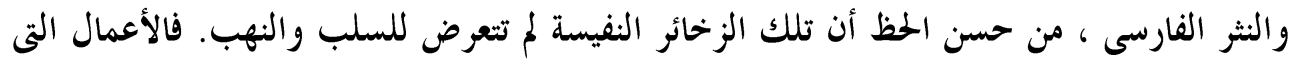

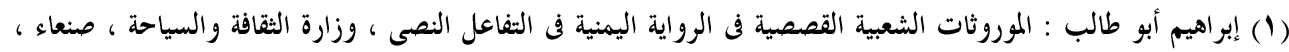

$$
\text { rl، r. r. }
$$

يعل : Richard Dorson (*)

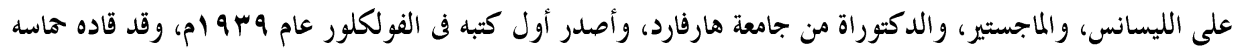

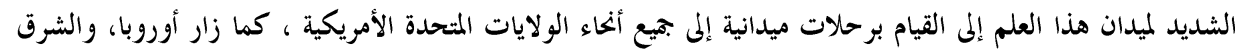

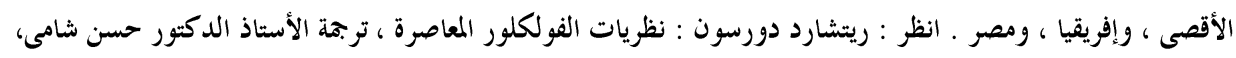

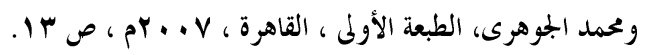




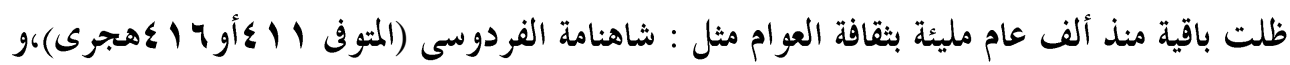

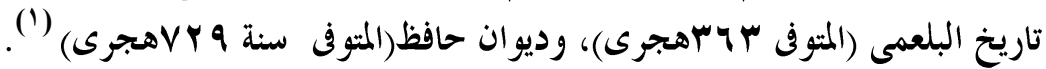
ثالثًا: موضوعات التراث الشعبى : 1 - المعتقدات الثعبية :

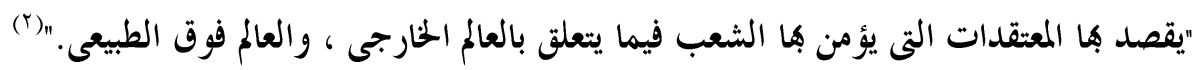

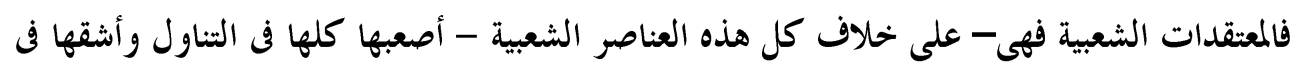

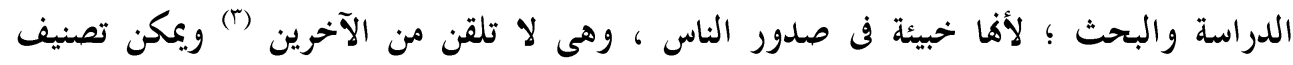

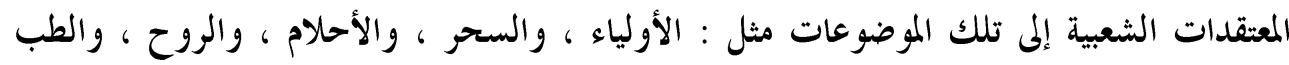
الشعبى ، والكائنات فوق الطبيعية.

r- العادات والتقاليد الثعبية:

"العادات والتقاليد ظاهرة أساسية من ظواهر الحياة الاجتماعية الإنسانية وهى حقيقة أصيلة من

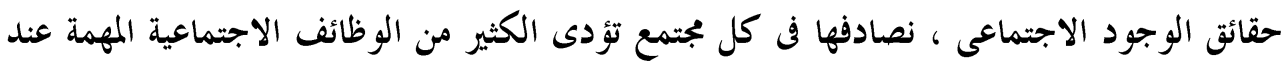

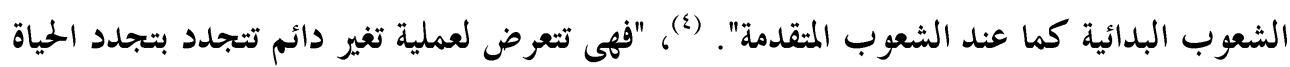

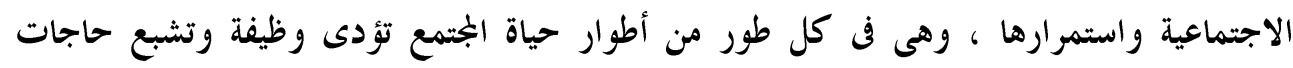

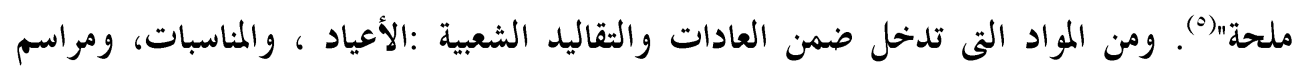

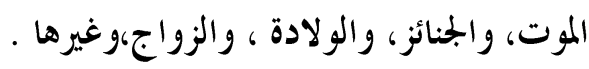

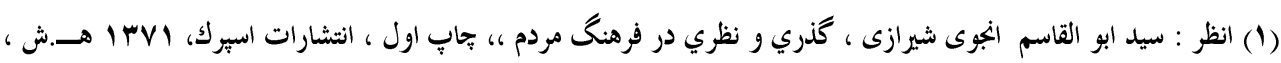

(r) حسن على المخلف : توظيف التراث في المسرح ، ص ror.

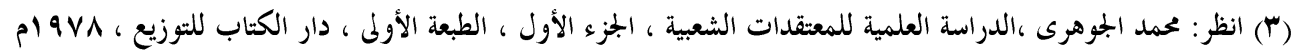

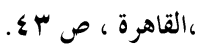

$$
\begin{aligned}
& \text { (ع) إبراهيم أبو طالب : الموروثات الشعبية القصصية في الرواية اليمنية في التفاعل النصى ،ص. • ع. }
\end{aligned}
$$

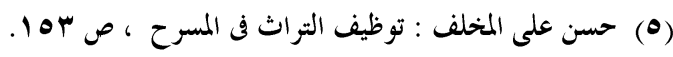

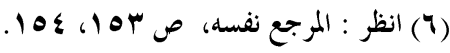


"تكمن أهمية الفنون الشعبية فل قدرها على كشف وفهم تراث بعض الجمان الجماعات المنعزلة

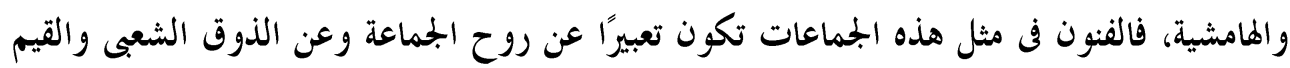
الجممالية الشعبية ، وتشتمل على الموضوعات الآتية: 1- الرقص والألعاب الشعبية. ب- الموسيقى الشعبية. ب- فنون التشكيل الشعبى."(1)

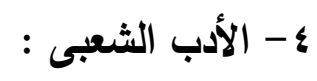

"يرى بعض الباحثين أن الأدب الشعبى لا يمكن أن يكون شعبيًا إلا إذا استقبلته الجماعة الشعبية

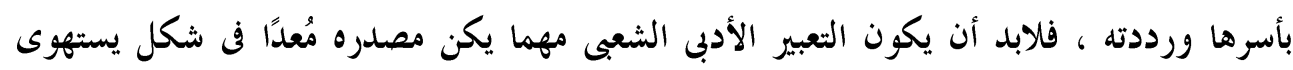

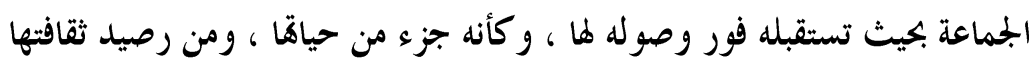

القديعة. " (\&) ويحفل الأدب الشعبى بأشكال عديدة تعد انعكاسًا لروح الشعوب والأمم مثل:

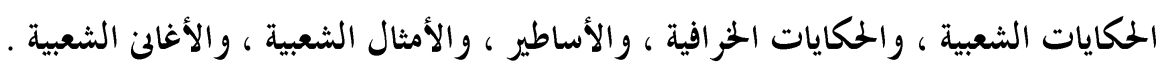

ثانيا : المعتقدات الثعبية فى " ديد و بازبيد":

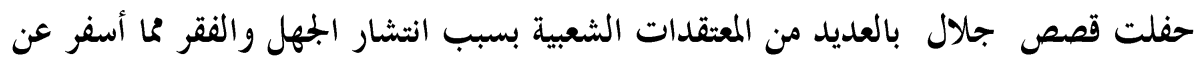

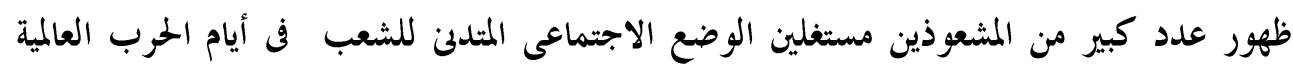
الثانية (1939-1945) ومن تلك المعتقدات السائدة في تلك الفترة:

1- الاستثفاء بماء المطر فى شهر نيسان (أبريل ) من المعتقدات الشعبية السائدة لدى كثير من الإيرانيين التبرك بعاء الدعاء. "وكانوا يقومون

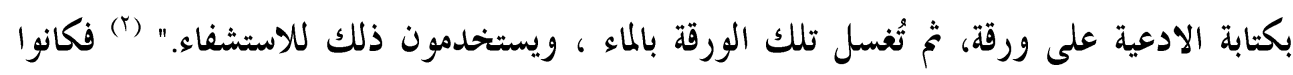

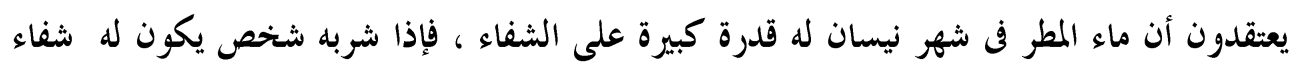

(1) إبراهيم أبو طالب : الموروثات الشعبية القصصية في الرواية اليمنية في الثفاعل النصى ، صع ع.

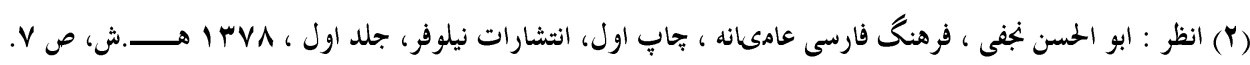


لكل داء. وقد عبر جلال في قصة " تبادل الزيارات فى العيد " عن هذا المعتقد السائد فى البتمع بمدف السخرية ، إذ يقول :

- لقد أعددت بيدى ماء الدعاء على طريقة المرحوم والدى ـ كتبت دعاءه، وغسلته بنفسى فى

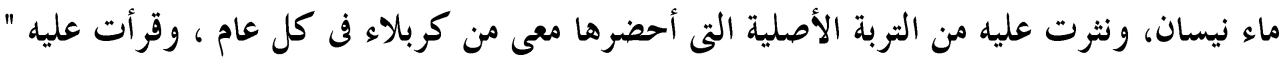

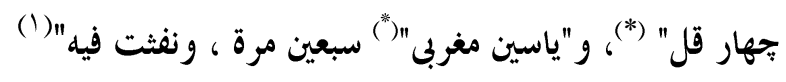

Y - الاستشفاء بتربة الضريح الحسينى :

" ويعرف لديهم بأن "ماء التربة هو الماء الذى أُخذ من شط الفرات ويتم خلطه بقليل من التراب

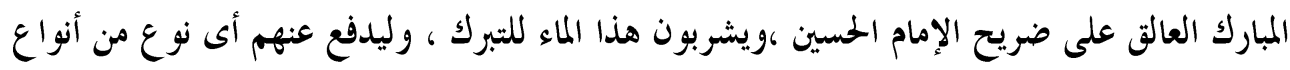

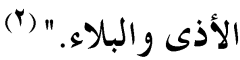

وقام جلال بتوظيف هذا المعتقد في قصة " الزيارة " همدف السخرية من تلك المعتقدات التى تسهم في تخلف الجتمع، فيقول : - أنا نفسى في الوقت الذى كنت فيه طفلاً ، كنت مريضًا جدًا ، لازلت أتذكر أننى شُفيت

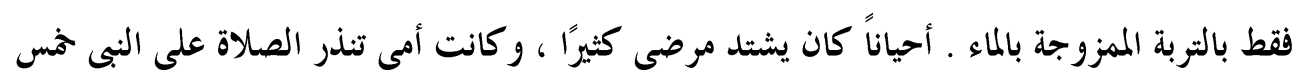
مرات بالسبحة.

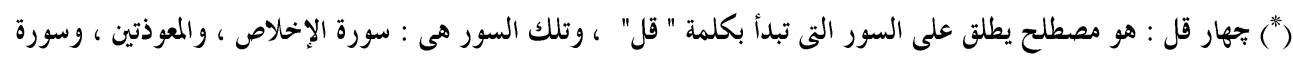

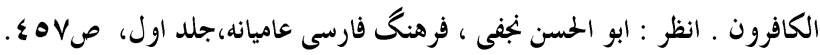

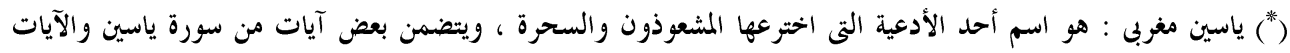

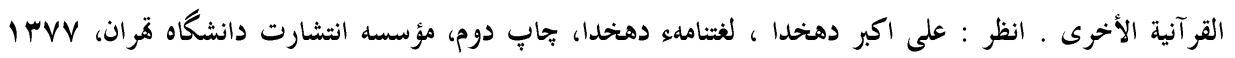

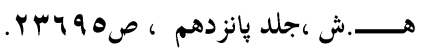

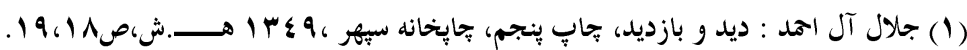

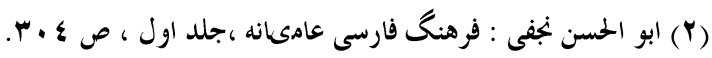

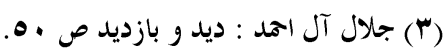

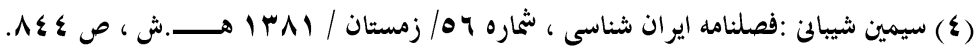
(•) جلال آل احد : ديد و بازديد، ص سب، ع س. 


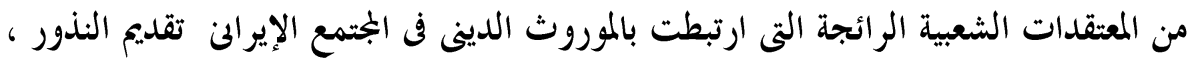

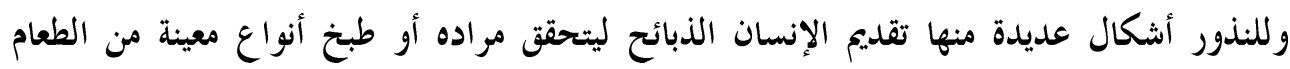

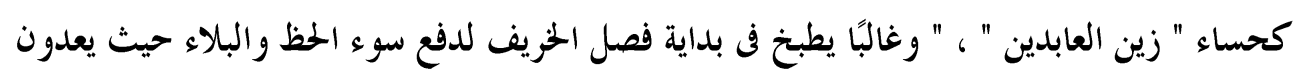

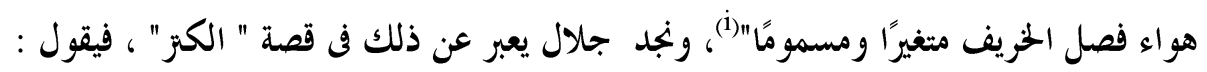
- وقامت بنذر ختسة عشر خروفًا من أجل "سيد ولى" الذى أكتشف شاهد قبره مؤخرًا ،

$$
\text { وكانت تطبخ " حساء زين العابدين" (ii)... }
$$

ع- استخدام الطست كشفاء للنساء العقيمات

من المعتقدات الخر افية في إيران استخدام الطست كثفاء للنساء العقيمات ، ويعرف هذا المعتقد

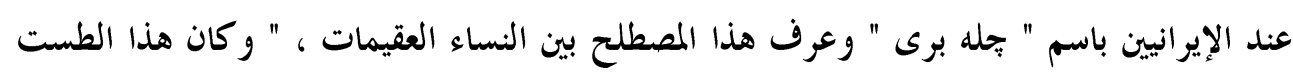

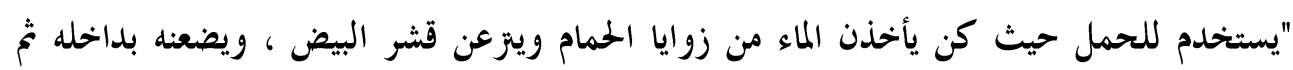

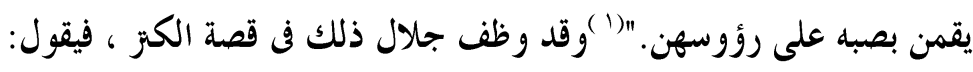
- كانت تذهب إلى كل كاتب أدعية تقع عيناها عليه ، وتشرب كل دواء تعطيه شيخة لها ،

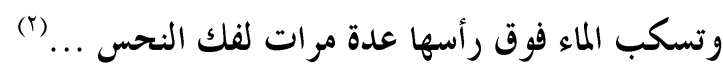
ه- خياطة الثوب المبروك: - م

"هو الثوب الذى تحمله المرأة إلى المسجد فى اليوم السابع والعشرين من شهر رمضان لجلب

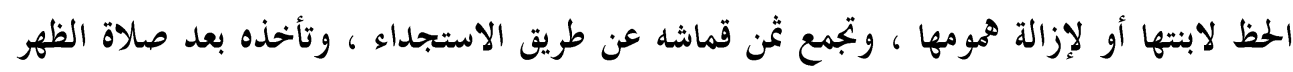

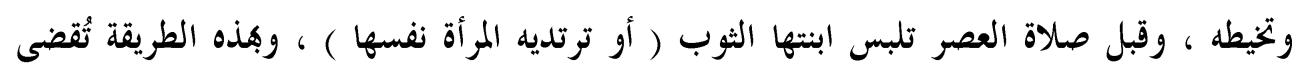

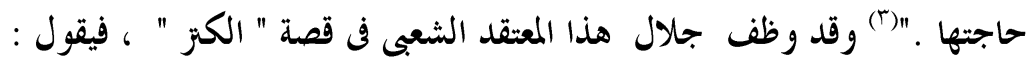

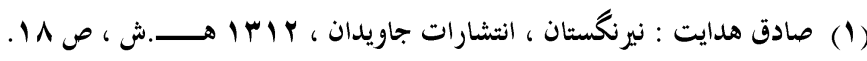

$$
\begin{aligned}
& \text { (ז) جلال آل اهد : ديد و بازديد، ص سٓ. }
\end{aligned}
$$

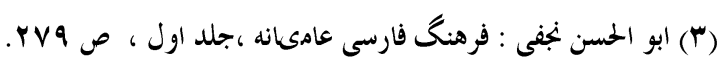


-... كانت تعد قطعة من القماش الأبيض التى كانت تتجدى ثمنه من هذا وذاك ، وتأتى إلى كالى

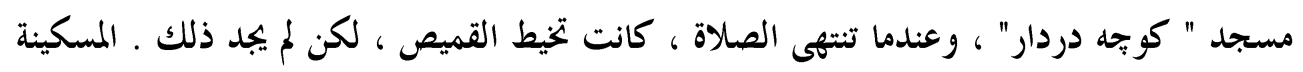

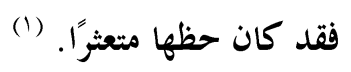

\section{צ- كتابة الأدعية والطلاسم والحروز:}

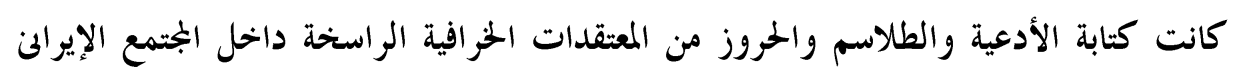

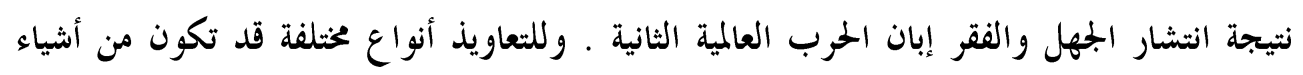

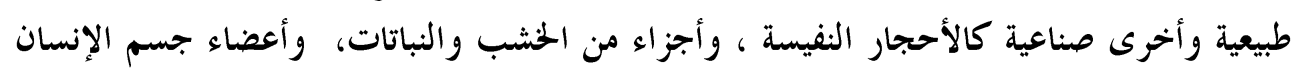

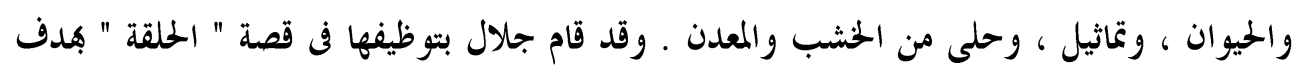

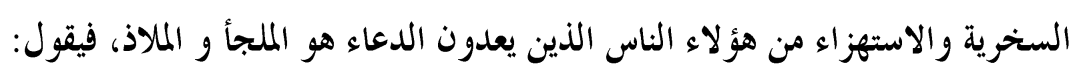

- كانوا يتباهون بوضع الدعاء على أبواب وجدران الغرف ، وبين الأطر الزجاجية الملونة

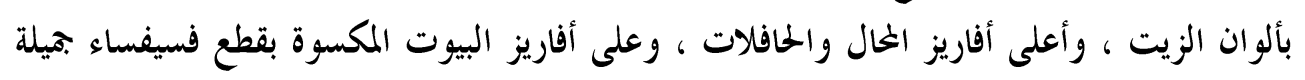

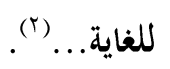

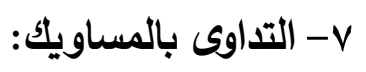

لا شك أن تلدن المستوى الثقافى فى الجتمع الإيرالن فى تلك الفترة بسبب انتشار فكر الدجل

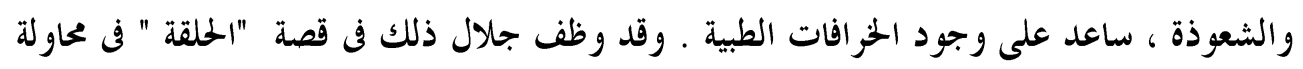

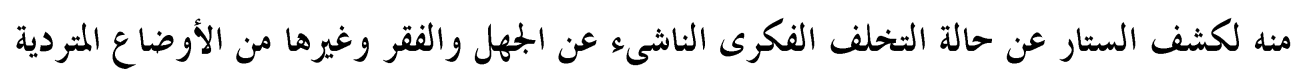

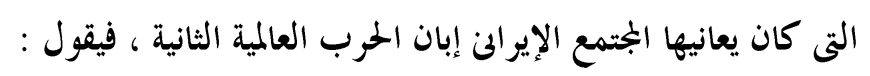

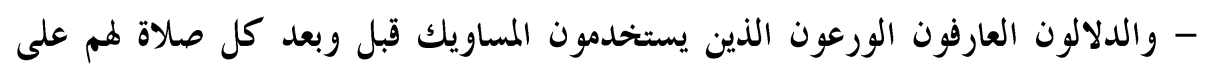

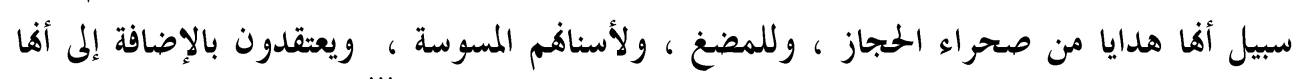

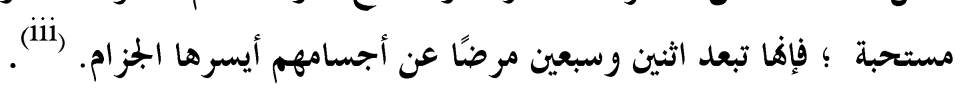

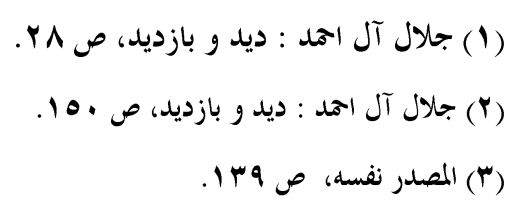




\section{ثانيا : العادات والتقاليد فى " ديد و بازديد"}

تعدد أسفار جلال ورحلاته ، واطلاعه عن كثب على الأوضاع المعيشية للمو اطنين ، ومشار كتهم

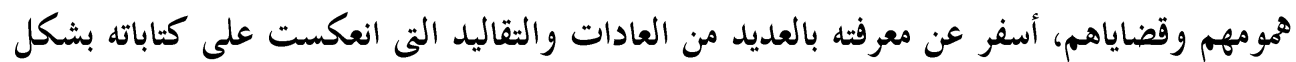
كيير، ومن العادات والتقاليد التى أوردها في " ديد وبازديد":

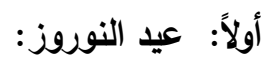

يعد عيد النوروز أحد الأعياد التقليدية التى يكتفل ها الإيرانيون بمناسبة حلول السنة الشمسية

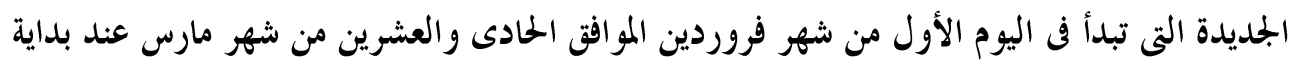

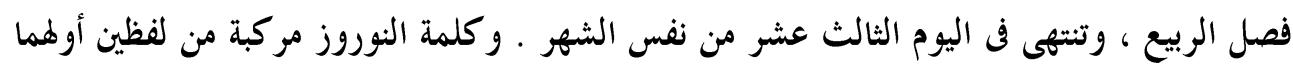
كلمة " نو " أى الجديد ، وثانيهما كلمة " روز" أى يوم ، فهى تأتى بمعنى (اليوم الجديد ) . ومع قدوم عيد النوروز تبدأ مظاهر الاحتفال التى أصبحت من التقاليد الراسخة لدى الإيرانيين

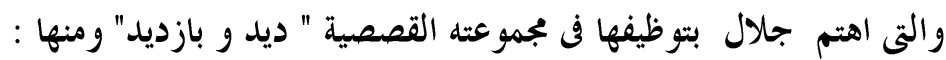

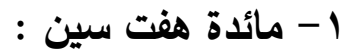

هى عبارة عن مائدة تتضمن أنواعًا من الأطعمة التى تبدأ بحرف السين على أن تضم سبعة أنواع

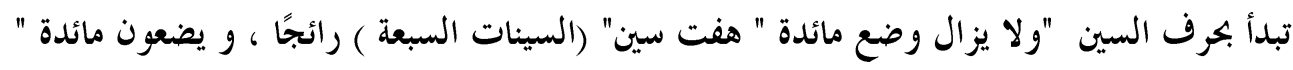

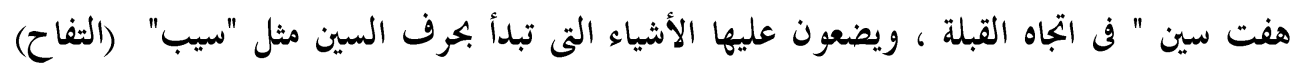

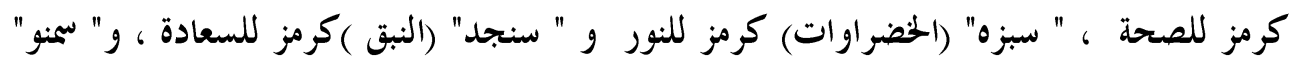

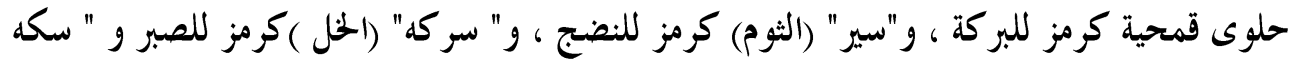

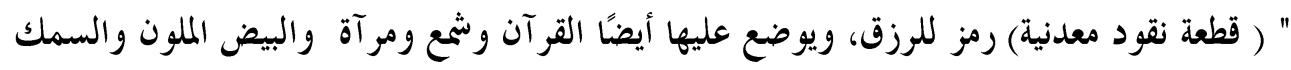

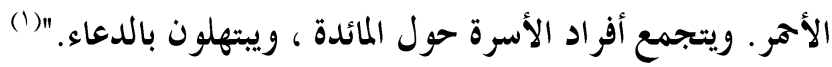

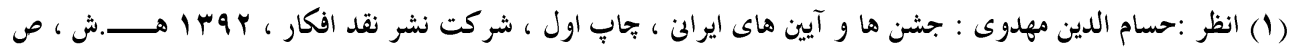

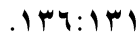


بعد بدء السنة الشمسية عادة يبدأ تبادل الزيارات بزيارة الصغار للكبار ، و كانوا يستقبلون

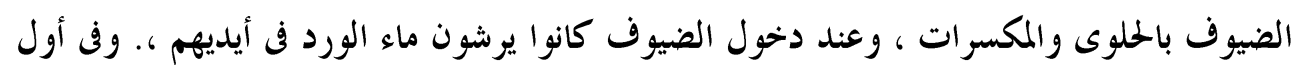

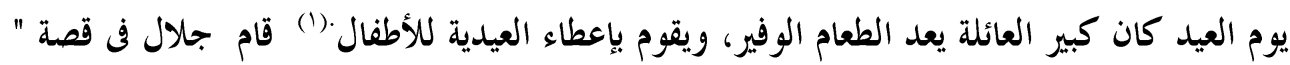
تبادل الزيارات في العيد" بتوظيف عادة تبادل الزيارات بين الأسر والمعارف ، فيقول : -كان حول الطاولةالمستديرة المليئة بالحلوى الغربية و والمكسرات الشهية ، أناس من جميع

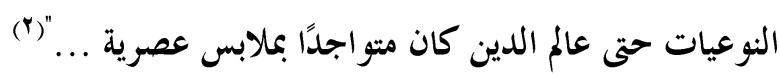
r - دعاء تحول السنة الثمسية:

من الطقوس الأخرى التى تمارس عند بلدء السنة الشمسية الجحديدة الدعاء وقت تحول الشمس إلى

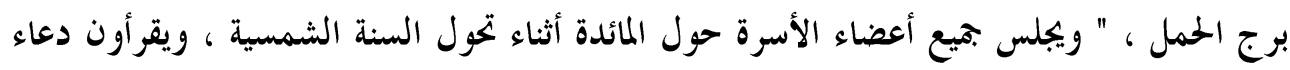

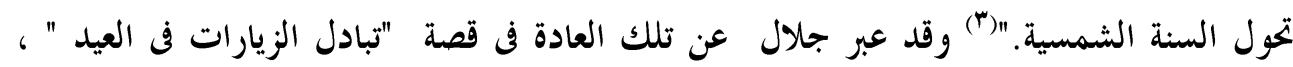
فيقول:

- أحدهم وصل من طريق السفر لتوه ، ولم يمهله حظه أن يوفق ، ويدعو دعاء تحول الشمس

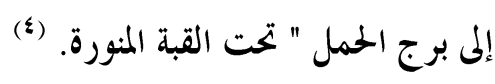

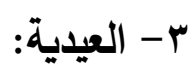

"تعد العيدية أو الهدية في عيد النوروز من التقاليد القديمة ؛ وهى العادة التى لاتزال قائمة بين

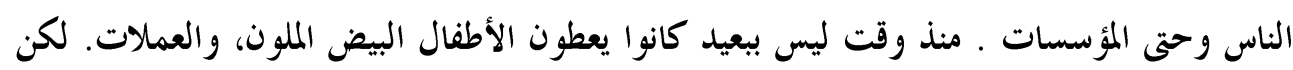

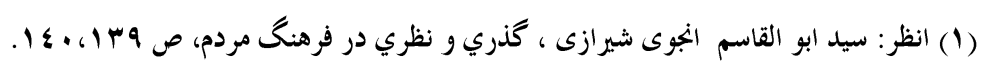

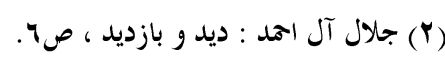

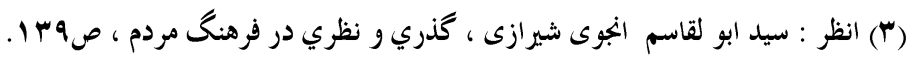

$$
\begin{aligned}
& \text { (ع) جلال آل اتمد : ديدو بازديد ، ص } 19 .
\end{aligned}
$$


العيدية اليوم تكون غالبًا بصورة نقدية ( العملات الورقية الجديدة)". (") وقد وظف جلال العيدية "

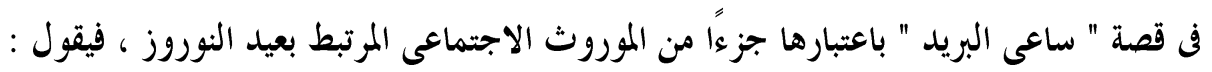
- كان قد أحضر لم بعض رسائل وقالم العيد،وطالب الشخص الذى كان أمام الباب بالعيدية

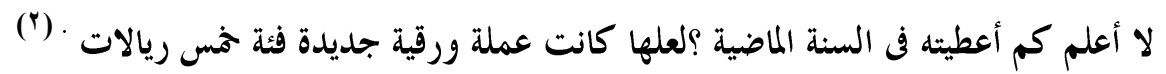

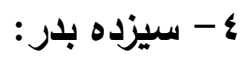

هو اليوم الثالث عشر من شهر " فروردين" (أبريل) ، والإيرانيون يعدون هذا اليوم نحسًا ، ولذا

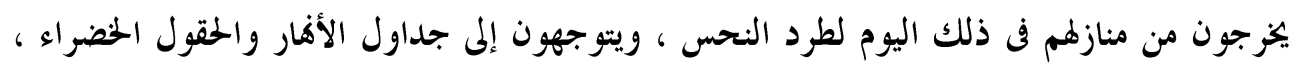
ويلهون ويفرحون (r) ، ويلقون البراعم الخضر اء التى كانت موضوعة على مائدة " هفت سين " في الماء

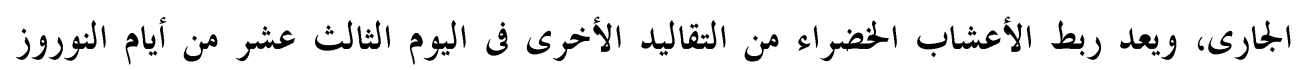

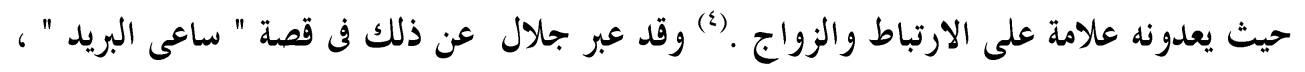
فيقول : - لم يأت بعد اليوم الثالث عشر من أيام العيد ، والناس لم يلقوا نباتات الحبوب المتنوعة من

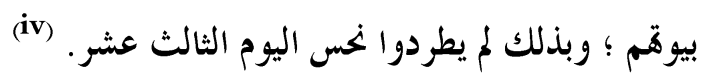
ثانيًا: طقوس زيارة الأولياء والعتبات المقدسة : تعد زيارة الأولياء والعتبات المقدسة من العادات الراسخة لدى الإيرانيين ، وعندما يستعد

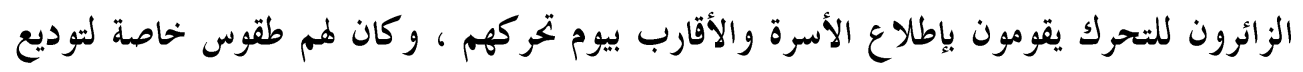

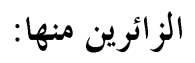

(1) حسام الدين مهدوى : جشن ها و آين هاى ايرامن ، صل 11 1.

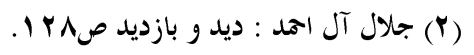

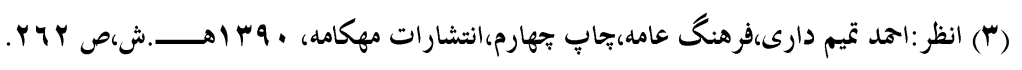

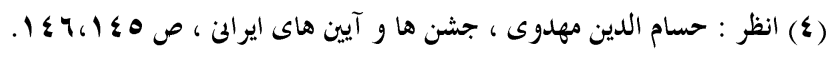
(0) جلال آل احد : ديد و بازديد ص آس ا. 
1 - إنشاد المراثى والمديح:

كان إنشاد المراثى والمديح من الطقوس اللازمة لمن يرغب فى السفر للزيارة ؛ لأن المنشد يحرك

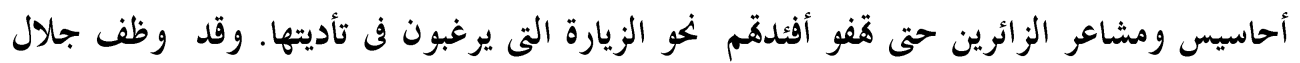
ذلك في قصة " الكنز "، فنجده يقول: - في إحدى السنوات عزم مشهدى حسن على السفر للزيارة ، والذهاب إلى كربلاء مع بتول

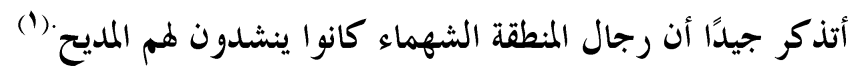

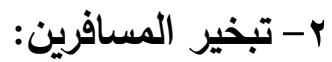
ومن العادات الشعبية الموروثة تبخير المسافرين بالحرمل والكندر من قبل أهالى المنطقة ، وقد

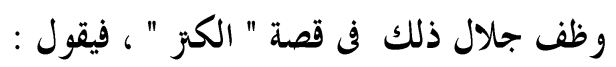
- و كثيرًا ما كان أهل المنطقة يبخروفم بالحرمل والكندر . تعلمون يا أحبائى ! ذهبا من هناك (ا) (יلى مكة. r- المرور من تحت القرآن وإلماء والطحين: صباحًا كان يبدأ السفر بتحرك المنشد،والزائرون يمرون من تحت القرآن ، والماء،والطحين، ويودعوفم الناس بتبخيرهم بالحرمل. وقد وظف جلال ذلك فى قصة " الزيارة " ، فيقول : -مررت ثلاث مرات من تحت القر آن والماء والطحين ، وفى المرة الثالثة قبّلت القر آن ، ووضعته

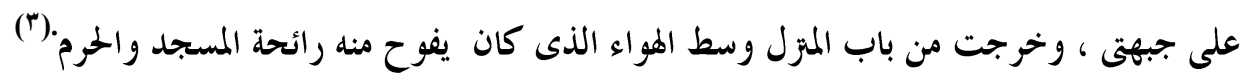
ع - التماس الدعاء:

كان التماس الدعاء من الأشياء التى يحرص عليها المودعون في طلبها من الزائرين ، فالناس

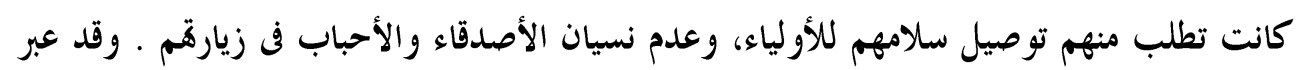
جلال عن ذلك فى قصة " الزيارة" ، فيقول :

$$
\begin{aligned}
& \text { (1) جلال آل احد : ديد و بازديد ،صץ. } \\
& \text { (Y) المصدر نفسه، صYr. }
\end{aligned}
$$

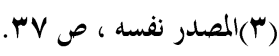


- كل من يصل إلى رأس الزقاق من قريب وغريب ، من أهل الحى أو من غيره ، كان يفهم أنى

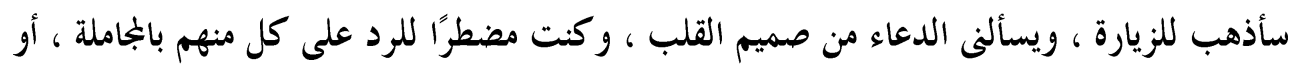

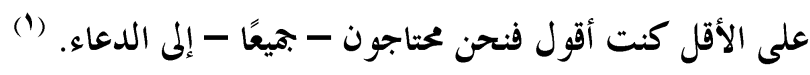
ه- الأذان وقراءة الآيات والأدعية فى الأذن اليمنى : ومن العادات الموروثة لدى الإيرانيين عند توديع المسافرين لزيارة العتبات المقدسة ، قيام أهل المنطقة

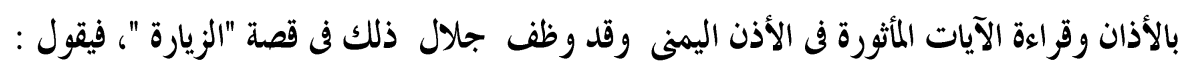
بعض الأشخاص من كانت تربطنى هم علاقة وثيقة لا يمكنهم أن يتركونن وشأن دون أن يؤذنوا في

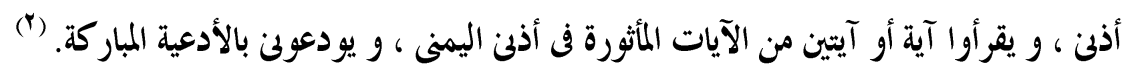

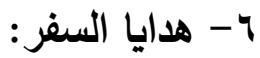
"هدايا السفر هى الهدايا أو النقود التى يمنحها المسافر للمودعين أو العكس" "(م)وقد عبر جلال

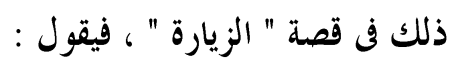

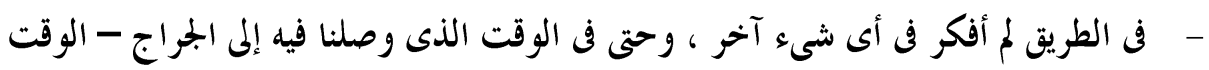

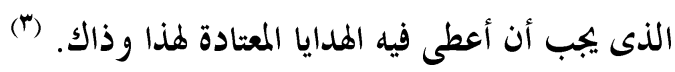

ثالثا : طقوس ما بعد الموت : ا

بعد وفاة الميت ، يحضرون التابوت إلى غرفة الميت ـ ويقومون بفرش اللباد في أرضية التابوت ،

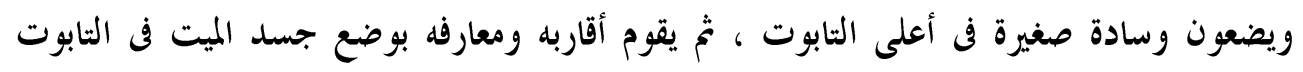

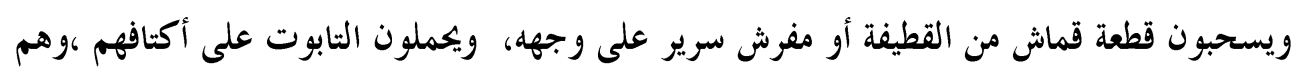

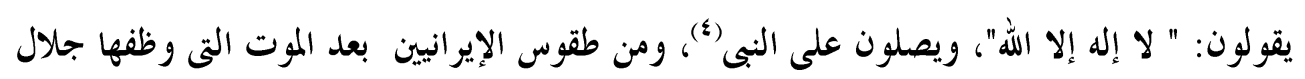
ما يلى :

$$
\begin{aligned}
& \text { (1) جلال آل اهد : ديد و بازديدص صV. }
\end{aligned}
$$

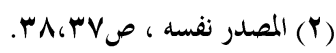

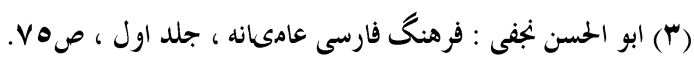

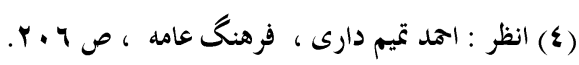




\section{1- شهادة أربعين مؤمنًا للميت بالخير:}

وظف جلال ذلك في قصة "التابوت" من خلال توقيعهم على قطعة القماش الموضوعة على

$$
\text { وجه الميت أوصدره، فيقول: }
$$

- هو على عكس ذلك السيد الذى وقع له أربعون مؤمنًا وسط كفنه الثمين المعطر المكتوب

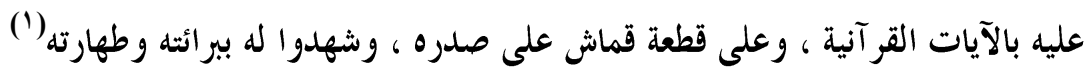
r- استحباب التابوت بدلاً من سيارات نقل الموتى: ومرة أخرى يوظف جلال فى قصة " التابوت" فكرة وضع الموتى فى التابوت بدلاً من سيارات نقل الموتى بهدف إبراز الصراع بين التقليد والحداثة ، فيقول : - لكن ما الفائدة ! عاد الزمن ـ الآن الجميع أحرار ، ولن يوضى الناس مرة أخرى أن يودعوا

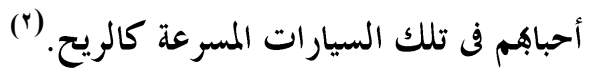
r- الأكرى الأسبوعية والأبعينية والسنوية :

مر اسم الوفاة عبارة عن مجلس ختم القر آن ترمًا على الميت ، و ليلة أسبوع الميت ، وذكرى

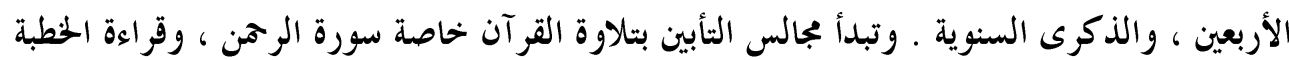

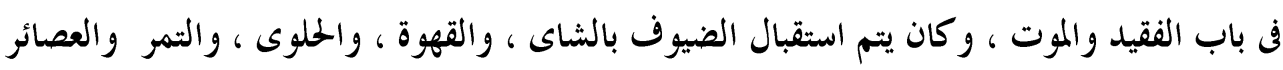

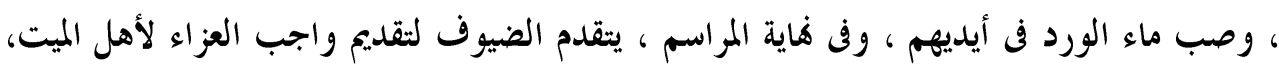

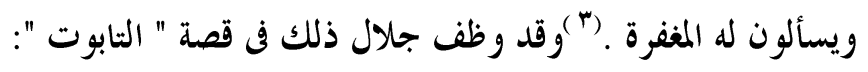
- ولن تنبعث رائحة الحلوى ودخان الموقد من أى بيت لا في ليلة أسبوع الميت ولا في ذكراه

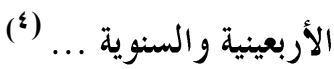

$$
\begin{aligned}
& \text { (1) جلال آل احد : ديد و بازديد ،هـ. }
\end{aligned}
$$

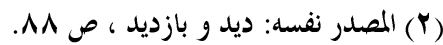

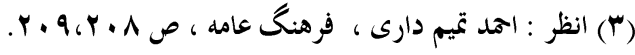

$$
\begin{aligned}
& \text { (ع) جلال آل احد : ديد و بازديد ، صعی، هم. }
\end{aligned}
$$




\section{رابعا : هايا المناسبات (المولود الجديد - الزفاف) :}

" يكتفل الإيرانيون بالمولود الجديد في الليلة السادسة من مولده ، ويجلس أقارب المرأة النفساء

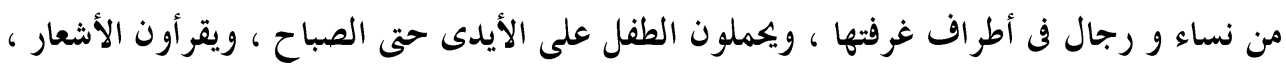

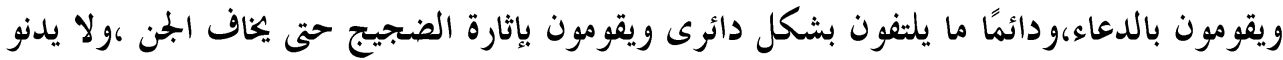

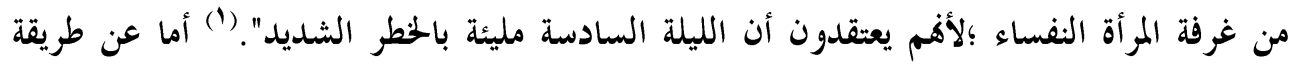

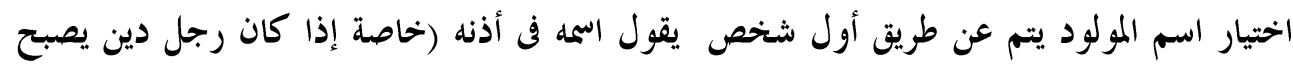

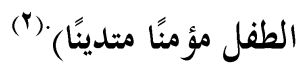

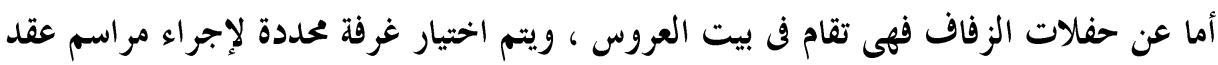

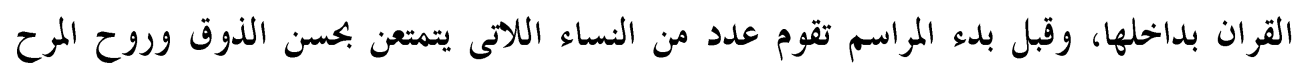

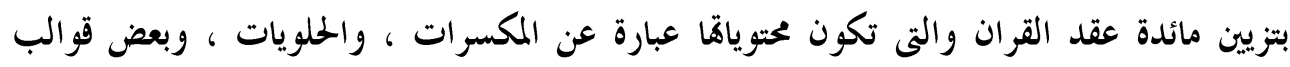

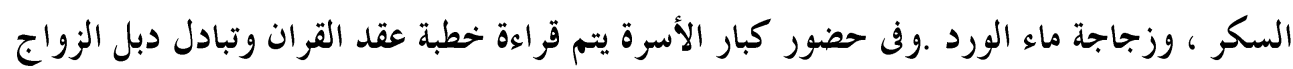

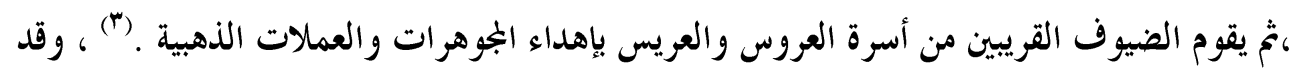
وظف جلال ذلك في قصة الكز، فيقول:

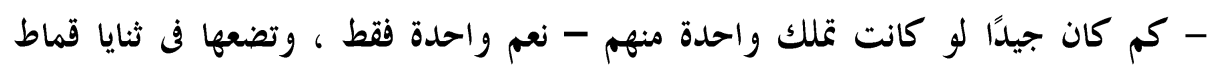

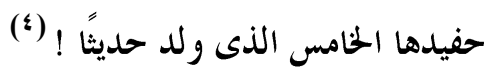

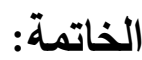

بعد دراسة الجموعة القصصية " ديد و بازديد" للأديب " جلال آل اهد" على يمكن استخلاص

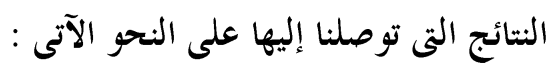

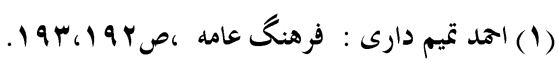

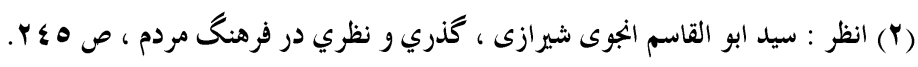

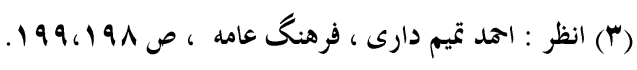

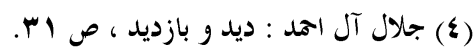


- شكل التراث الشعبى نصيبا كبيرا في الجموعة القصصية ،وألم بالكثير من من عادات وتقاليد

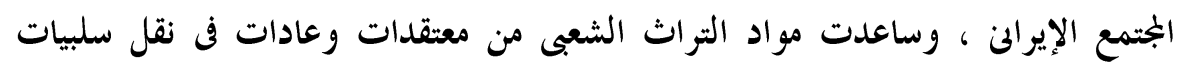

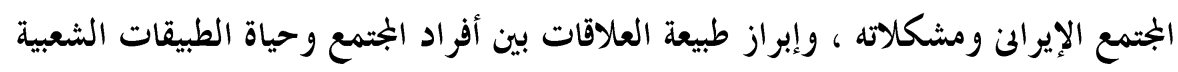

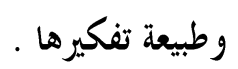

- وظف جلال آل اهد تلك المعتقدات الشعبية التى ظلت عالقة في الأذهان هـدف السخرية

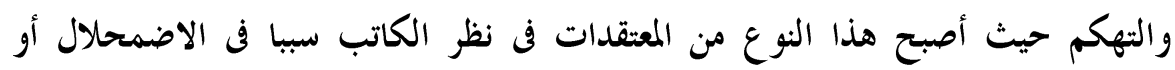
الانحدار الفكرى فى الجتمع خاصة المعتقدات الشعبية التى تمس الدين.

- حفلت الجموعة القصصية بالعديد من العادات والتقاليد التى تشكل نسيج البحتمع الإيرانى ،

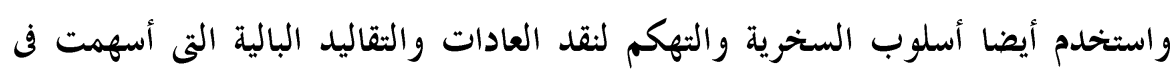

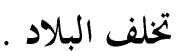

\section{قائمة المصادر والمراجع :}

\section{أولا المراجع العربية وإلمترجمة:}

- إبراهيم أبو طالب (د): الموروثات الشعبية القصصية فى الرواية اليمنية في التفاعل النصسى ، وزارة

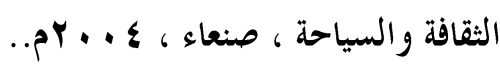

- أهد على مرسى (د) : مقدمة في الفولكلور ، دار الثقافة للطباعة والنشر، هV ام.

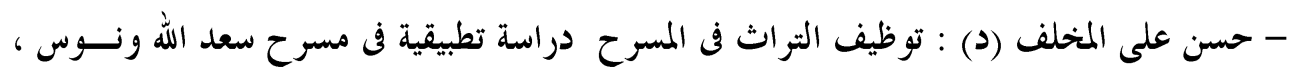

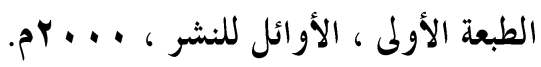

- ريتشارد دورسون : نظريات الفولكلور المعاصرة ، تربمة الأستاذ الدكتور حسن شامى ، ومحمــــ

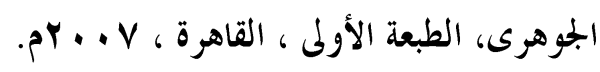

- محمد الجوهرى ،الدراسة العلمية للمعتقدات الشعبية ، الجزء الأول ، الطعة الأولى ، دار الكتاب

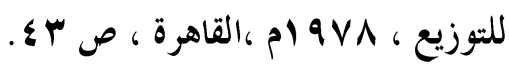

- محمد رياض وتار : توظيف التراث فل الرواية العربية المعاصرة ، الطبعة الأولى ، منشورات اتحســاد

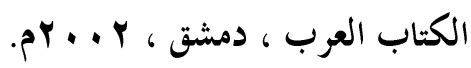




\section{ثانيا : المصادر والمراجع الفارسية :}

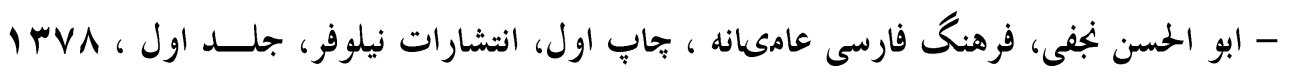
.

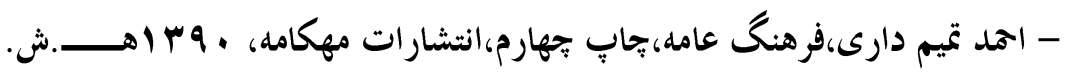

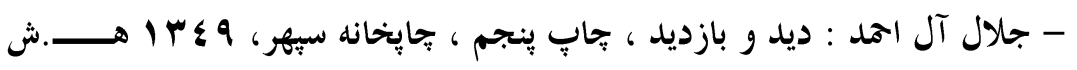

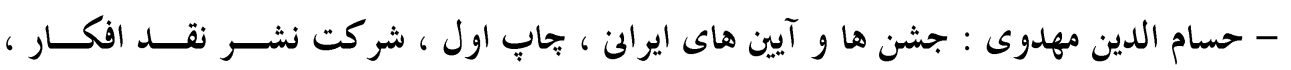

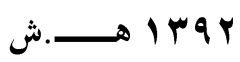

- سيد ابو القاسم انجوى شيرازى ، تذري و نظري در فرهنگ مردم ، جابِاول ، انتشـارات

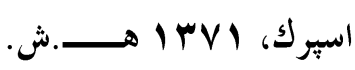

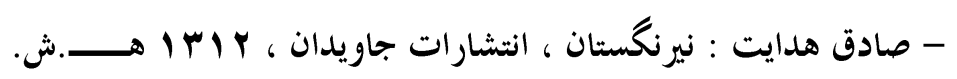

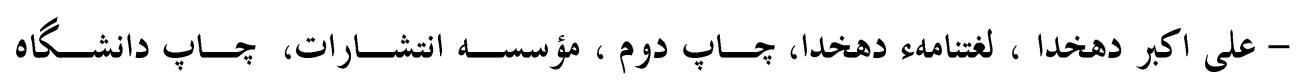

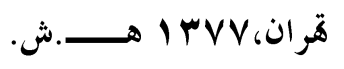

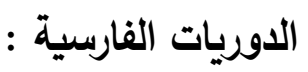

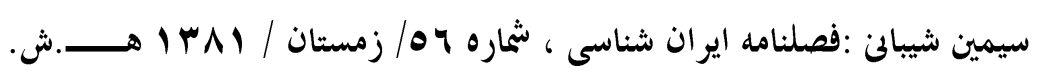


$V \cdot \Lambda$ 
التمييزبين اليهودي وغير اليهودي في العهد القديم

\author{
جماد محمود صلاح \\ قسم اللغات الشرقية - شعبة اللغة العبر ية
}

$v \cdot q$ 
vi.

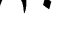


ترجع أهمية الديانة اليهودية من حيث إذها تعد من أقدم الديانات التوحيدية ، كما أن دورًا في

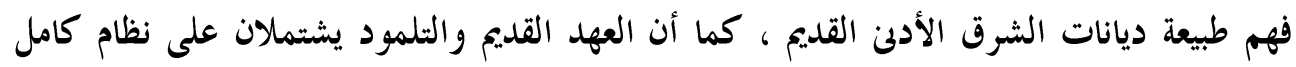

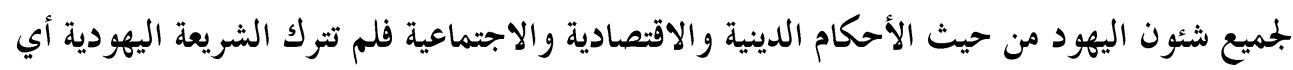

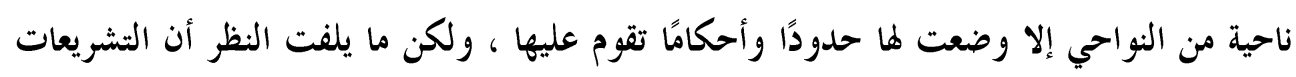

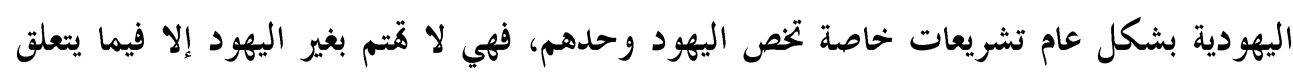

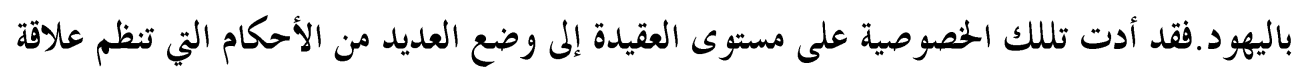

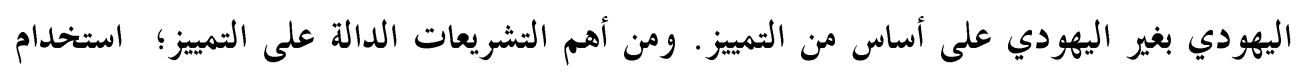

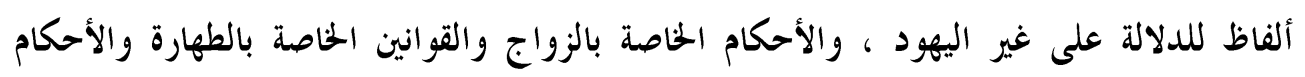

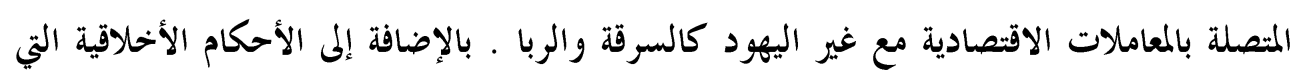

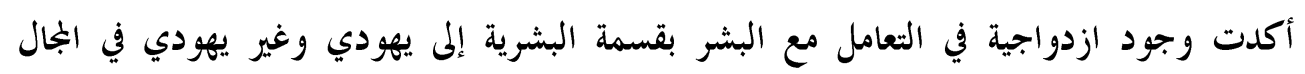
الأخلاقي وما يتبعه من سلوك عملي. فمن الممكن تقسيم التمييز في العهد القديم إلى :

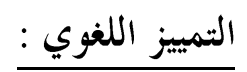

حيث إن العهد القديم يستخدم ألفاظا خاصة للدلالة على غير اليهود. التمييز في المعاملات الاقتصادية: كاستخدام الربا في المعاملات التجارية مع الأغيار، والسماح بسرقة غير الئهية اليهود. مثل تحريم الزواج من أجنبيات ، وسلب حق الابن البكر في حالة إن كون أمه غير يهودية،

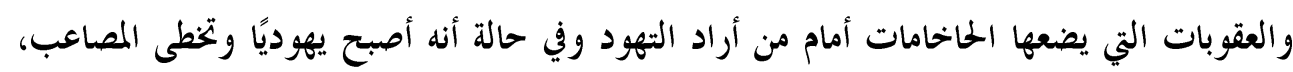
وغيرها من التعاملات الاجتماعية. أولاً: التمييز اللغوي في العهد القديم: 1- لفظ "גוי": إن العنصرية ضد غير اليهود في العهد القديم تبدأ باستخدام ألفاظ كان لها معنى عام ثم انحط

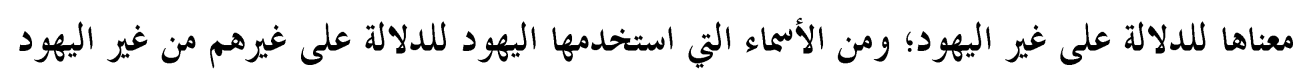


" عبدة النجوم والكو اكب ، المهرطقون ، الأجانب " الأغراب" ، سكان عالم الحياة الفانية أو البلهاء أو

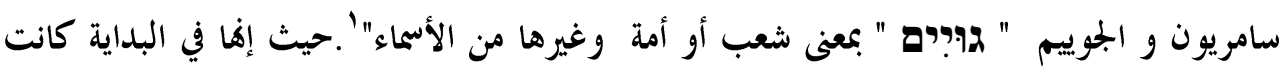

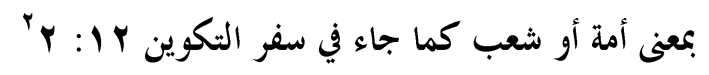

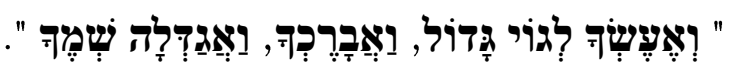

" أفعلك أمة عظيمة، وأبار كلك ، وأعظم أسمك".

ثم تمول معنى لفظ "هاי " للدلالة على الشعوب الوثنية أي غير اليهود كما جاء في سفر الملوك

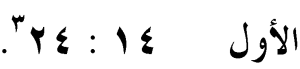

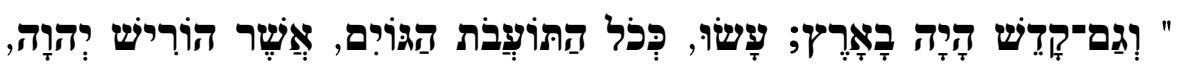

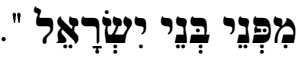

" و وكان أيضًا مأبونون في الأرض ، فعلوا حسب كل أرجاس الأمم الذين طردهم الرب من

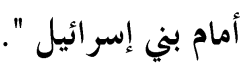

وأيضًا استخدم اللفظ ذاته للدلالة على غير اليهودي في سفر اللاويين ، عندما تمرد اليهود على ألى

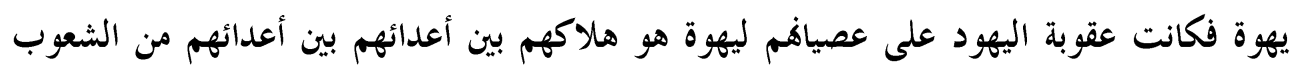
الأخرى؛

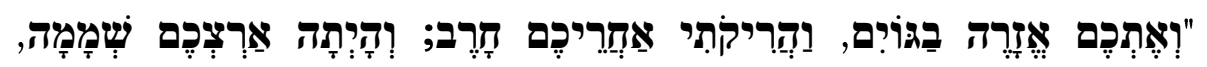

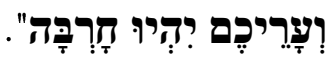

" و وأذريكم بين الأمم ، وأجرد وراءكم السيف فتصير أرضكم موحشة ، ومدنكم تصير خربة".

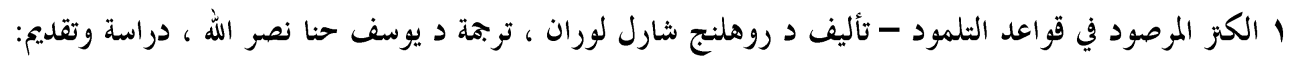

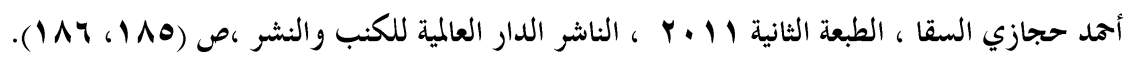

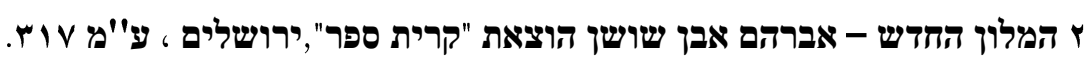
3 The old Testament- William Hebrew and English Lexicon of Gesenius p (156) .

ع سفر اللاوين بr: بr. 


\section{وجاء لفظ " هاب " في السفر ذاته ليدل على الأعداء والخصوم'.}

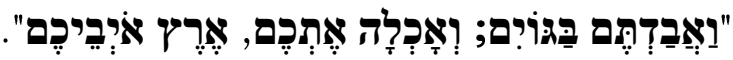 \\ " فتهلكون بين الشعوب ، وتأكلكم أرض أعدائكم".}

فمن هنا نلاحظ أن مصطلح جوي " هواי " هو مصطلح عبري يكثر استخدامه في الفكر الديني

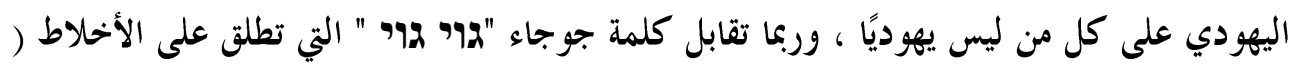

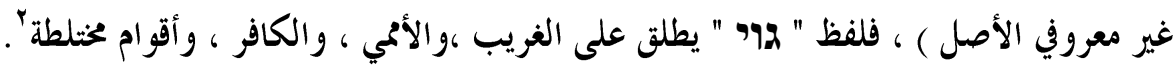
كما أفم يسمون كل ديانة غير يهودية باسم "جوياه" "Goiah"، وفي بعض الأحيان بل ومن النادر جلًا أن يطلق اسم جوي "هوأن" على الإسرائيلين ، وكثيرًا ما تسمى الكتب اليهودية التي تبحث في الوثنية بذلك الاسم "جوي" ، لذلك فإِن معظم طبقات التلمود الحمديثة تستخدم كلمة الإني

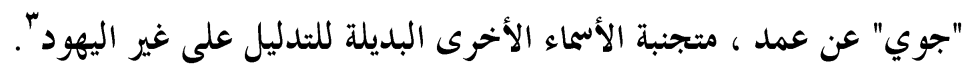
ولذلك يدعو اليهود كل من هو غير يهودي الذين يعيشون وسطهم هجذا الاسم ، ويقولون إن

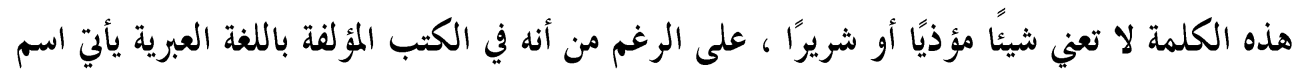
"جوي" بكعنى فاسدء

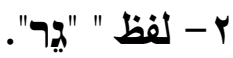

هو لفظ من الألفاظ التي تطلق على غير اليهود ،و هو مشتق من الفعل " هائح " بمعنى سكن او قطن .

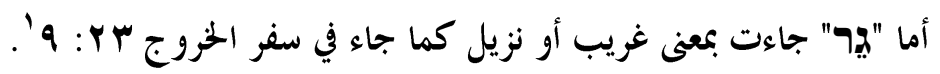

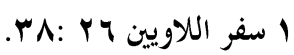
r الفكر العقدي اليهودي ، أهم أسس الديانة اليهودية وعناصرها ومقدساتًا - د سامي الإمام - جامعة الأزهر كلية اللغات والترجمة - قسم اللغة العبرية ، ص (ب ـ ( ).

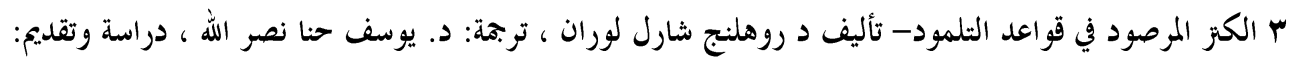

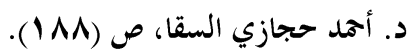

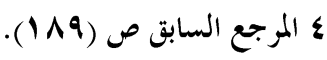




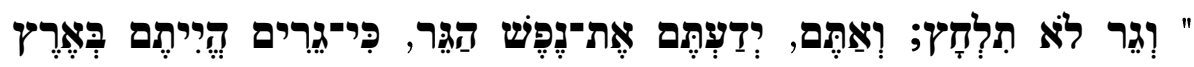

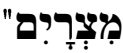

" لا تضايق الغريب فإنكم عارفون نفس الغريب ، لأنكم كنتم غرباء في أرض مصر".

$$
\text { وأيضا جاء لفظ " هيר " بعنى الغريب في سفر أيوب". }
$$

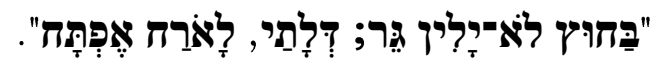

" غريب لم يبت في الخارج. تفتح للمسافر أبوابي".

كما أن لفظ " هيר " استخدمت بعمنى المتهود أو الغريب الذي اعتنق الديانة اليهودية في زمن

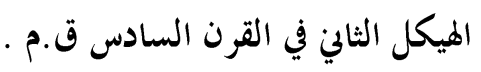

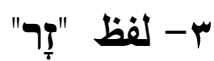

جاء اللفظ "جّه" بعمنى الآخر أو ليس قريبًا أي بعيدًا ، أو ليس ذا شأن كما جاء في سفر الملوك

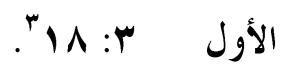

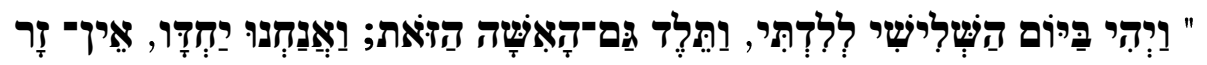

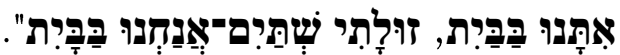

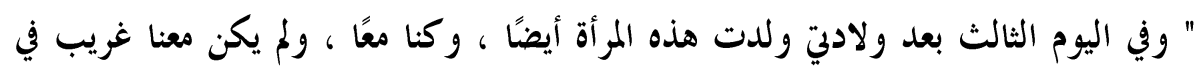

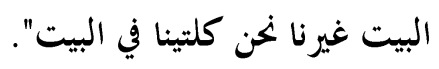

و وجاء مصطلح " זِר " بمعنى غريب من شعب آخر ، أو من أرض أخرى كما جاء في مراثي

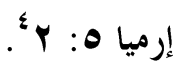

ו המלון החדש - אברהם אבץ שושן ע"מש( וץץ).

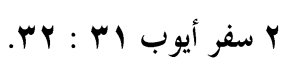

r המלון החדש - אברהם אבן שושן עמ (790). ؛ המלון החדש - אברהם אבן שושן עמ (790). 


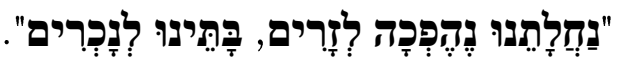 \\ " قد صار ميراثنا للغرباء. بيوتنا للأجانب".}

كما أن مصطلح " זְר " جاء في سفر العدد V I : ه للدلالة على من هو ليس بكاهن' .

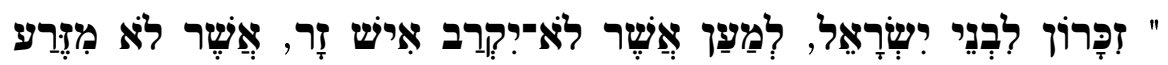

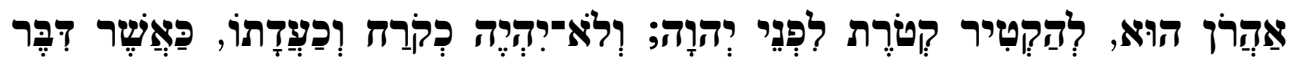

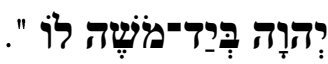

" تذكار لبني إسرائل ، لكي لا يقترب رجل أجنبي ليس من نسل هارون ليبخر بخورًا أمام

$$
\text { الرب، فيكون مثل قورح و جماعته ، كما كلمه الرب على يد موسى". }
$$

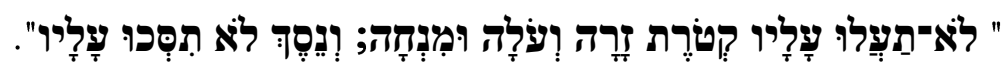

" لا تصعدوا عليه بكورًا غريبًا ولا محرقة أو تقدمة ، ولا تسكبوا عليه سكيبًا ".

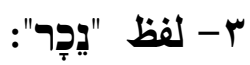

من الفعل " بِدِِר" بمعنى غرب ،أو هجر، و جعله غريبًا ، أبعد.

أما "وِجָר" بعمنى غريب ، أمر غريب أو بيئة أجنبية ( غريبه) كما جاء في سفر نحميا با: r.

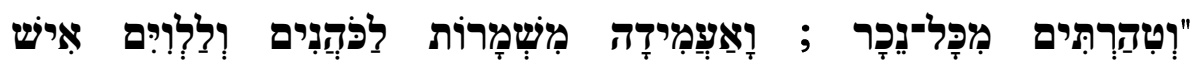

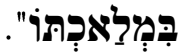

" فطهرقم من كل غريب ، و أقمت حراسات الكهنة واللاويين ، كل و احد على عمله".

$$
\text { r المرجع السابق (790). }
$$
r המלון החדש - אברהם אבן שושן ע"מ (צעד (1). 
كما أفا جاءت للدلالة على آلهة الشعوب الأخرى أو الأجنبية كما جاءت في سفر الثنية اب:

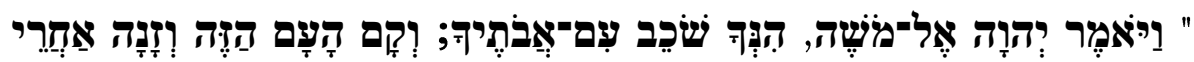

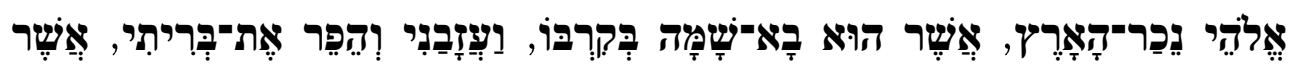

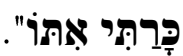

" وقال الرب لموسى" ها أنت ترقد مع آبائك ، فيقوم هذا الشعب ويفجر وراء آلة الأجنبين

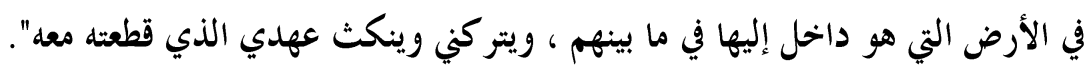

واستخدم لفظ "يَجِר" للدلالة أيضًا على غير اليهودي ، أو من شعب أخر غير شعب بني

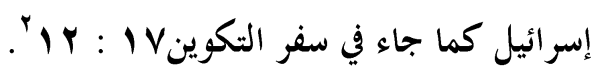

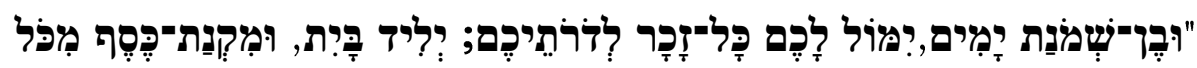

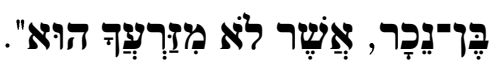

" وابن ثمانية أيام يختن منكم كل ذكر في أجيالكم : وليد البيت، والمبتاع بفضة من كل ابن

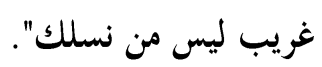

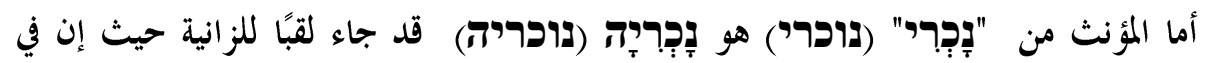

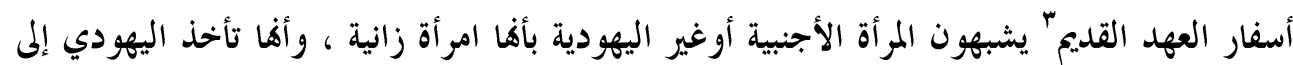

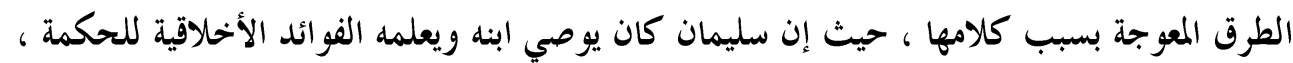

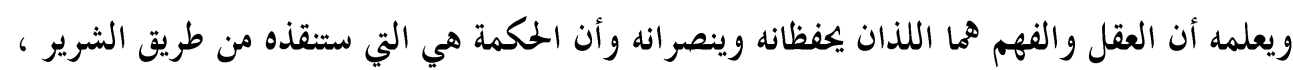
و كذلك ستجنبه الإنسان المتكلم بالأكاذيب؛ و ولعمل

ו המלון החדש - אברהם אבץ שושן עמ (צעד (1).

$$
\begin{aligned}
& \text { r المرجع السابق. } \\
& \text { با المرجع السابق. } \\
& \text { ع سفر الأمثال الإصحاح الثاني. }
\end{aligned}
$$




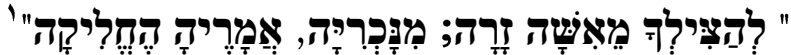

" لأنقاذك من المرأة الأجنبية ، من الغريبة المتملقة بكلامها".

و كل هذه المسميات تعد كاسم واحد للدلالة على كل من هو غير اليهودي، كما أن الغريب

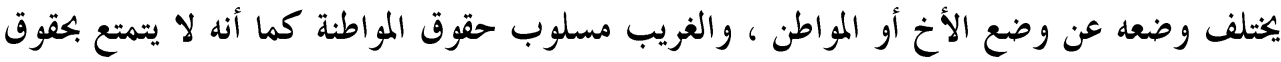

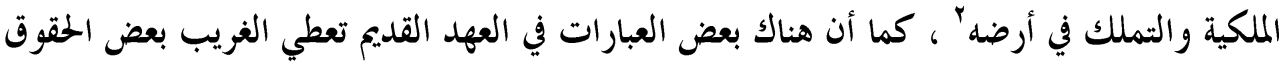
القليلة جدًا التي لا تفيد فغير اليهودي يعامل كمواطن من الدرجة الثالثة. ثانياً: التمييز في المعاملات الاجتماعية:

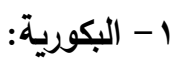

و كذلك أيضًا نجد أن الشريعة اليهودية قتم بالابن البكر وتعده خليفة أبيه في كل شئ ،

ويكون هو المتصرف في كل شئون أبيه ، وينص الفقه اليهودي على أن الابن البكر له ضعف ما يكون اليكون

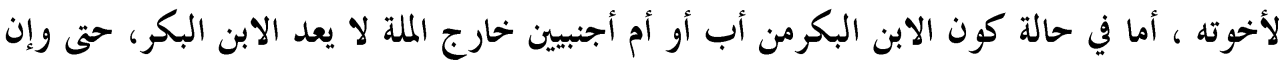

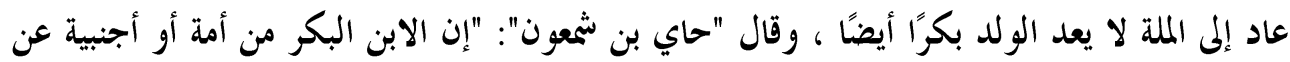

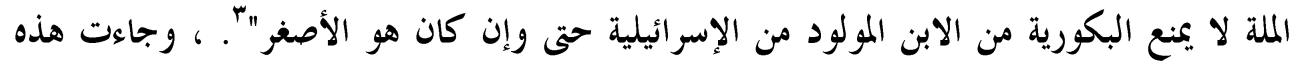

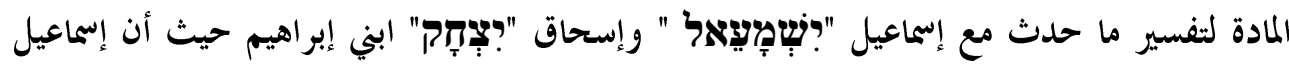

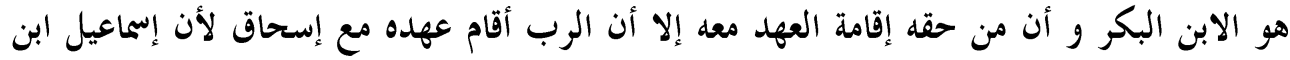

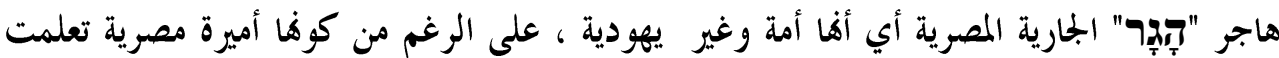

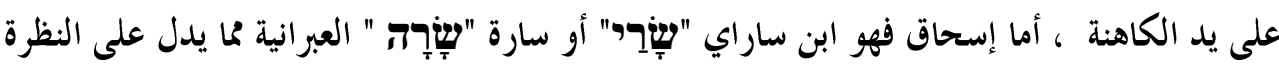

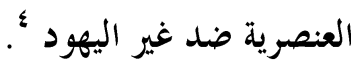

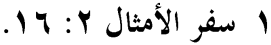

r الفكر العقدي اليهودي ستأليف د سامي الإمام ص (T Y I). r الفكر الديني الإسر ائيلي ومذاهبه - د حسن ظاظا (قسم البحوث والدراسات الفلسطينية) - IVVI ل، ص (דبr، 


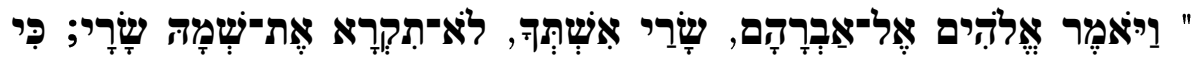

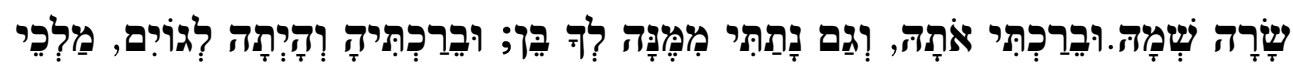

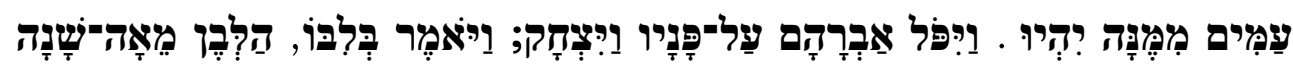

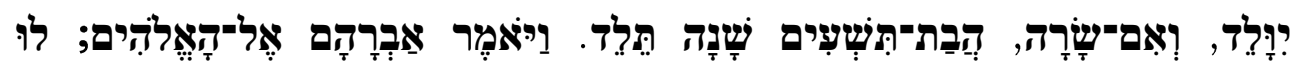

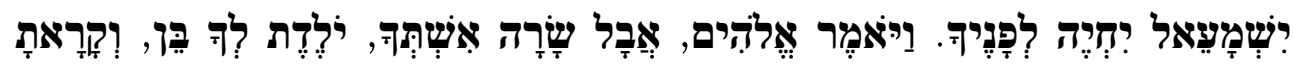

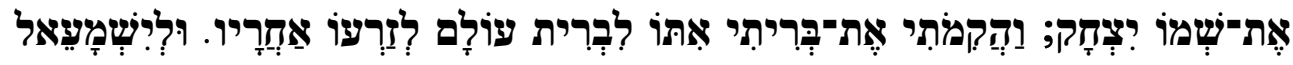

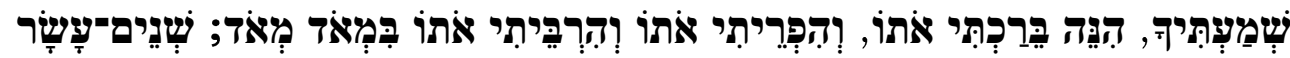

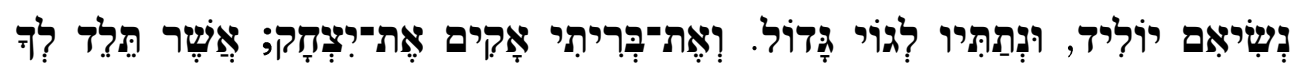

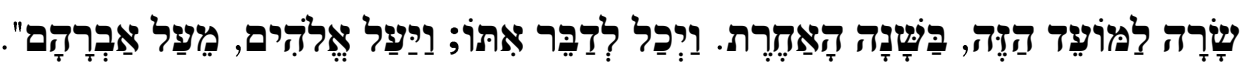
" وقال الله لإبراهيم : " ساراي امرأتك لا تدعو اسمها ساراي ، بل اسمها سارة. وأباركها

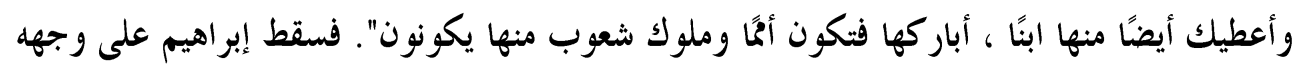
وضحك، وقال في قلبه" هل يولد لابن مئة سنة؟ وهل تلد سارة وهي بنت تسعين سنة؟". وقال إبر اهيم اللة:" ليت إسماعيل يعيش أمامك". فقال الله:" بل سارة امرأتك تلد لك ابنًا وتداعو اسمه إسحاق، وأقيم

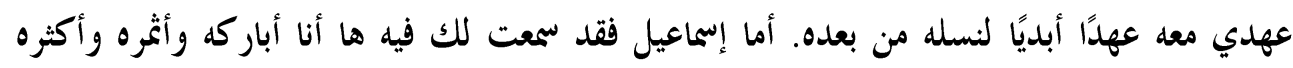

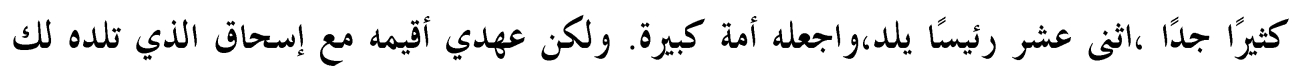

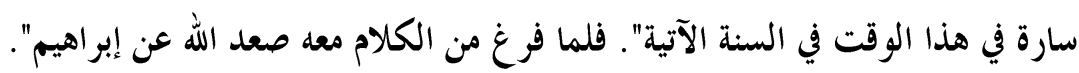
فنلاحظ هنا أن حق إسماعيل في البكورية أو حقه في إقامة العهد معه ضاع لأنه من أم أجنبية مما

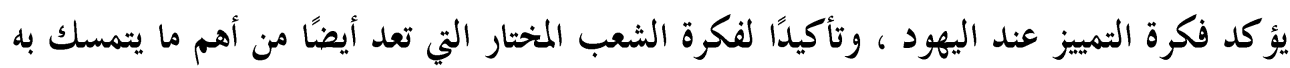
اليهود ويجعلهم يفرقون في المعاملة بينهم وبين غيرهم من غير اليهود.

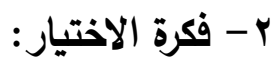
إن فكرة "الاختيار" من الأفكار الراسخة في عقول اليهود وكيف أن الرب اختارهم دون

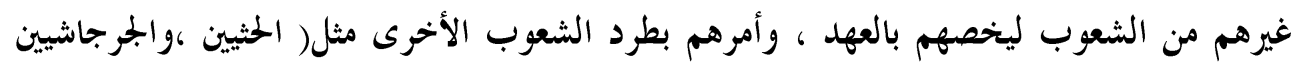

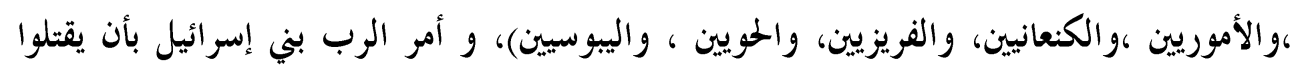

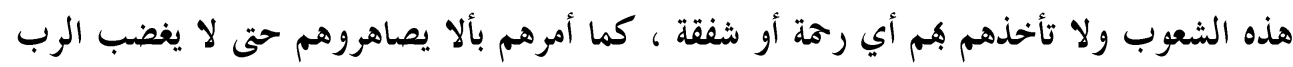


ويهلكهم ، ولكن ما يفعلونه هو هدم مذابكهم ، وكسر أصنامهم، ويحرقون تماثيلهم بالنار' . وكل

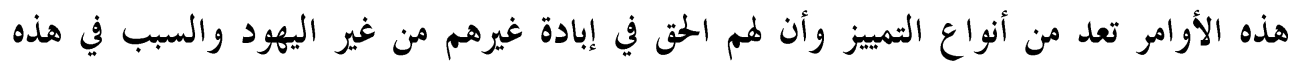

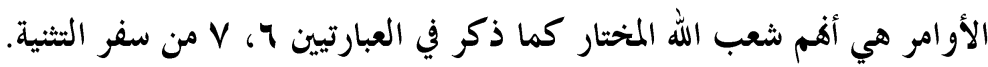

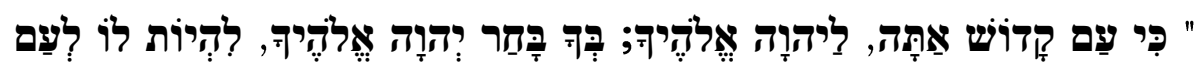

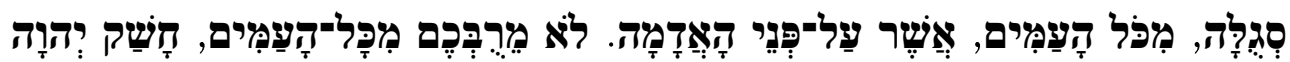

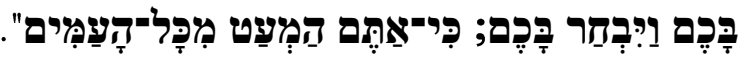

" لأنك أنت شعب مقدس للرب إلهك. إياك قد اختار الرب إلهك لتكون له شعبًا أخص من

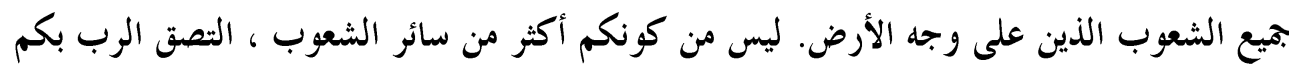

$$
\text { واختار كم، لأنكم أقل من سائر الشعوب". }
$$

فاليهود يوون أنفسهم مكلفيين بأداء أعمال ومسوؤ ليات خاصة بهم مثل إقامة دولة يهودية عادلة تقوم على عبادة الرب على الرغم من أن هذه الأعمال بجرد إدعاء فقط لاقامة دولة خاصة

كما أن العلامة "لازار" قال في كتابة اللاسامية : " إن إسرائيل هو الشعب المختار وهو القيم

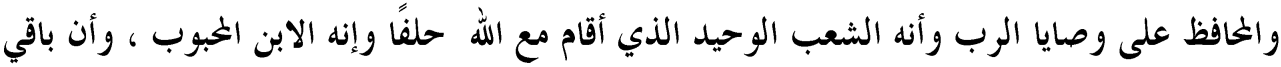
الشعوب أقل مرتبة من اليهود في نظر العالم".

ويرى اليهود أن الفرق بين اليهود وغيرهم هو الفرق بين الإنسان والحيوان ، وينظر اليهود إلى

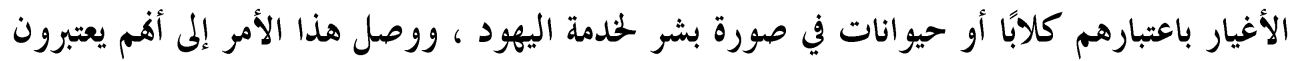

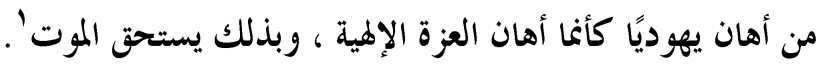

ا سفر التثنية V:

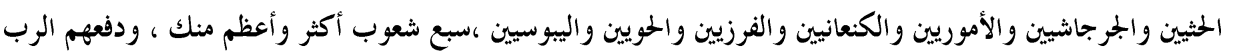

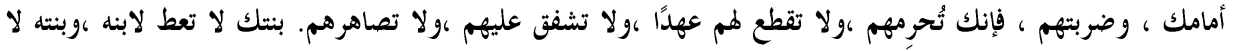

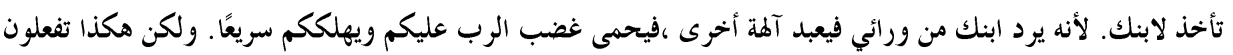

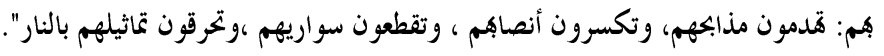

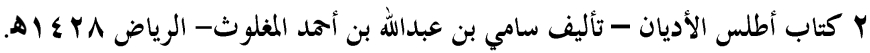


مما يوضح مدى كره اليهود لغيرهم من الشعوب الأخرى والتمييز بينهم وبين غيرهم على

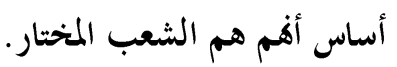

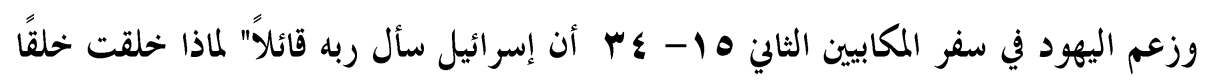

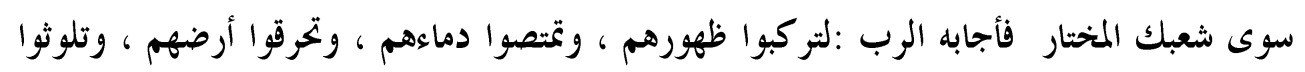

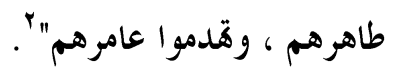

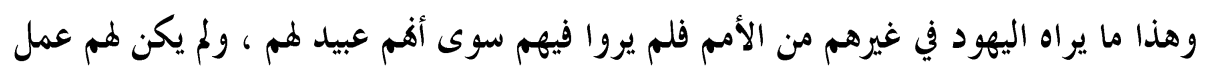

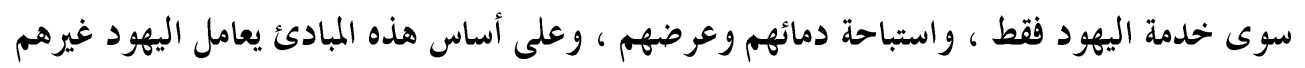

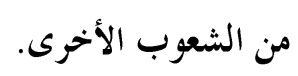

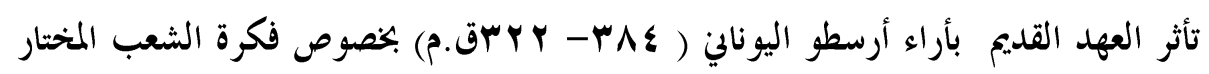

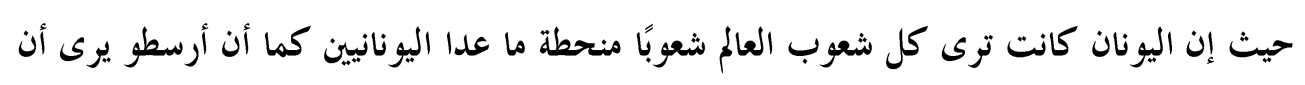

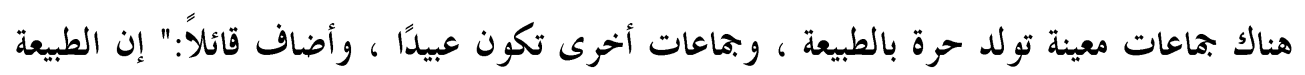

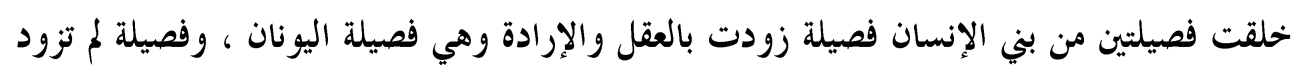

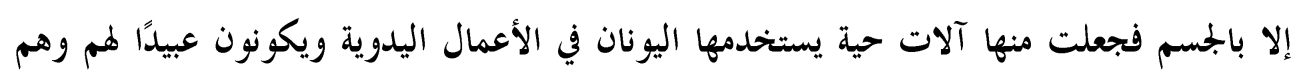

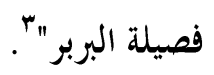

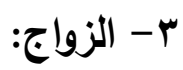

من الموضوعات المهمة التي تظهر فيها العنصرية هو "الزواج" حيث إن أنبياء بني إسرائيل كانوا

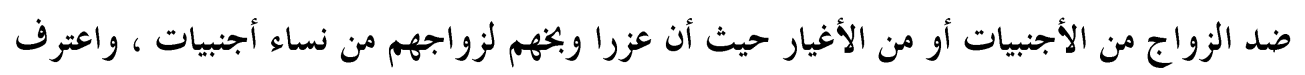

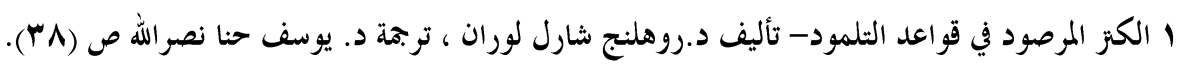

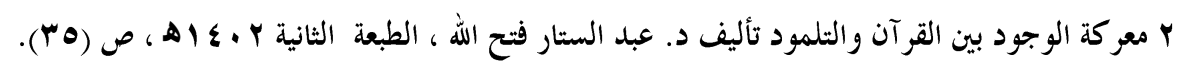

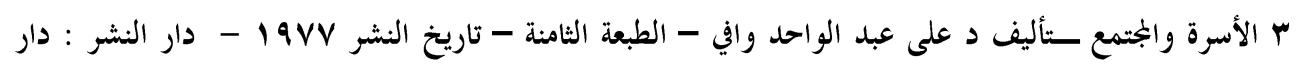

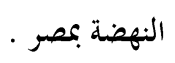


الشعب بهذا الخطأ وطردوا نساءهم وأولادهم ، واستحلف عزرا كلاًّ من الكهنة واللاويين ألا يعودوا

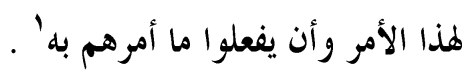

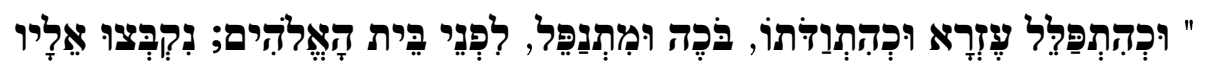

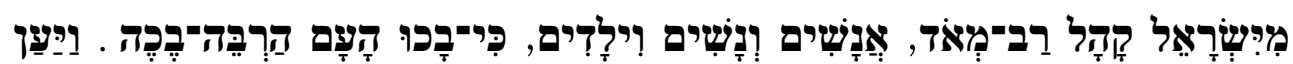

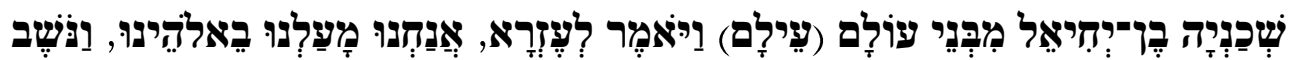

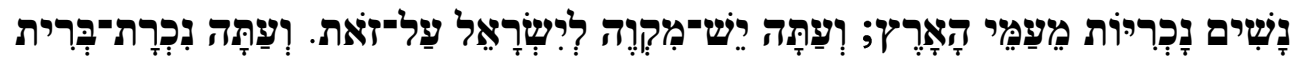

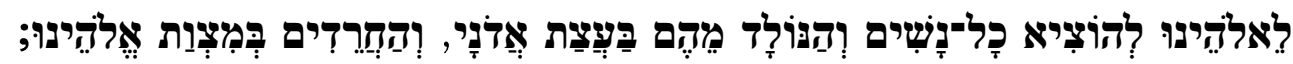

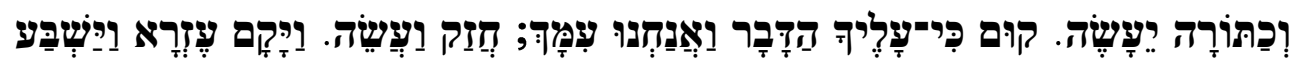

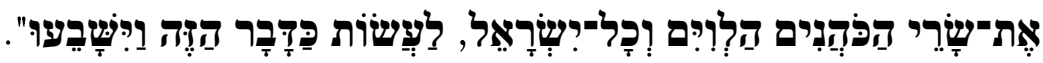
" فلما صلى عزرا واعترف وهو باكٍ وساقط أمام بيت الرب ، اجتمع إليه من إسرائيل بماعة

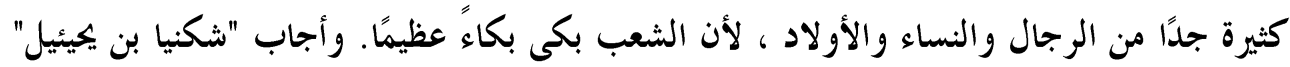

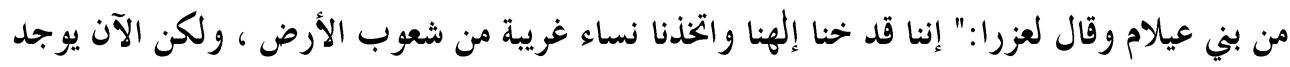

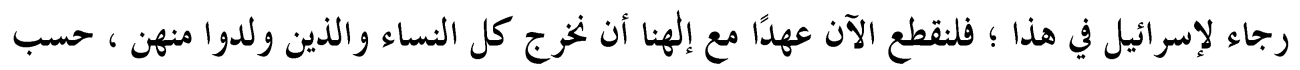

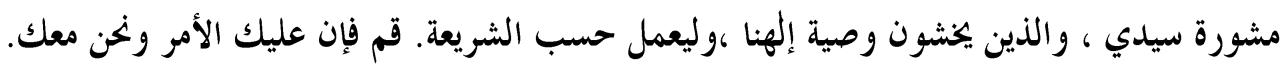

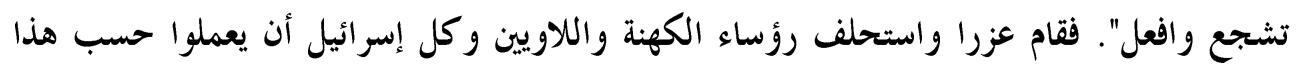

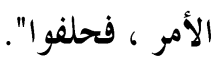

فنلاحظ أن الرب حرم ، و منع اليهود الزواج من الشعوب الأخرى ، فالزواج المختلط غير

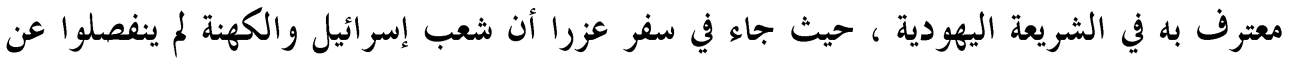

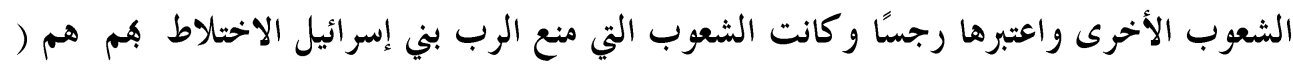

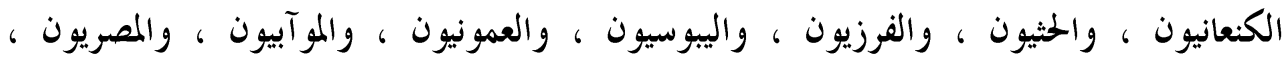
والأموريون). حيث إفم اعتبروها اختلاط الزرع المقدس بشعوب الأراضي ، ويعد هذا الأمر بمثابة

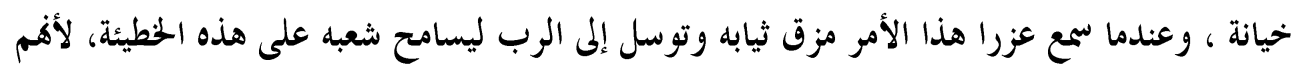


شعوب نجسة، كما أمرهم بألا يتخذوا بناتم لابنائهم ، وبألا يحرصوا على سلامة هذه الشعوب

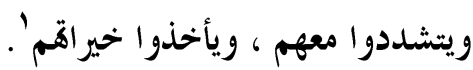

فمن علامات العنصرية وصف الشعوب الأخرى بأفم شعوب نجسة ، ونجاساقم تملأ الأرض ،

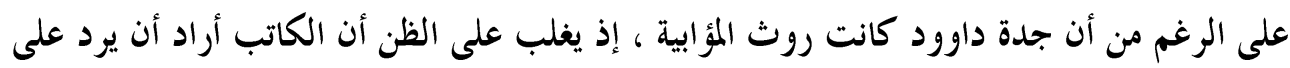

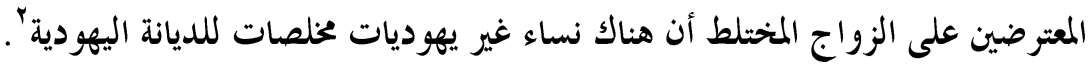

ثالثًا: المعاملات الاقتصادية :

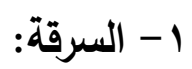

جاء تحريم السرقة ضمن وصايا الرب العشر التي أعطاها يهوة لموسى في سفر الحروج ·r:

وعلى الرغم من أن الوصايا العشر التي يعتقد اليهود أفها كلمات الرب لموسى فإنها لا تطبق إلا

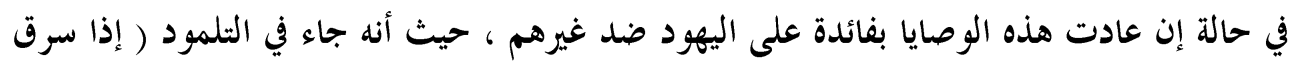

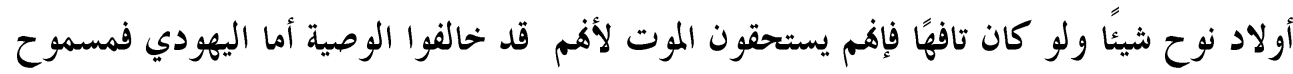

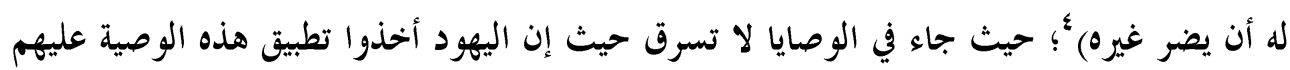

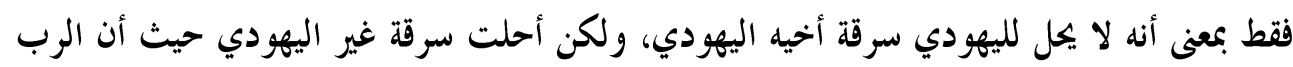

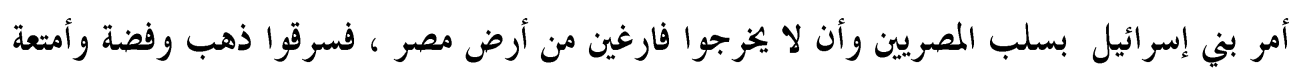
المصريين.

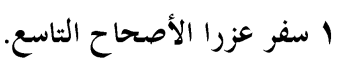

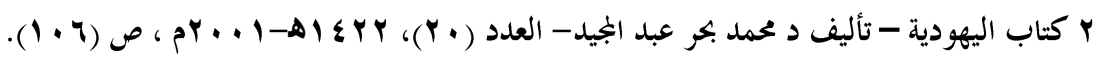

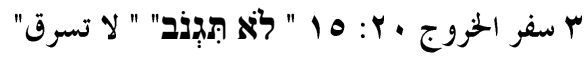

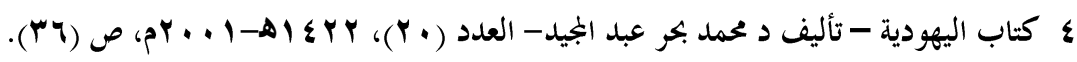

$$
\begin{aligned}
& \text { ه سفر الخروج r: الب، Y Y. }
\end{aligned}
$$




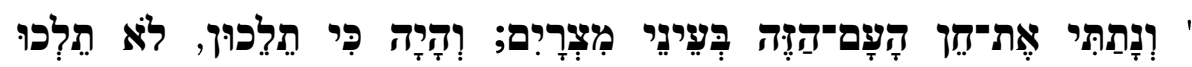

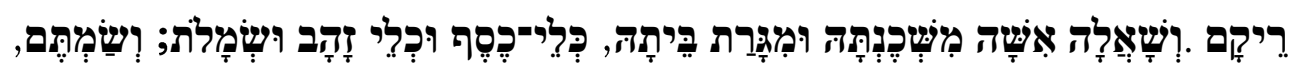

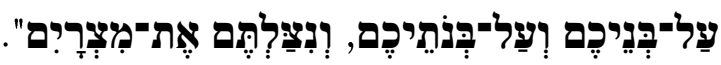
" وأعطي نعمة هذا الشعب في عيون المصريين ، فيكون حينما تمضون أنكم لا تمضون فارغين.

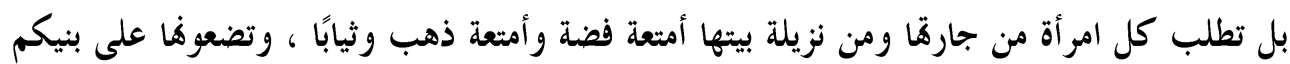

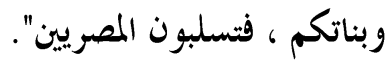

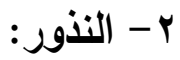

وجاء أيضًا في العهد القديم أنه إذا نذر شخص نذرًا أو نافلة ففي حالة شراء الرجل اليهودي

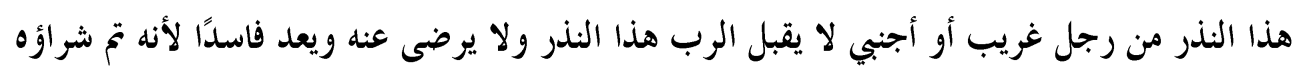

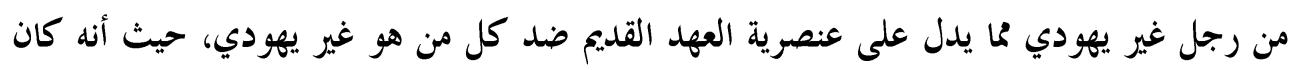

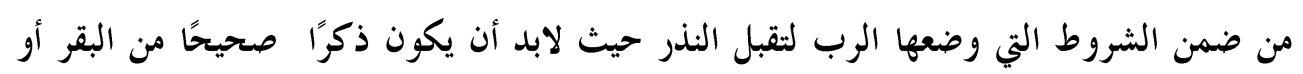

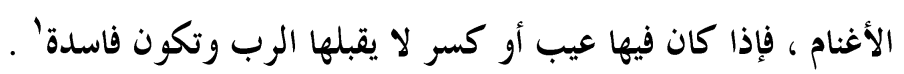

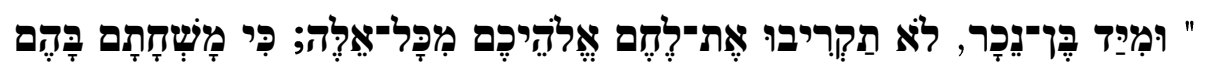

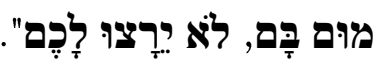

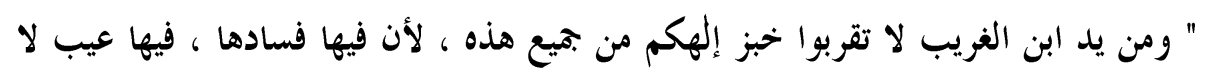

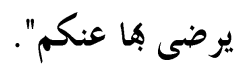

وجاء في سفر الثنية ما يدل على مدى كراهية اليهود لغيرهم حيث إن الرب في بني إسرائيل

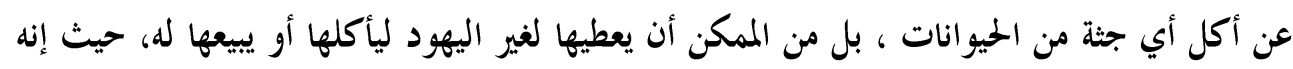

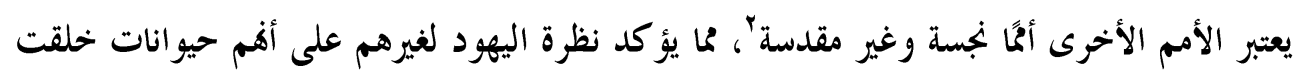
على هيئة بشر لكي تصلح لخدمتهم فقط.

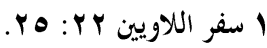

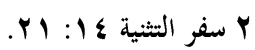


وجاء تأكيدًا لهذا الأمر في التلمود أن أحد الحماخامات الكبار ويدعى الرابي "صموئيل صرح " آلئ

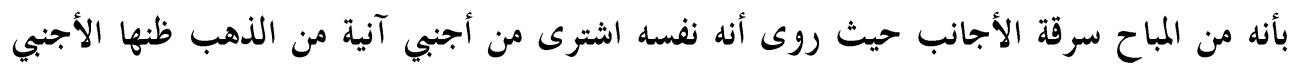

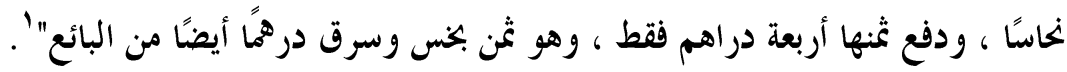
وهذا يثبت التمييز الواقع ضد غير اليهود لدرجة أن رجال دينهم يحرضوفم على سرقة الأغيار بل يعتبروها نوغًا من أنواع الإيمان.

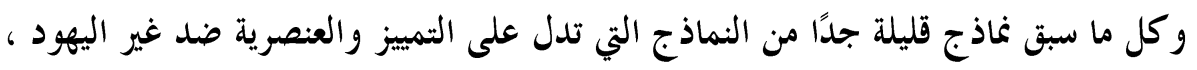

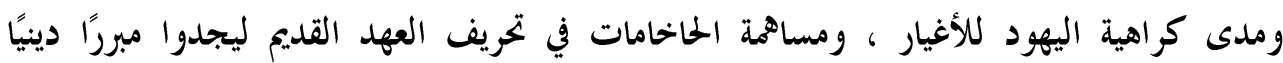

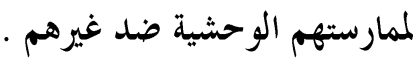

ا الكز المرصود في قواعد التلمود-تأليف د روهلنج شارل لوران- تربمة ديوسف حنا نصراللا. ص (بـ ا). VY 